\title{
Research Program at Maxey Flats and Consideration of Other Shallow Land Burial Sites
}

Prepared by Pacific Northwest Laboratory Brookhaven National Laboratory Dames \& Moore Los Alamos Scientific Laboratory New York State Geological Survey University of Arizona University of California, Berkeley University of California, Los Angeles United States Geological Survey

Pacific Northwest Laboratory

Operated by

Battelle Memorial Institute

- Prepared for

U.S. Nuclear Regulatory

Commission 


\section{NOTICE}

This report was prepared as an account of work sponsored by an agency of the United States Government. Neither the United States Government nor any agency thereof, or any of their employees, makes any warranty, expressed or implied, or assumes any legal liability or responsibility for any third party's use, or the results of such use, of any information, apparatus product or process disclosed in this report, or represents that its use by such third party would not infringe privately owned rights.

U. S. Nuclear Regulatory Commission Washington, D. C. 20555

Printed copy price: $\$ 6.50$ 


\section{Research Program at Maxey Flats and Consideration of Other Shallow Land Burial Sites}

Manuscript Completed: September 1980

Date Published: March 1981

\section{Prepared by}

Pacific Northwest Laboratory

Brookhaven National Laboratory

Dames \& Moore

Los Alamos Scientific Laboratory

New York State Geological Survey

University of Arizona

University of California, Berkeley

University of California, Los Angeles

United States Geological Survey

Pacific Northwest Laboratory

Richland, WA 99352

\section{Prepared for}

Division of Safeguards, Fuel Cycle and Environmental Research

Office of Nuclear Regulatory Research

U.S. Nuclear Regulatory Commission

Washington, D.C. 20555

NAC FIN B2380 


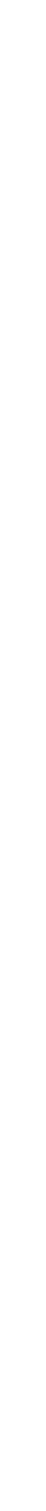

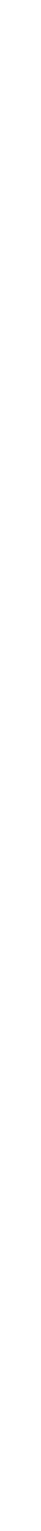




\section{ABSTRACT}

The Maxey Flats research program is a multidisciplinary, multilaboratory program with the objectives to define the radiochemical and chemical composition of leachates in the burial trenches, define the areal distribution of radionuclides on the site and the factors responsible for this distribution, define the concentrations of radionuclides in vegetation both on and offsite and the uptake of radionuclides by representative agricultural crops, define the atmospheric pathways for radionuclide transport and the mechanisms involved, determine the subsurface migration rates of radionuclides and the chemical, physical, biological, and hydrogeological factors which affect this migration, and evaluate the engineering practices which influence the seepage of surface waters into the burial trenches. The program was initiated in 1979 and a research meeting was held at the Nuclear Regulatory Commission Headquarters on July 16,1980 , to report the research findings of each of the participating laboratories and universities. Important observations from the research are included in the Summary and the results reported for each of the research efforts are sunmarized in the individual reports that are combined to form this document. 


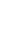

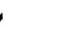




\section{SUMMARY}

\section{IMPORTANT OBSERVATIONS}

1. Waste Trench Waters

- Trench waters are complex, chemically reducing, anoxic systems. Iron exists predominantly in the ferrous state.

- Organic compounds in the trenches reflect the nature of the buried waste and the products of biodegradation.

- Complexing agents are present from chemical processing and decontamination processes.

- The distribution coefficients of several radionuclides for Maxey Flats soil and trench waters are generally lower for the anoxic conditions than for oxic conditions.

\section{Subsurface Migration}

- Subsurface migration of several radionuclides was observed.

- Subsurface migration of organic compounds has been detected in trenches and wells established to monitor radionuclide migration.

- Plutonium isotopes probably migrate in the reduced form as ionic complexes. Some of the plutonium may be complexed by ligands which have been buried or were generated in the trench.

- Subsurface migration would be expected to be a much more serious problem in areas of high rainfall than in arid regions.

3. Vegetation and Soj]

- Vegetal contamination onsite and near site appears to be very smal1. Cobalt-60 is the only radionuclide observed in vegetation which appears to exceed that from worldwide fallout.

- Surface soil samples show elevated radionuclide concentrations at several locations onsite which appear to have resulted from difficulties in site operation. 
4. Water Movement

- Water may move downward or upward through trench caps, along landfill/ sojl interfaces, and down and away from waste trenches as influenced by the hydrostatic head.

- Lateral movement of water to waste trenches appears to be small.

- Proper selection of vegetal coverage could improve removal of water by evapotranspiration.

- Inert tracer redistribution shows that water infiltrates into clay trench caps but cap tracers were not observed in trench sump water four months after completion of the experimental trench. 


\section{CONTENTS}

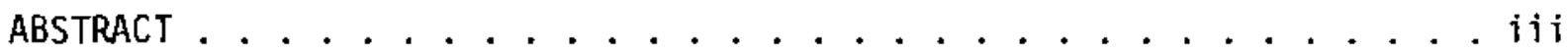

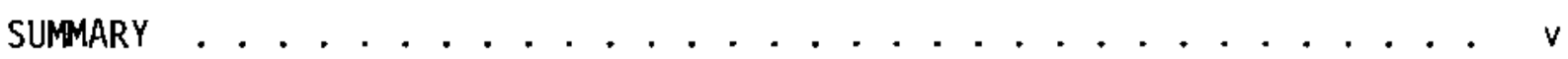

CONTENTS ................................. . . . . . . . . . . . . . . . .

FIGURES .............................. . . . xi

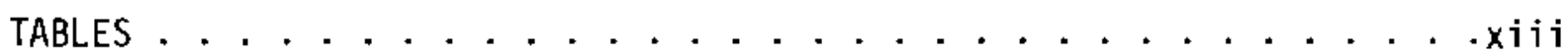

SECTION I - RESEARCH PROGRAM AT MAXEY FLATS AND CONSIDERATION. . . . . . I- 1 OF OTHER SHALLOW LAND BURIAL SITES (Pacific Northwest Laboratory)

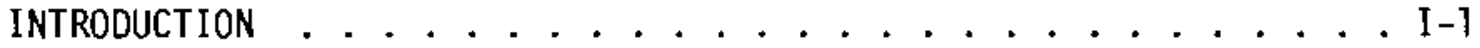

SCOPE ............................. . . I-2

RESEARCH OBJECTIVES . . . . . . . . . . . . . . . . I I 4

RESEARCH AT MAXEY FLATS . . . . . . . . . . . . . . . . . . I-5

Determination of the Radiochemical and Chemical Composition. . 1-5 of Leachates in the Burial Trenches

Areal Distribution of Radionuclides on the Site and Factors. . I-6 Responsible for This Distribution

Concentrations of Radionuclides in Vegetation, Both On and . . I-7 Offsite

Atmospheric Pathways for Radionuclide Transport and the. . . I-8 Mechanisms Involved

Determine Subsurface Migration Rates of Radionuclides and. . . I-8 the Chemical, Physical, Biological, and Hydrogeological

Factors Which Affect This Migration

Seepage of Surface Waters Into Burial Trenches and the . . . I-12 Engineering Practices Which Influence This

RESEARCH AT OTHER SHALLOW LAND BURIAL SITES . . . . . . . . . I-13

SECTION II - SUMMARY OF MAXEY FLATS RESEARCH PROGRAM (Dames \& Moore) . .II-1

SUMMARY REPORT. . . . . . . . . . . . . . . . . . . II-1

SECTION III - TRENCH WATER-SOIL CHEMISTRY AND INTERACTIONS AT THE. . . III-1

MAXEY FLATS SITE (Brookhaven National Laboratory)

SUMMARY ......................... III 


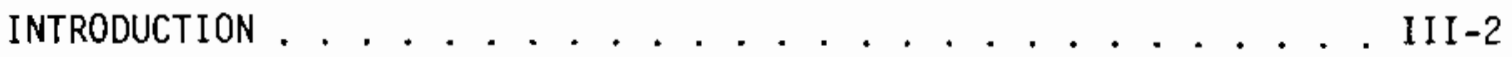

Trench Water Analysis............... III-2

Microbiological Processes............... III-3

Geochemical Considerations ............. III-3

EXPERIMENTAL APPROACH. ...................... III

RESULTS AND DISCUSSION ........................ III-6

Trench Water Analyses . . . . . . . . . III-6

Microbiological Processes . . . . . . . . . . III-11

Sorption Studies $-k_{d} \ldots \ldots \ldots$ III-12

REFERENCES . . . . . . . . . . . . . . IIII-14

SECTION IV - CHEMICAL SPECIES OF MIGRATION RADIONUCLIDES AT . . . . IV-l MAXEY FLATS AND OTHER SHALLOW LAND BURIAL SITES

(Pacific Northwest Laboratory)

INTRODUCTION ............................. IV-]

RESEARCH OBJECTIVES. ...................... IV-2

EXPERIMENTAL TRENCH ...................... IV-2

Site Selection ................... IV-3

Trench Design ............... . . IV-3

Trench Construction .............. IV-4

WATER AND SOIL SAMPLES DURING AND AFTER TRENCH CONSTRUCTION. . . . IV-5 AREAL DISTRIBUTION OF RADIONUCLIDES. . . . . . . . . IV-7 CHEMICAL SPECIES OF MIGRATING RADIONUCLIDES. . . . . . . . IV-8 CONCLUSIONS. . . . . . . . . . . . . . IV-8

SECTION $V$ - RADIOECOLOGY STUDIES AT MAXEY FLATS, KENTUCKY:. . . . . V V-1 RADIONUCLIDES IN VEGETAL SAMPLES (Pacific Northwest Laboratory) SUMMARY. .......................... $V_{-1}$

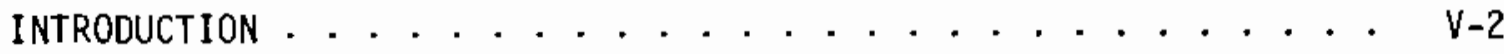




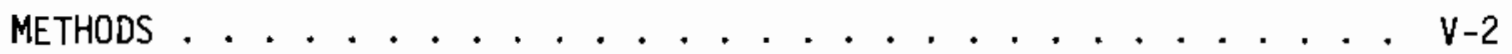

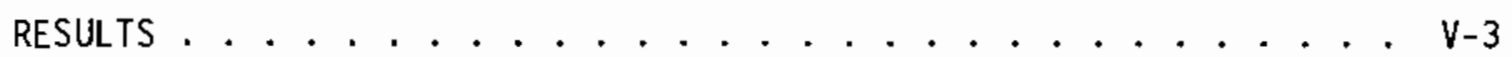

Cobalt-60.................... . . . . . .

Other Radionuclides. . . . . . . . . . . . . V-7

Pasture Grasses. . . . . . . . . . . . . . . V-8

Continuing Studies................... V-8

Food Chain Transport. . . . . . . . . . . . . V-9

SECTION VI - MIGRATION OF WASTE RADIONUCLIDES THROUGH SOILS. . . . . . VI-1 AT MAXEY FLATS, KY (Los Alamos Scientific Laboratory)

SUMMARY . . . . . . . . . . . . . . . VI -1

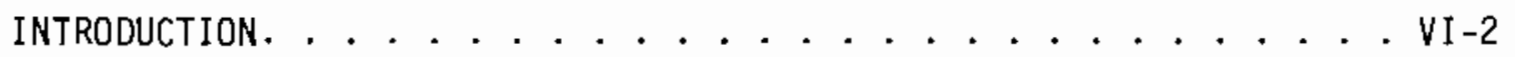

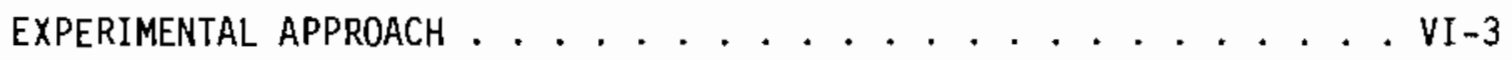

RESULTS AND DISCUSSION. .................. . . . . . .

$\mathrm{T} 4 \ldots \ldots \ldots \ldots \ldots \mathrm{VI}-3$

$195 . \ldots \ldots \ldots \ldots$. . . . . . . . . . . . . . .

FUTURE PLANS. . . . . . . . . . . . . . . VI-11

REFERENCES. .......................... VI-11

SECTION VII - STUDY OF UNSATURATED ZONE HYDROLOGY (University. . . . . VII-I of California, Berkeley)

SUMMARY ............................... . . .

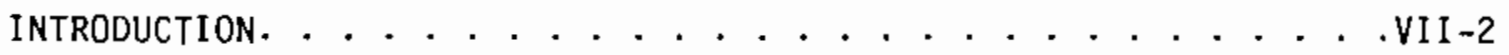

EXPERIMENTAL APPROACH .........................

RESULTS AND DISCUSSION ......................... . . . .

FURTHER WORK. . ......................... . . . . . .

SECTION VIII - THE ROLE OF VEGETATION ON SOIL MOISTURE STATUS. . . . VIII-T AND RADIONUCLIDE MOVEMENT AT MAXEY FLATS (University of

California, Los Angeles)

ABSTRACT. ............................ . . . . . . . 
$\begin{array}{ll}\text { INTRODUCTION } & \text { VIII }-2\end{array}$

$\begin{array}{ll}\text { RESULTS TO DATE VIII }-4 & \text { VII }\end{array}$

$\begin{array}{ll}\text { REFERENCES VIII }-7 & \text { VII }\end{array}$

SECTION IX - TRENCH CAP AND TRACER STUDIES (University of Arizona) IX-1

INTRODUCTION IX-1

TRENCH CAP DESIGN PARAMETERS IX-1

SAMPLING DEVICES IX-2

MONITORING RESULTS IX-3

SECTION $X$ - RESEARCH AT THE WEST VALLEY, NEW YORK LOW-LEVEL $X-1$ RADIOACTIVE WASTE BURIAL SITE (New York State Geological Survey)

SECTIDN XI - PRELIMINARY HYDROGEOLOGIC INVESTIGATION OF THE XI-1 MAXEY FLATS RADIOACTIVE WASTE BURIAL SITE, FLEMING COUNTY, KENTUCKY (U. S. Geological Survey) 


\section{FIGURES}

\section{SECTION I}

1 Maxey Flats Waste Disposal Site.... . . . . . . . . I-15

2 Sampling Installations Near Experimental Trench . . . . . . I-16

3 Plan View of Sampler Installations Near Waste Trench 19S . . I-17

4 Distribution of Radionuclides at Maxey Flats . . . . . . . I-18

SECTION II

1 Planimetric Map of Maxey Flats . . . . . . . . . . . II-6

2 Topographic Map of Maxey Flats . . . . . . . . . . . . II-7

3 General Map of Restricted Area--Maxey Flats Disposal Site . . II-8

4 Maxey Flats Disposal Facility Vicinity Map . . . . . . . . . II-9

\section{SECTION III}

1 Schematic Diagram of the System for Anoxic Collection . . . . III-4 of Water

2 Scheme for Partitioning Water Samples for Anaiysis . . . . . III-4

3 Acid-Base Titration Curves of Water Samples from . . . . . . III-10 Maxey Flats, Kentucky, Disposal Site, May 1978

4 Anericium-241 $K_{d}$ Sorption Coefficient Versus Time for . . . . III-10 Waters and Soils from Maxey Flats, Kentucky, Disposal

Site

\section{SECTION IV}

1 Maxey Flats Waste Disposal Site . . . . . . . . . . IV-16

2 Distribution of Radionuclides at Maxey Flats, . . . . . . . . IV-17 October, 1979

3 Distribution of Radionuclides at Maxey Flats, . . . . . . . IV-18 May, 1980

\section{SECTION $V$}

1 Locations of Plots for Vegetal Samples in the Surround- . . . V-12 ing Forest and on the Burial Ground (September 1979)

2 Beryllium-7, ${ }^{40} \mathrm{~K},{ }^{226} \mathrm{Ra}$ and ${ }^{228}$ Th Concentrations in . . . . V-13 Forest Floor Litter

3 Cesium-137, ${ }^{144} \mathrm{Ce},{ }^{125} \mathrm{Sb}$ and ${ }^{54} \mathrm{Mn}$ Concentrations in . . . . V-14 New Fallen Leaves 
4 Beryllium-7, ${ }^{40} \mathrm{~K},{ }^{226} \mathrm{Ra}$ and ${ }^{228} \mathrm{Th}$ Concentrations in .... V $\mathrm{V}-15$ New Fallen Leaves

5 Cesium-137, ${ }^{144} \mathrm{Ce},{ }^{125} \mathrm{Sb}$ and ${ }^{54} \mathrm{Mn}$ Concentrations in .... . V-16 Forest Floor Litter

6 Cobalt-60 Concentration in Forest Floor Litter and New. . . . V-17 Fallen Leaves

SECTION VI

1 Schematic Design of Porous Cup Sampling Locations . . . . . . VI-4 Near T4

2 Plan View of Present and Proposed Locations of Porous . . . . VI-5 Cup Samplers Near Trench 195

3 The Distribution of ${ }^{3} \mathrm{H}$ in Soil as a Function of Distance. . . VI-8 from Trench 195 at Various Depths from the Surface

\section{SECTION VII}

1 Profile View of Instrumented Transect Across Trench 19S . . . VII-7 and Adjacent Soil

2 Profile View of Instrumentation of the Experimental . . . . VII-8 Trench, Section T4

3 Relative Soil Moisture Content of Soil Profile at . . . . . . VII-9 Station No. 1, Adjacent to Trench 19S, at Various Dates

During Fall and Winter of 1979-1980

4 Relative Soil Moisture Profile of Trench Cap on ....... VII-10 Experimenta] Trench, Section T4, at Various Dates

During Fall and Winter of 1979-1980

\section{SECTION IX}

1 General Trench Cap Design . . . . . . . . . . . . . . IX-5

2 Schematic Representation of Trench Area (Not to Scale). . . . IX-6 with Tracer Information

3 Schematic Diagram of Sampler . . . . . . . . . . . IX-7 


\section{$\underline{\text { TABLES }}$}

\section{SECTION III}

1 Concentration of Dissolved Radionuclides in Water . . . . . . III-7 Samples Taken from Maxey Flats, Kentucky, Disposal Site

2 Organic Compounds Identified in Water Samples from. . . . . . . III-8 Maxey Flats, Kentucky, Disposal Site

3 Analysis of Trench and Well water Samples Taken from. . . . . . III-9 Maxey Flats, Kentucky (10/30-11/2/79)

4 Sorption Coefficients for Trench Water and Shale from . . . . . III-13 Maxey Flats, Kentucky, Disposal Site (Soil and Water Pretrea tment)

\section{SECTION IV}

1 Maxey Flats Experimental Trench Summary........... IV-10

2 Tritium Concentrations in Experimental Trench Water...... IV-11

3 Plutonium Concentrations in Experimental Trench Water.... IV-11

4 Strontium-90 Concentrations in Experimental Trench Water. . . . IV-12

5 Cobalt-60 and ${ }^{137} \mathrm{Cs}$ Concentrations in Experimental. ...... IV-12 Trench water

6 Soil Samples Taken Ouring Construction........... IV-13

7 Americium-241 Contents of Surface Soils ........... IV-14

8 Maxey Flats Soil Samples (10-7-70). . . . . . . . . . . IV-14

9 Chemical Species of Radionuclides in Experimental Trench. ... IV-15

10 Chemical Species of Plutonium in Experimental Trench. . . . . IV-15

\section{SECTION $\underline{V}$}

I Average Values of Radionuclides in Forest Floor Litter. . . . . V-4 and Newly Fallen Leaves, Maxey Flats, KY, 1979

2 Comparison of Radionuclide Content of Newiy Fallen. . . . . . V-5 Leaves Near and Remote from the Maxey Flats Disposal Facility

3 Radionuclide Content $\mathrm{d} / \mathrm{m} / \mathrm{g}$ of Newly Opened Tree Leaves. . . . V V-10 and Surface Soi1, April, 1980

4 Radionuclide Content $d / m / g$ Dry weight in Live Grass and . . . V V-ll New]y Fallen Tree Leaves (Averages and Range) 1979 


\section{SECTION VI}

1 Tritium in Soil water from the Upper and Lower Depths. . . . . VI-6 for Two Locations at T4

\section{SECTION VII}

1 Hydrogen-3 Concentration in Soil Solution, Station . . . . . VII-6 No. 1, Adjacent to Trench 19S. Sampled 1/15/80.

2 Hydrogen-3 Concentration in Soil Solution, Station . . . . . VII-6 No. 4, Trench 19S

3 Hydrogen-3 Concentration in Soil Solution, Station . . . . . VII-6 No. 5, Trench 19S

4 Pentafluorobenzoic Acid Tracer Concentration in Soil . . . . VII-6 Solution, Station No. 5, Trench 19S

\section{SECTION IX}

1 Maxey Flats Test Trench Results of Tracer Monitoring . . . . . IX-4 for Samples Obtained December 28, 1979 and March 19, 1980 


\section{SECTION I}

\section{RESEARCH PROGRAM AT MAXEY FLATS}

AND CONSIDERATION OF OTHER SHALLOW LAND BURIAL SITES

Pacific Northwest Laboratory

Richland, Washington 99352 
RESEARCH PROGRAM AT MAXEY FLATS

AND CONSIDERATION OF OTHER SHALLOW LAND BURIAL SITES

\author{
R. W. Perkins and L. J. Kirby \\ Pacific Northwest Laboratory \\ Richland, Washington 99352
}

\title{
INTRODUCTION
}

During the past two decades, six sites have been licensed in the United States for the cormercial shallow land burial of low-level radioactive waste. These include the West Valley, New York; Maxey Flats, Kentucky; Sheffield, Illinois; Barnwell, South Carolina; Beatty, Nevada; and Hanford, Washington sites. Commercial waste disposal began in Beatty, Nevada in 1962, and has subsequently expanded to include these six sites which are currently managed by four companies: Nuclear Engineering Company - Hanford, Beatty, and Sheffield; Dames \& Moore - Maxey Flats; Chemical Nuclear Systems - Barnwell; and Nuclear Fuel Services - West Valley. All of these sites are located on either federal or state-owned land.

The West Valley and Maxey Flats sites were closed in 1975 and 1977, respectively, due to difficulties which included seepage of water into the waste trenches at the burial sites. The Sheffield site was closed in 1979 when all of the land allocated for nuclear waste disposal was used and their request for permission to use additional land for this program was denied. Restrictions have been placed on burials that may be made at the other sites and the limited available burial capacity, coupled with growing restrictions on transportation of radioactive waste, provide a constraint for the growth of the nuclear industry.

Late in 1972 elevated levels of radioactivity were detected in the environs of the Maxey Flats site. In November 1973 the Kentucky Department for Human Resources (KDHR) initiated a six months' study to identify the source and extent of these increased levels of environmental radioactivity. From this study KDHR concluded that the Maxey Flats waste disposal site was contributing radioactivity to the environment, but that the radioactivity detected in the environment did not create a public health hazard. Subsequently, studies were undertaken by the U. S. Environmental Protection Agency (EPA) to clarify existing questions about plutonium mobility in the environment. 
The EPA studies concluded that plutonium and other radionuclides have been leached or released from the wastes and that plutonium contamination existed in and around the Maxey Flats site. Plutonium had apparently migrated from the trenches and site and suggested pathways included surface transport, interflow, subsurface movement, and atmospheric fallout. Other radionuclides measured included ${ }^{3} \mathrm{H},{ }^{60} \mathrm{Co},{ }^{89}, 90 \mathrm{Sr},{ }^{134} \mathrm{Cs}$, and ${ }^{13}{ }^{7} \mathrm{Cs}$. The evidence favored migration of the radionuclides by two or more of the water pathways, but insufficient evidence was obtained to conclude the form, quantity, and migration rate for the plutonium. The studies pointed out that deficiencies existed in the existing practices for safely containing buried radionuclides during their hazardous lifetimes.

The research program which is outlined here has the goal of defining the distribution and movement of radionuclides and the factors which affect this distribution within and adjacent to Maxey Flats and other shallow land burial sites. Radionuclide movement as a result of surface run-off, subsurface migration, and atmospheric transport will be characterized. The engineering practices which affect migration will be evaluated and some alternatives investigated. The chemical species of the migrating radionuclides will be determined, and the physical, chemical, and biological factors which produce the chemical species will be identified. The research program is expected to provide some of the basic information which is necessary to permit improvement of operating criteria at existing sites, the development of suitable procedures for decommissioning these sites, and the establishment of siting criteria for the selection of potential new sites.

\section{SCOPE}

Experience in commercial shallow land burial has resulted in the identification of several problems. Some of these are rather serious and have been responsible for the closure of some sites. From operating experience, it has become clear that those sites located in the eastern half of the country where precipitation is relatively high experience more problems than those located in the more arid western regions. At the Maxey Flats and West Valley sites, interpretation is complicated by the fact that radioactive materials could have been spread by processes other than subsurface 
transport. Maxey flats utilizes an evaporator to concentrate the radioactive material contained in leachate pumped from waste trenches. The West valley site includes the Nuclear Fuel Services fuel reprocessing plant and associated waste handling storage facilities. At both Maxey Flats and West valley (and other sites as well), the burial trench caps subsided and the reworking of these areas to form new caps has resulted in some general lowlevel contamination.

In earlier work at Maxey Flats, there were two reasonably good indications of subsurface movement of radionuclides at Maxey Flats, including the apparent movement of tritium and other radionuclides to a well which had been drilled near a waste burial trench, and the detection of radioactivity in moisture seeping through a crack in a sandstone layer near the bottom of a trench dug adjacent to a waste burial trench. Other known sources of contamination at Maxey Flats include atmospheric transport from the evaporator plume and spitlage of radioactive liquids. Consequently, it is very difficult from currently available information to differentiate in many cases between environmental contamination from surface sources and radionuclide migration by subsurface aquifers. Experience at the western sites seems to be relatively uncomplicated.

A problem which appears to exist to some degree at all the sites is the precise definition of burial trench boundaries. Monuments which have been placed to locate trenches are at times on the center line but are also placed along where the trench is believed to have been or at opposing corners of the trenches, thus making it difficult to carry out studies of migration. At one site, burial trenches were found to extend beyond the perimeter fence. Any attempt to study a specific site, therefore, requires a preliminary definition of waste trench location at that site.

From a regulatory standpoint, it is essential to have information relative to the operation and performance of shallow land burial sites to meet the following needs:

1. To determine guidelines for the operation of existing sites;

2. To develop recommendations for remedial actions at existing sites and for their eventual decommissioning; 
3. To identify the need for long-term surveillance and maintenance at the existing sites; and

4. To develop site selection criteria for future waste burial sites.

Several research programs have been initiated by the Nuclear Regulatory Commission (NRC) to meet these needs, and hydrogeological studies are also being conducted by the U.S. Geological Survey. The laboratories participating in research at Maxey Flats include Pacific Northwest Laboratory, Brookhaven National Laboratory, Los Alamos Scientific Laboratory, the University of California-Berkeley, the University of California-Los Angeles, and the University of Arizona-Tucson. Cooperating government agencies include the Kentucky Department for Natural Resources, as well as the U. S. Geological Survey, and Dames and Moore maintains an ongoing research program. The current research objectives of the laboratories and the U. S. Geological Survey are summarized below and discussed in the following sections.

\section{RESEARCH OBJECTIVES}

The Maxey Flats shallow land burial site is currently of greatest concern. However, the research objectives for Maxey Flats generally apply to all the commercial shallow land burial sites. In a broad sense, the research objectives are to generate information needed to define:

1. Radiochemical and chemical composition of leachates in the burial trenches;

2. Areal distribution of radionuclides on and adjacent to the site and the factors responsible for this distribution;

3. Concentrations of radionuclides in vegetation both on and offsite and the uptake of radionuclides by representative agricultural crops;

4. Atmospheric pathways for radionuclide transport and the mechanisms involved;

5. Subsurface migration rates of radionuclides and the chemical, physical, bjological, and the hydrogeological factors which affect this migration; and

6. The seepage of surface waters into burial trenches and the engineering practices which influence seepage. 


\section{RESEARCH AT MAXEY FLATS}

The research programs being conducted at Maxey Flats are designed to provide information which will answer the broad questions stated above. In order to more clearly follow the discussion, four figures are included in this section. Figure 1 presents a schematic of the Maxey Flats site showing the 10cation of the waste burial trenches; Figure 2 shows a layout of the experimental trench sections and monitoring wells which are planned; Figure 3 shows the installations which have been constructed on will be constructed in the vicinity of the 195 waste burial trench; and Figure 4 shows the results of areal monitoring for radionuclides on the site. The six broad areas of research and the objectives and initial results are summarized below.

1. Determination of the Radiochemical and Chemical Composition of Leachates in the Burial Trenches

It is extremely important to understand the chemistry and radiochemistry of leachates in the burial trenches. All of the burial trenches at Maxey Flats contain water which must be periodically removed to prevent upward seepage and overflow of this water. Within the burial trenches, degradation of the organic material associated with radioactive wastes takes place by anoxic bacterial processes. This degradation results in a unique composition of the leachate. The conditions are reducing and iron is contained in the ferrous state. The organic chemicals present represent those which were originally associated with the radioactive waste, together with the bacterial degradation products. Analyses of these organic constituents suggest that the degradation products will not produce complexes with the radionuclides as strong as those which have been added to the trenches with the waste. For example, analysis of the trench water has shown the presence of tributylphosphate and EDTA which could yield plutonium and americium in strong complexes which would favor their migration.

Aerobic and anaerobic, sulfate-reducing, denitrifying, and methanogenic bacteria are present in the leachate samples and are able to grow aerobically and anaerobically in trench leachate.

The major radionuclides present in the trench water include tritium and plutonium isotopes, ${ }^{241} \mathrm{Am},{ }^{90} \mathrm{Sr},{ }^{137} \mathrm{Cs},{ }^{134} \mathrm{Cs}$, and ${ }^{60} \mathrm{Co}$. Because of the 
ano:ic conditions which exist in the waste burial trench waters, it has been necessary to sample these waters under anoxic conditions to prevent changes in chemical species. The Brookhaven National Laboratory has developed successful techniques for conducting this type of sampling and for carrying out laboratory experiments under anoxic conditions. Studies of the distribution coefficients between leachate water and soil for several radionuclides have been determined. These distribution coefficients range from hundreds to more than a thousand for ${ }^{241} \mathrm{Am}$ and cesium radionuclides but are less than 10 for strontium and cobalt radionuclides.

Where ultrasonically disaggregated samples of Maxey Flats soil were used, the $k_{d}$ 's were higher under oxic vs anoxic conditions. High $k_{d}$ 's are not entirely consistent with observations of very high concentrations of americium and plutonium in water from an experimental trench which was excavated about $10 \mathrm{~m}$ from, and parallel to a waste-filled trench. This indicates that predicting radionuclide retention in a field situation is more complex than sim$p$ le consideration of $k_{d}$ results would indicate.

2. Areal Distribution of Radionuclides on the Site and Factors Responsible for This Distribution

Waste handling at commercial shallow land burial sites in general, and specifically at Maxey Flats, has resulted in some contamination of surface soils. There are particular problems at the Maxey Flats site where substantial subsidence of the trench caps occurred, as well as overflow of some of the trenches due to infiltration of rainwater. Reworking of the surface areas resulted in distribution of mildly contaminated soil over the site area. Other factors, such as waste tank leakage and leakage from trench pumping processes, have also resulted in contamination. Another source of potential contamination is from the evaporation of trench water pumped from the burial trenches to prevent their overflow.

In initial studies by Dames \& Moore, radiation mapping indicated areas onsite where soil contamination was evident. Soil sampling at these locations has shown the presence of significant amounts of ${ }^{137} \mathrm{Cs},{ }^{60} \mathrm{Co},{ }^{125} \mathrm{Sb}$, and ${ }^{238} \mathrm{Pu}$. Subsequent measurements by PNL using a high resolution gamma-ray spectrometer which viewed circular areas approximately $5 \mathrm{~m}$ in radius have shown specific radionuclide distribution over the site area and over some adjacent regions. Soil samples were also taken for radiochemical analysis 
in the laboratory and provided concentrations of plutonium isotopes, ${ }^{241} \mathrm{Am}$, and strontium. These observations are contained in a later section of this document.

3. Concentrations of Radionuclides in Vegetation, Both On and Offsite

There are minor concentrations of radionuclides in vegetation both on and offsite at Maxey Flats. This contamination could have resulted from root uptake or by foliar absorption of airborne radionuclides. It could also have resulted from worldwide fallout or contamination from the site.

To determine which of these routes is important and also gain information on how the soil which supports the vegetation becomes contaminated, an ecological study is being conducted by PNL. This work is providing a basis for differentiating between the different sources and the possible mechanisms which have resulted in an accumulation of radionuclides by vegetation. In addition, crops can be very important in controlling the moisture content at the site both in regard to runoff and evapotranspiration.

To determine the source of radioactivity on vegetation both onsite and adjacent to the site, vegetal samples were collected and analyzed for 17 radionuclides. Nine of these could be quantitatively measured by gamma-ray spectrometric analysis, and they included the four naturaliy-occurring radionuclides ${ }^{228} \mathrm{Th},{ }^{226} \mathrm{Ra},{ }^{7} \mathrm{Be}$, and ${ }^{40} \mathrm{~K}$ and the five of anthropogenic origin, ${ }^{144} \mathrm{Ce},{ }^{137} \mathrm{Cs},{ }^{125} \mathrm{Sb},{ }^{54} \mathrm{Mn}$, and ${ }^{60} \mathrm{Co}$. The concentrations of a 11 of the radioclides, except ${ }^{6} \mathrm{Co}$, fall within the same range for onsite, near-site, and remote locations. The ${ }^{60} \mathrm{Co}$ levels near the site appear to be derived from the site. From analyses of forest litter, new fallen leaves, and new green leaves, it appears that ${ }^{60} \mathrm{Co}$ enters the leaves through root uptake rather than deposition from the evaporator plume.

One of the major problems at Maxey Flats is the high precipitation rate and the infiltration of rainwater into burial trenches. Studies are being carried out by UCLA to determine if it is possible, by judicious selection of ground cover, to maximize evapotranspiration while maintaining radionuclide uptake, surface water runoff, and soil erosion at acceptable levels. For 
example, the present ground cover is estimated to permit evapotranspiration at about 11 inches per year, whereas rates as high as 28-30 inches have been obtained in similar areas by optimal vegetation coverage. In this study, five types of vegetation with good evapotranspirational properties are being investigated to determine optimal growing conditions and radionuclide uptake rates. These include both shallow and deep rooted plants. In general, the deep rooted plants can be expected to provide higher evapotranspiration; however, their radionuclide uptake must also be considered.

\section{Atmospheric Pathways for Radionuclide Transport and the Mechanisms Involved}

At the Maxey Flats site there is a special mechanism for airborne transport of radionuclides. A very substantial amount of rainwater infiltrates the burial trenches, and this is currently removed and evaporated onsite. Tritium is the predominant radionuclide in the stack effluent and represents a major fraction of the offsite releases of contamination to the site environs. The second and third most significant emissions from the evaporator, based on studies by Dames and Moore in 1979, are ${ }^{137} \mathrm{Cs}$ and ${ }^{90} \mathrm{Sr}$, respectively. Cobalt-60 and ${ }^{238} \mathrm{Pu}$ were generally at very low concentrations, and ${ }^{239} \mathrm{Pu}$ was not detectable in those samples. Recent sampling of the evaporator plume by PNL confirmed the Dames and Moore observation that the radionuclide concentrations in evaporator condensate are quite variable and probably sensitive to time of sampling and method of sampling.

The amount of entrainment in the evaporator plume needs to be very carefully compared with offsite measurements of soil to determine the precise relationship between the evaporator and onsite and offsite radionuclide concentrations.

\section{Determine Subsurface Migration Rates of Radionuclides and the Chemical, Physical, Biological, and Hydrogeological Factors Which Affect This Migration}

The Maxey Flats waste disposal site is located on an isolated plateau of weathered shale which overlies a thick sandstone marker bed. The shale is highly fractured and irregular cracks traverse the sandstone, which is nominally 7-8 m below ground surface. The groundwater system is probably 
unconfined and infiltrating rainfall is temporarily stored in weathered rock on the hilltops and colluvium and soil on the hillsides. Recharge occurs by infiltration of rainfall into the mantle and vertical unsaturated flow from the top of the hill to saturated zones below. Discharge occurs by lateral flow from the mantle and bedrock. The recharge mechanism is responsible for the accumulation of water in the waste-filled trenches and unsaturated vertical flow and lateral flow from the mantle are highly suspect as mechanisms for radionuclide migration.

The subsurface migration of radionuclides could present problems of particular concern and is therefore being given a major emphas is in our research. In order to estimate the amount of transport of radionuclides by this mechanism, a multi-disciplinary and multi-laboratory experimental trench study was initiated at Maxey Flats in the fall of 1979. Pacific Northwest Laboratory is coordinating the experiment, which incorporates research on the chemical species of migrating radionuclides, saturated and unsaturated zone hydrology and the effects of radionuclide migration, nonradioactive tracer studies to evaluate trench capping techniques, trench cap drainage systems, and vegetal covering of trench caps as a method for discouraging the infiltration of water into the trenches. The experimental trench area is shown in Figure 2.

In this work several short trenches were dug parallel to and approximately $10 \mathrm{~m}$ from one of the waste burial trenches. These trenches are equipped with sumps which permit direct sampling of seepage into the trench and porous cups and soil moisture cells at various depths which permit unsaturated flow measurements. Tracers have been added to the trench, trench cap, and adjacent soil to permit infiltration rates of surface waters to be estimated. Initial studies have indicated rather significant migration rates to these monitoring trenches from the burial trenches; the chemical and physical forms of the migrating species are being investigated. Studies of subterranean flow are also being conducted near waste-filled trench $19 \mathrm{~S}$. This will allow comparison of the characteristics of old and new trench caps with respect to water infiltration and radionuclide migration.

Initial measurements of the radionuclides in inflow water to the experimental trench sections showed concentrations that were comparable to those in 
the adjacent waste burial trench. This was true for tritium and plutonium isotopes, ${ }^{24 I} \mathrm{Am},{ }^{137} \mathrm{Cs}$, and ${ }^{90} \mathrm{Sr}$. After completion of the experimental trench, samples taken through sumps which reached to the bottoms of the trenches showed substantially lower concentrations of all the radionuclides except tritium.

We have concluded from these observations that the crushed rock added to the experimental trench may serve as an adsorption material for the radionuclides. The construction of a set of inert atmosphere monitoring wells on the waste trench burial side and the opposite side of the experimental trenches should allow the radionuclide concentrations in the soil solutions to be measured and the effects of the experimental trench to be determined.

An interesting observation in connection with inflow to the experimental trench was that the plutonium is mainiy in an anionic form and that it appears to be present as a very strong complex. A complex of the strength of EDTA could account for the characteristics of the plutonium species. The plutonium was shown to be in the reduced form existing both in the tri-and tetravalent states. Experiments are continuing to define both the actual strength and the chemical form of the plutonium.

The Los Alamos Scientific Laboratory (LASL) and the Department of Soils and Plant Nutrition of the University of California, Berkeley (UCB) in a cooperative project are studying the movement of water into trenches and water and radionuclide movement out of trenches as influenced by precipitation, soil, and vegetation in the shallow radioactive waste burial site at Maxey Flats.

LASL's efforts include the evaluation of the distribution of waste radionuclides in soit near shallow waste burial trenches with respect to seasonal changes in soil moisture movement and waste/soil interactions. Porous cups were implanted in the soil near section 4 of the experimental trench (T4) and near waste burial trench 19S. Those porous cups allow the in situ sampling on a seasonal basis of soil solutions at various depths and distances from those trenches. 
The distribution of ${ }^{3} \mathrm{H}$ suggested several patterns of water movement in the soil environment. Water may move 1) along a porous zone such as an old landfill/original soil interface, 2) from the soil surface downward and toward the burjal trench at the shallower depths, and 3) down and away from the trench at the deeper depths, as influenced by the hydrostatic head in the trench.

The distribution of radionuclides other than ${ }^{3} \mathrm{H}$ indicates interactions with soil such that migration is inhibited with respect to the movement of water. The degree of interaction differs with the different radionuclides. Cesium-137 was not detected in any of the soil solutions. Plutonium-238 and ${ }^{60} \mathrm{Co}$ were detected at the lower depths within a distance of $3 \mathrm{~m}$ (10 feet) of 195 .

Additional porous cups will be implanted to a depth of about $8 \mathrm{~m}$ (25 feet) in order to evaluate water and radionuclide migration in soil near the base of burial trenches. Detailed characterization of soil solutions will be made where significant concentrations of waste radionuclides exist.

The University of California, Berkeley, is studying the pathways of water entry through trench caps or through the soil profi\}e in the rows between the trenches, to jdentify the more important modes of water entry. The study is being carried out by implantation of soil moisture sensors at various depths in the trench caps and in the soil profiles adjacent to the trenches to enable determination of soil moisture gradients. Mini-porous cups have been installed in a paired fashion with the moisture cells to allow extraction of soil solution samples. The samples are analyzed for ${ }^{3} \mathrm{H}$, a useful hydrologic tracer due to the high ${ }^{3} \mathrm{H}$ concentration in the trenches. Pentafluorobenzoic acid has been sprayed on the soil surface and is also used as a hydrologic tracer.

To date, it has been found that the cap on trench 195 is quite permeable to water. Rainwater readily passed through the cap into the trench during the past winter. This was evidenced by both soil moisture measurements and the pentafluorobenzoic acid tracer measurements. A decreasing concentration gradient of ${ }^{3} \mathrm{H}$ from the trench water source upwards through the trench cap to the soil surface indicates water movement upwards to the surface during 
dry periods. An instrumented stack in the soil profile $10 \mathrm{~m}$ (30 feet) away from the side of the trench indicated that water was not entering trench 195 via percolation into the soil profile at this point and then lateral movement of water into the trench. Tritium data obtained at this point also indicated that trench water was not migrating outward from the trench at this location. Work on the experimental trench, section T4, indicated that the cap on this new trench prevented water from entering the trench by percolation through the cap during the winter of 1979-1980. Continuing work will encompass instrumentation of the soil profiles to deeper depths to enable a study of the hydrology at a depth near the bottom of waste burial trenches.

\section{Seepage of Surface Waters Into Burial Trenches and the Engineering Practices Which Influence This}

To determine the areas through which rainwater enters the burial trenches, tracers have been added both in cap materials and in adjacent soil of the experimental trench area. The purpose of these studies is to determine the effectiveness of the caps in retarding direct seepage into the trenches and also of the ambient soil in retarding seepage. In addition to these special experiments, it is planned that tracers will be added to one or more of the burial trenches and to monitor these tracers by sampling the water-emitting sections of the experimental trench or adjacent monitoring wells. By adding this tracer material at different locations in the burial trench, we expect to establish the rates of movement and the amounts of material being carried by subterranean flow. Trench capping studies, surface drainage studies, and the nonradioactive tracer studies are being conducted by the University of Arizona.

The trench cap design parameters provide a cap drainage system which prevents surface water seepage into the trench by providing for its quick removal by drainage and by being strong enough structurally to resist cracking when underlying materials consolidate. Soils chosen based on their 
composition characteristics were classified as practically impervious. The nonradioactive tracers incorporated in the trench construction are specific for each experimental trench section. Thus, detection of one of these tracers in any of the experimental trench sections will provide information that water is infiltrating a trench through the cap, through the adjacent soil, and possibly through horizontal movement as well. No tracer movement had been detected through the second sampling about five montins after trench construction was completed, and sampling is continuing on a quarterly frequency. RESEARCH AT OTHER SHALLOW LAND BURIAL SITES

The West Valley, New York, low-level radioactive waste burial site, like Maxey Flats, is located in a humid climate. Similar problems have been encountered at west Valley, including entry of water into the waste burial trenches and problems due to natural processes of erosion. The New York Geologic Survey is lead agency for research at west Valley to define the nature of the site, the groundwater pathways, the trenches' capacity to isolate the waste from groundwater and surface run-off patterns. Research to date indicates that the integrity of the trenches as containers is quite reasonable. Groundwater movement is vertically downward and there were no indication of substantial lateral movement of groundwater. Subtrench soil borings by USGS have indicated tritium migration to $3.2 \mathrm{~m}$ below the trench floor and $14 \mathrm{~cm}$ to $0.6 \mathrm{~m}$ below trench floor. Water entry into the trenches is the result of vertical percolation of precipitation through the capping material. Baseline geomorphic studies have been completed and investigations are underway to obtain erosion rates.

PNL has used high resolution gamma-ray spectrometry at the Beatty, Nevada, waste burial site as part of an effort to confirm the boundaries of existing waste burial trenches, locate any additional radioactive wastes beyond the established burial area, and characterize the distribution of radionuclides around the waste burial site. Cesium- $137,{ }^{60} \mathrm{Co}$, and some other radionuclides were measured around the perimeter fence and in the area where waste canisters were excavated along the northern fence. The counting data are compared with information generated by subsurface pulsed radar techniques. The highest ${ }^{137} \mathrm{Cs}$ and ${ }^{60} \mathrm{Co}$ concentrations measured slightiy beyond the 
perimeter fence were 13 and $16 \mathrm{pCi} / \mathrm{g}$, respectively. The maximum ${ }^{137} \mathrm{Cs}$ concentration measured was about 50 times the fallout concentration determined for the area near the waste burial site, but only slightly higher than fallout levels at other locations in this country. The maximum ${ }^{60} \mathrm{Co}$ concentration measured was at least 100 times the fallout concentration in the local area. Most of the ${ }^{137} \mathrm{Cs}$ concentrations measured around the perimeter fence were lower, and most of the ${ }^{60} \mathrm{Co}$ concentrations were slightly higher than common fallout levels in other parts of this country. The in situ counting measurements were compared with soil sample analyses to indicate locations of undisturbed and disturbed soils and locations where significant surface depositions of radionuclides had taken place. 


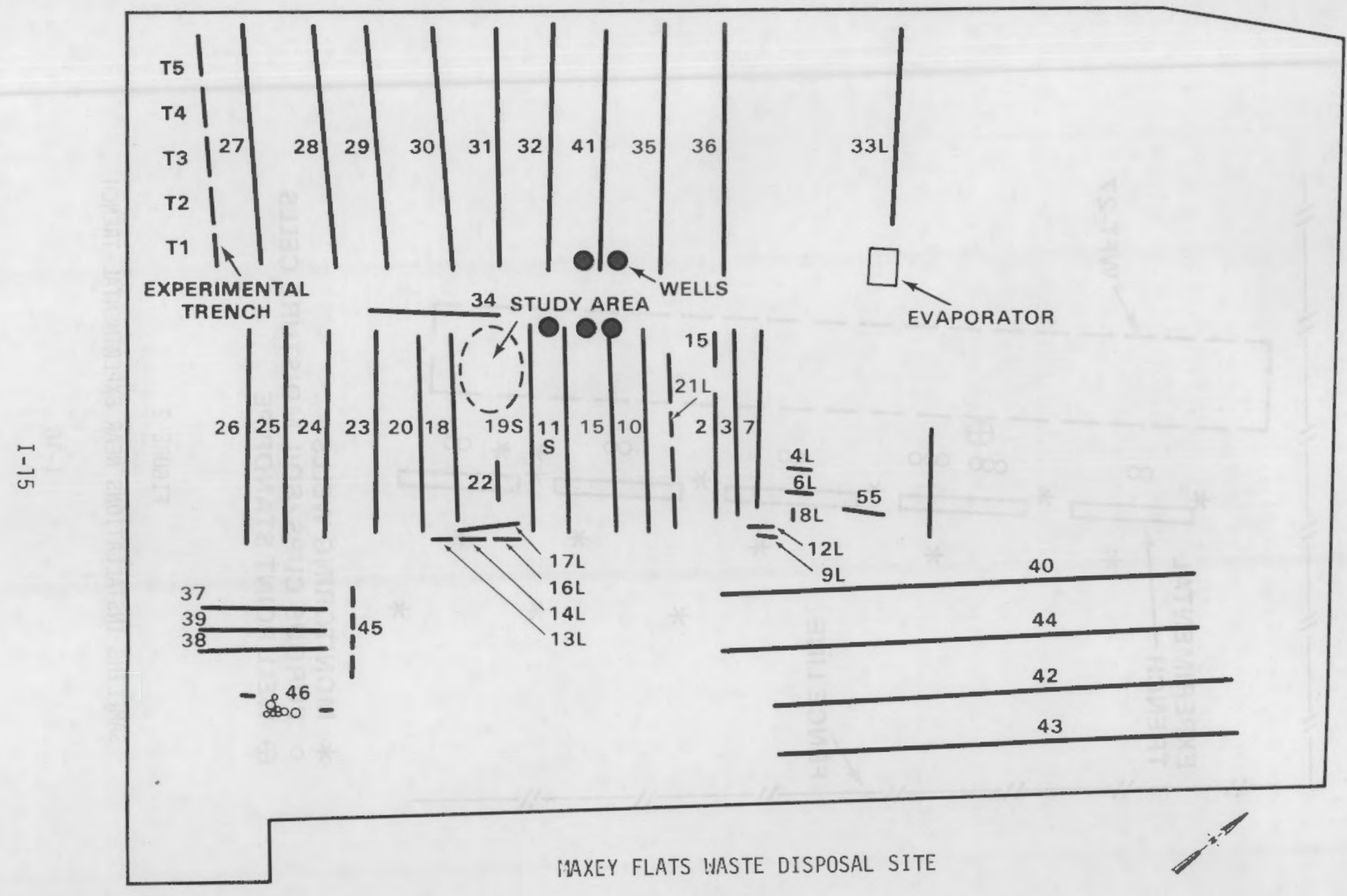

FIGURE 1 


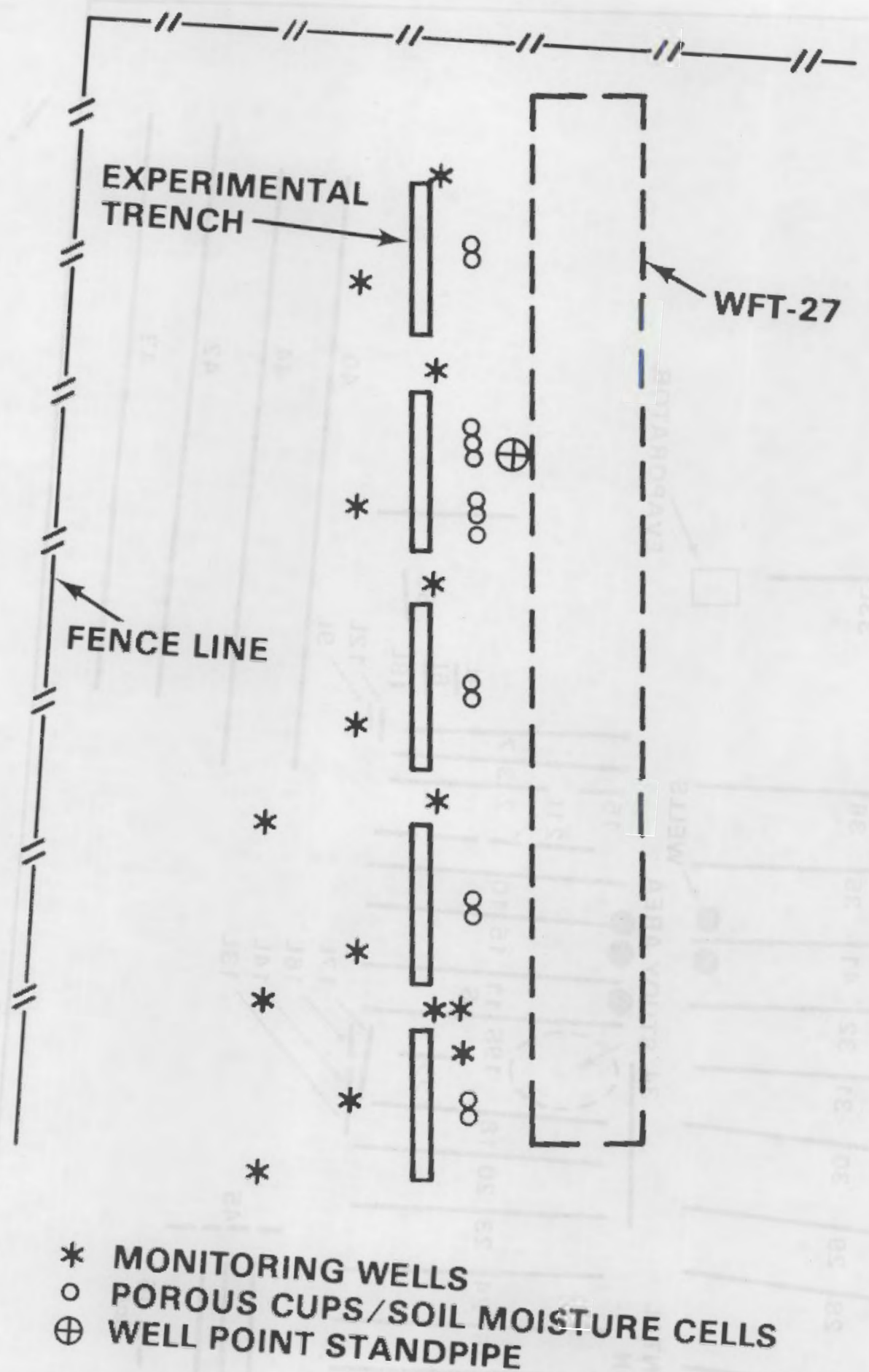

FIGURE 2

SAMPLING INSTALLATIONS NEAR EXPERIMENTAL TRENCH 


\section{PLAN VIEW OF SAMPLER INSTALLATIONS NEAR WASTE TRENCH $19 S$.}

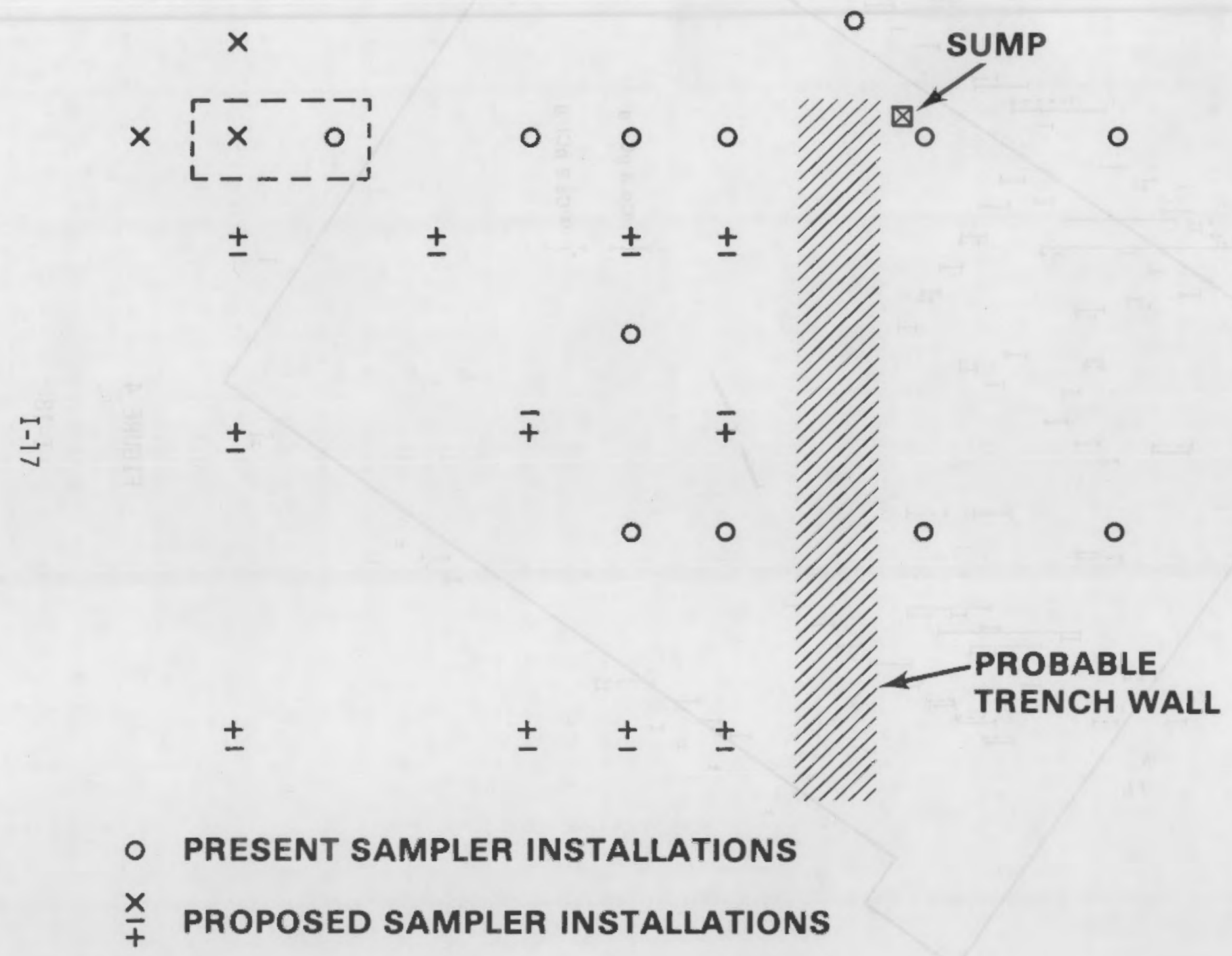

FIGURE 3 


\section{DISTRIBUTION OF RADIONUCLIDES AT \\ MAXEY FLATS}

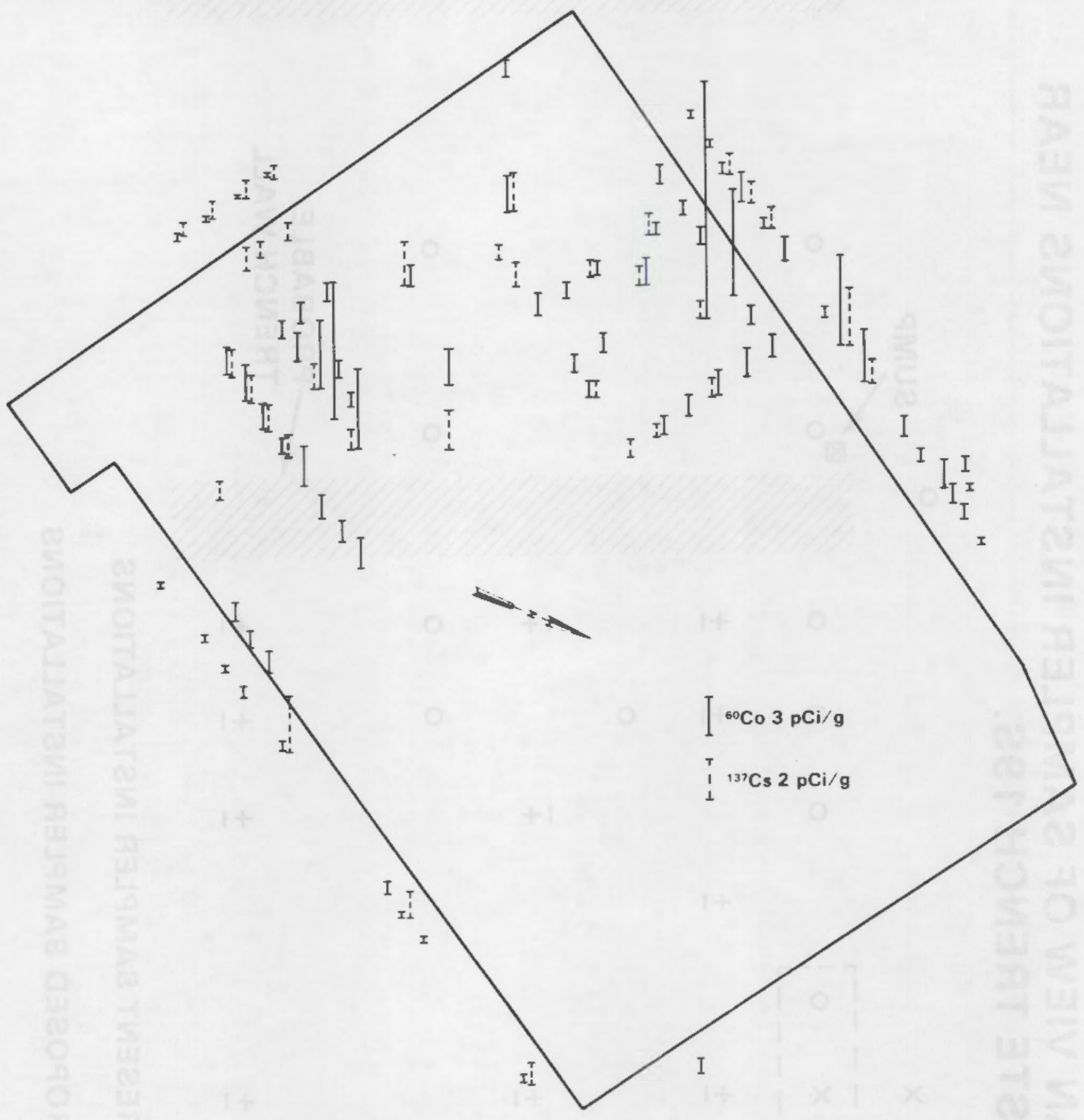

FIGURE 4 


\title{
SECTION II
}

\author{
SUMMARY OF \\ MAXEY FLATS RESEARCH PROGRAM
}

Dames \& Moore

White Plains, New York 10603 
SUMMARY OF

DAMES \& MOORE*

MAXEY FLATS RESEARCH PROGRAM

BY

JAMES CLANCY, ESTEBAN PICAZO,

GARY RE, AND MICHAEL ZISKIN ${ }^{*}$

\section{SUMMARY REPORT}

In the fall of 1978, Dames \& Moore embarked on a water and radiocontaminant mass balance study at the Maxey Flats Low-Level Radioactive Waste Disposal Site. Prior to 1978, considerable environmental and political debate had been carrled out with respect to the overall significance of the environmental releases from this low-level waste disposal facility (LLWF). Several postulations by varlous investigators as to the nature and magnitude of releases by way of atmosphere, surface, and subsurface pathways had been made. Based on previous investigations performed by Dames \& More for the Commonwealth of Kentucky, it was readily apparent that if successful remediation were to be accomplished at this site to minimize environmental releases, a reasonable level of knowledge as to the water and radiocontaminant balance was necessary.

In order to achieve a thorough water and radiocontaminant mass balance of the Maxey Flats LLWF, a four component research program was initiated. This four part program consisted of 1) a s1te mapping study, 2) a water and sediment study, 3) an airborne particulate study, and 4) an evaporator effluent and trench gas study. To accomplish these atudies, extensive fleld efforts have been required. The major focus of effort on radiocontaminant mass balance was on the radionuclides ${ }^{3} \mathrm{H},{ }^{60} \mathrm{Co},{ }^{90} \mathrm{Sr},{ }^{137} \mathrm{Cs},{ }^{238} \mathrm{Pu}$ and ${ }^{239} \mathrm{Pu}$.

*White Plains, New York 10603.

Project Geochemist, Assistant Health Physiclst, Project Health Physicist, and Assistant Environmental Sclentist respectively. 
The site mappling studies have included a restricted area topographic and facllity mapping effort, a gamma radiation mapping effort, and a soll contamination level effort. These efforts were stimulated by a serious lack of both a good topographic and planax map. It was hoped that preparation of topographic, planar, and radiation mapping would also ald in the better delineation of trench boundaries. The exact dimensions and boundarfes of burial trenches has not been well estab11shed. The preparation of the maps for this program have alded this trench boundary delineation. The maps (see Figures 1, 2 and 3) prepared from this effort have already proven valuable to other research efforts at the site (e.g., USGS and Brookhaven National Laboratory).

The radiation mapping has proven to be an effective screening procedure for locating areas of soll contamination. Radiation mapping of the restricted area at Maxey Flats was performed on a 10 meter grid using a portable sodium lodide (NaI) crystal survey meter during the fall of 1978. The 10 meter grid system was laid out by a licensed surveyor with wooden stakes. The corners of the imposed grid have been made into permanent bench marks to afford future reproductbility of this same grid. The soll sampling effort which was designed based on the gamma radiation survey data has resulted in the delineation of areas of relatively significant soll contamination. These areas of soll contamination include elevated concentrations of ${ }^{137} \mathrm{Cs}$ (up to $220 \mathrm{pCi} / \mathrm{g}$ ), ${ }^{60} \mathrm{Co}$ (up to $1680 \mathrm{pCl} / \mathrm{g}$ ), ${ }^{125} \mathrm{Sb}$ (up to $1280 \mathrm{pCi} / \mathrm{g}$ ), and ${ }^{238} \mathrm{Pu}$ (up to $1035 \mathrm{pC} 1 / \mathrm{g}$ ). These areas of soll contamination have probably contributed to offsite releases of radionuclides by way of soil erosion and atrborne resuspension. The radiation mapping effort was extended to the drainage areas lumedlately surrounding the restricted area. Some minor levels of soll contamination have been observed near the restricted area fenceline along the eastern and western slopes of the site.

The elements of the water and sediment mass balance study include: 1) an automatic time composite stream monitoring system, 2) flow 
measurement studies on the adjacent streams, 3) collection and analysis of both suspended sediments and bed sediments from both adjacent streams and site runoff channels, 4) Installation and operation of primary measuring devices along the major dratnage channels at the site, 5) collection and analysis of runoff water samples, and 6) meteoric water balance studies including rainfall, evaporation, and Infiltration data collection (See Figure 4).

The time composite stream samples have provided good average (time weighted) concentration data on radiocontaminant concentrations in the adfacent streams. For the most part, tritfum is the only radionuclide in significantly elevated concentrations observed in the four stream monftoring stations with concentrations typically rangling from 2,000 to $10,000 \mathrm{pCi} / 1$. At the closest stream station to the site, ${ }^{90} \mathrm{Sr}$ has been observed in detectable concentrations (about $2 \mathrm{pC1} / 1$ ) with reasonable consistency.

Suspended sediments have been collected by field filtration apparatus. The field apparatus is capable of collecting suitable sample weights of less than 0.8 micron samples for sensitivity on the order of 0.01 $\mathrm{pCi} / \mathrm{g}$ for the radionuclide suite for which the sample ia analysed. At this sensitivity level, detectable concentrations ranging up to several picocuries/gram have been observed. With respect to bed sediments, elevated concentrations of ${ }^{90} \mathrm{Sr}$ and ${ }^{137} \mathrm{Cs}$ have been observed to diminish with distance from the restricted area. For the most part, the bed sediments collected are falrly coarse-grained sediments and are not expected to contain the major fraction of sediment transported radiocontaminants.

A parshall flume and a v-notch weir have been installed in the south and main east washes, respectively, at the site. Flow is continuously monitored and later correlated with rainfall data. Based on the data collected so far at the site, 1t appears that the surface runoff component of the site ranges from 20 to 35 percent of the rainfall component depending on the degree of soll saturation at the site. 
Grab samples of runoff from numerous locations within the drainage channels at the site have been collected. The principal radioncontaminants observed in these samples have been trititum (300,000 to $500,000 \mathrm{pCl} / 1$ ) and ${ }^{90} \mathrm{Sr}(5$ to $40 \mathrm{pCl} / 1)$.

The site water balance has included rainfall measurement at two near site locations, four Class A evaporation pan experiments, a continuously operating evaporimeter, and four double-ring infiltrometer experiments. The evaporation pan experiments have shown evaporation rates rangling from zero to $2.8 \mathrm{~mm} / \mathrm{hr}$. The infiltration rate experiments have indicated rates ranging from zero to $1.7 \mathrm{~cm} / \mathrm{hr}$. Based on these preliminary results and trench water level data, 1t appears that about 2 to 3 percent of the annual rainfall infiltrates the trenches.

The afrborne particulates studies consisted of the positioning of elght afrborne particulate samplers around the periphery of the site. Two sampling periods of 5 to 8 week duration were used. A frequency of wind ocurrence analysis was performed using the wind speed and direction data collected by Nuclear Engineering Company (NECO) during 1976 and 1977.

During the 900 to 1300 hour sampling collection periods when alr was sampled at a rate of between 1.4 and $2.4 \mathrm{~m}^{3} / \mathrm{hr}$, samples ranging between 74 and $115 \mathrm{mg}$ were collected. The average observed particulate air concentration was on the order of 25 to $85 \mathrm{~g} / \mathrm{SCMD}$. The airborne particulates were observed to be slightly contaminated with ${ }^{90} \mathrm{Sr}$ and ${ }^{137} \mathrm{Cs}$ (concentrations ranging from 17.6 to $229 \mathrm{pCi} / \mathrm{g}$ and 7.8 and $53.4 \mathrm{pCi} / \mathrm{g}$, respectively). Detectable concentrations of ${ }^{60} \mathrm{Co}$ were only observed at three of the eight sampling stations. Plutonium was observed in detectable concentrations at only three of the eight stations. With the exception of ${ }^{90} \mathrm{Sr}$, the airborne particulate concentrations of radionuclides at Maxey Flats are not significantly higher than concentrations observed at DOE sampling stations throughout the United States. 
Two evaporator effluent and two trench gas sampling efforts were conducted at the site between December of 1978 and July of 1979. Isokinetic sampling of evaporator effluent has shown annual tritium emissions of greater than $20,000 \mathrm{cl}$. Based on these effluent study results, the annual ${ }^{137} \mathrm{Cs}$ emission has been calculated to be about $100 \mathrm{mCi}$. The annual emission rates for plutonium have been calculated to be at the microcurie level. Significant carryover of non-tritium radionuclides was observed during these sampling efforts.

The trench gas and radon emunation studies were carried out in December, 1978 and July 1979. The trench gas, sol1 gas, and ambient air concentration data indicate conditions which are consistent with the chemical and physical environment of the burial trench. Methane and carbon dioxide generation appears to be occurring in several trenches. This observation is consistent with the expected decomposition of organic material buried in the trenches. These gases have mobllized ${ }^{14} \mathrm{C}$ and tritium from the buried waste; however, the emission of these mobilized radionuclides through the trench covers appears to be negligible. Similarily, large concentrations of ${ }^{226} \mathrm{Ra}$ have been buried. However, the emanation of ${ }^{222} \mathrm{Rn}$ (daughter of ${ }^{226} \mathrm{Ra}$ ) through these relatively thick low permeability covers appears to be negligible. Some gaseous emanation of these radionuclides can be expected from uncapped sump pipes. Yet, in general, the contribution of trench and soil gas radionuclides to the site environs appears to be minimal. 


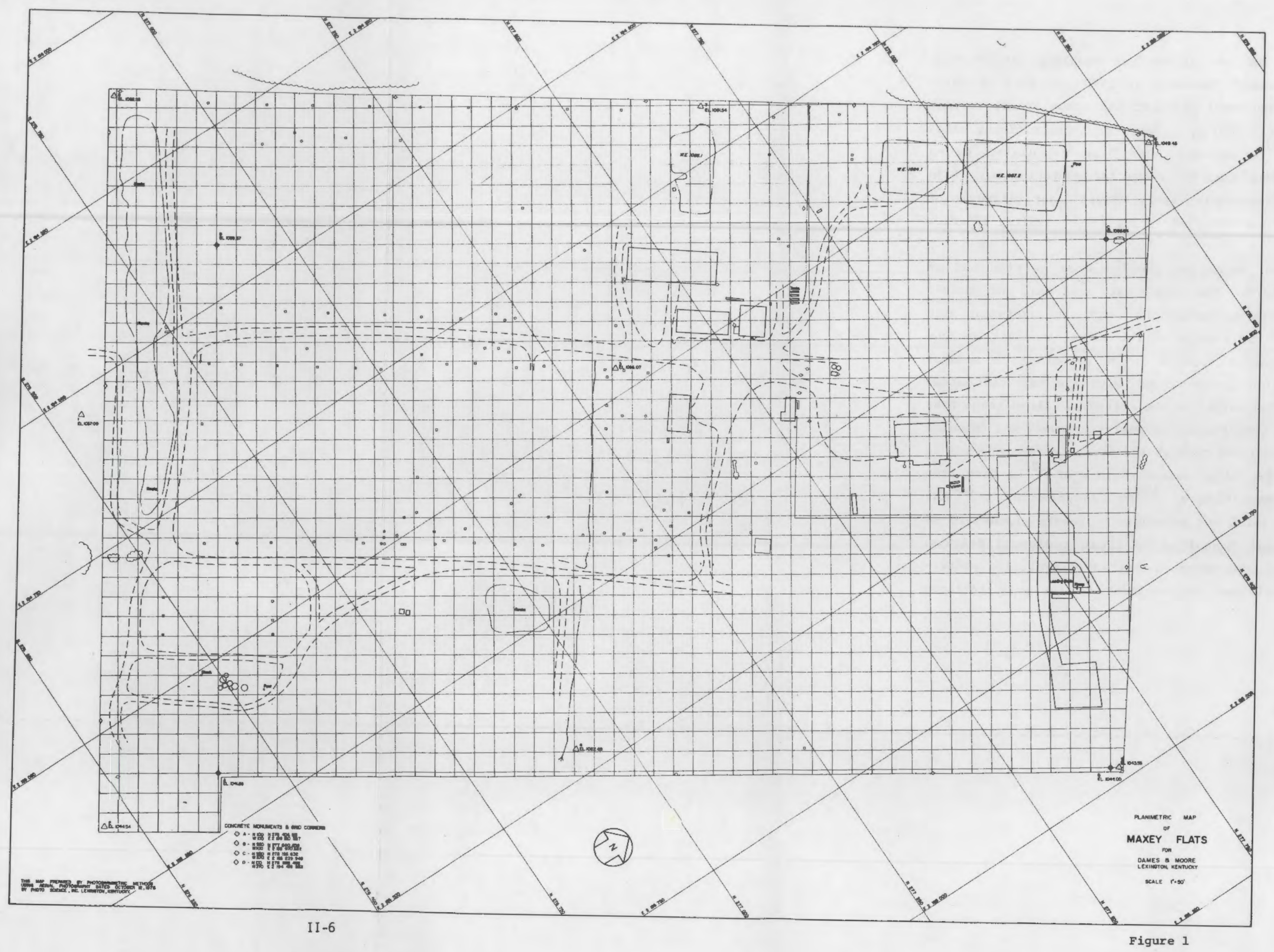




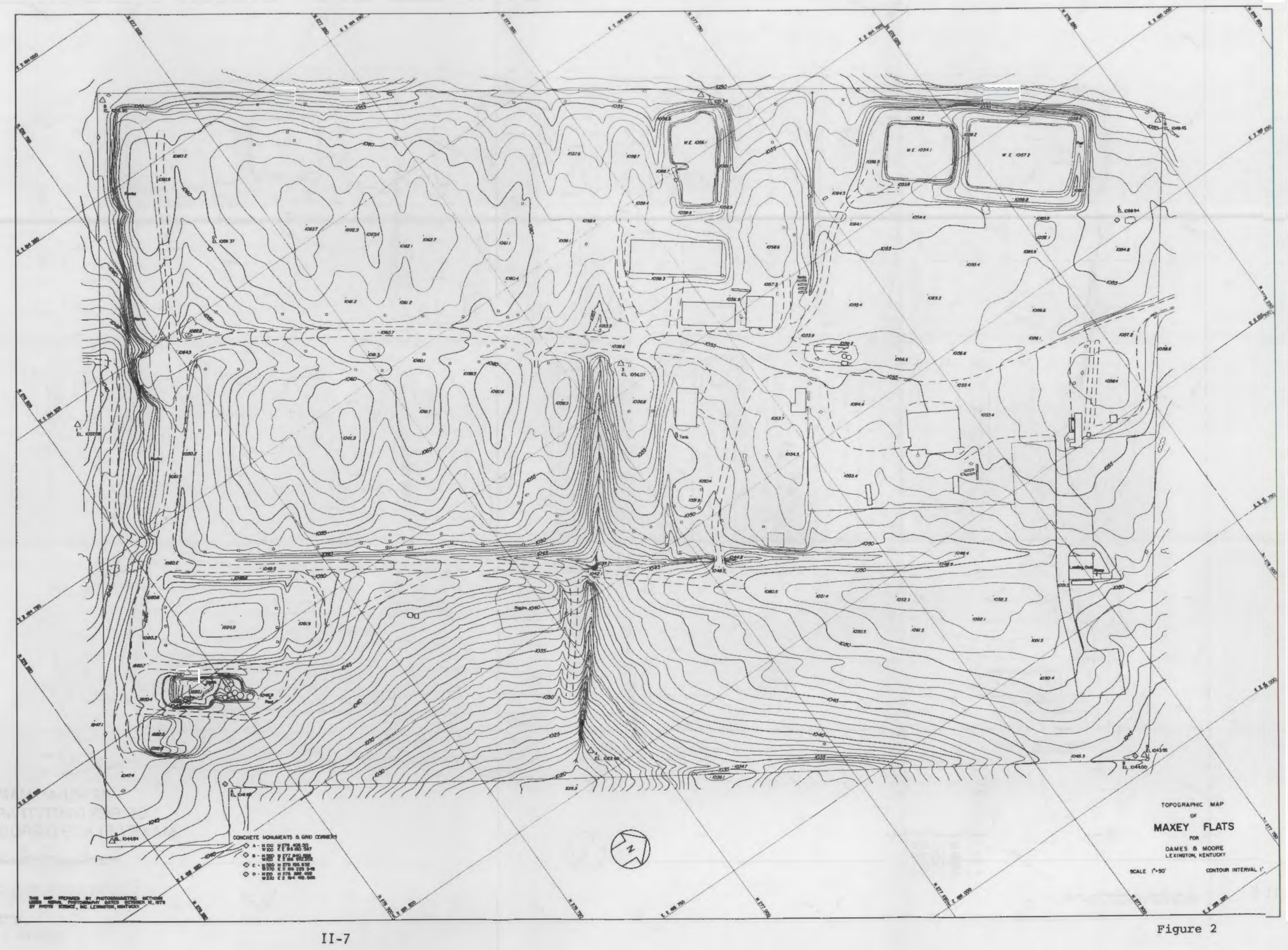




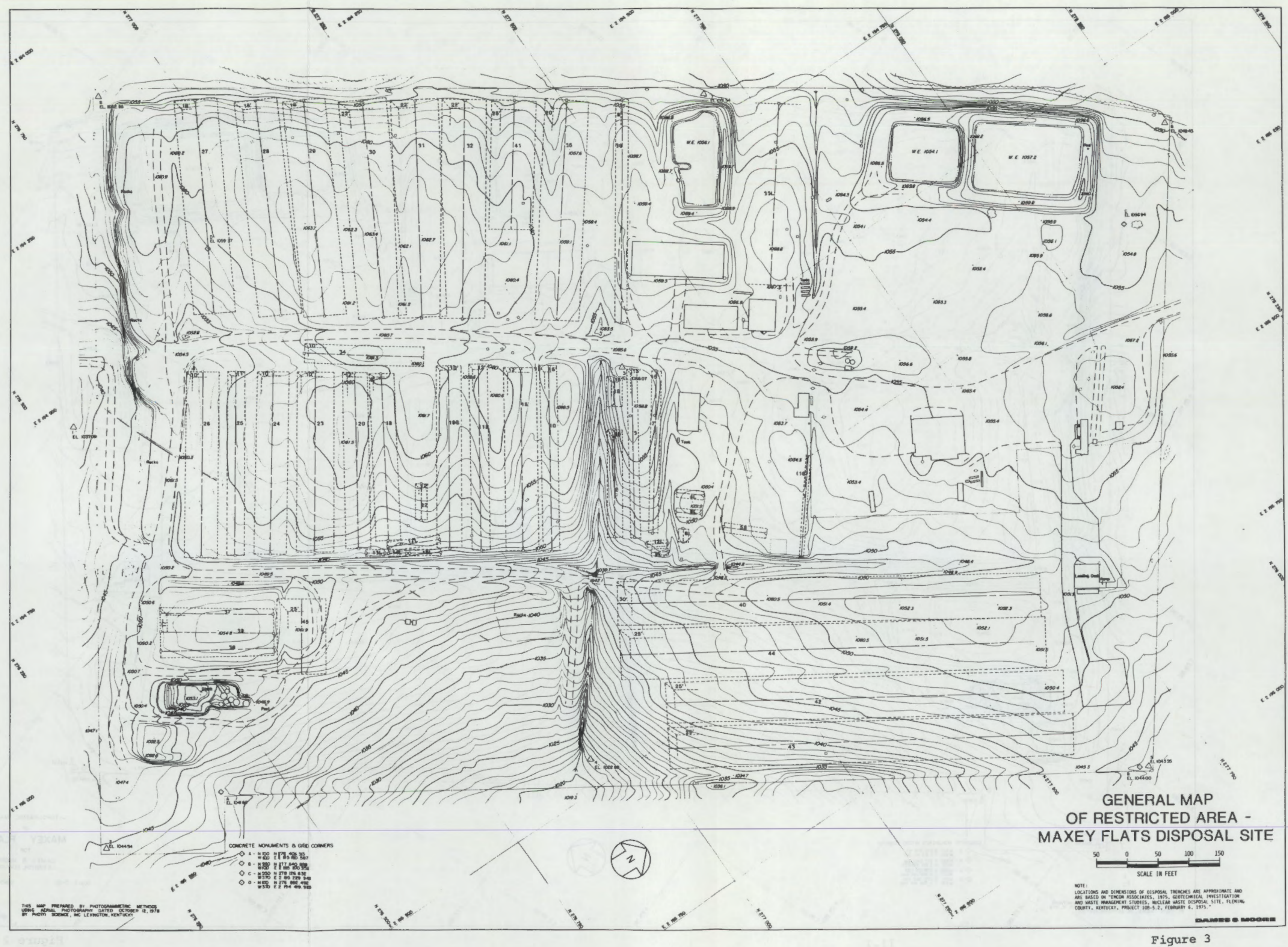




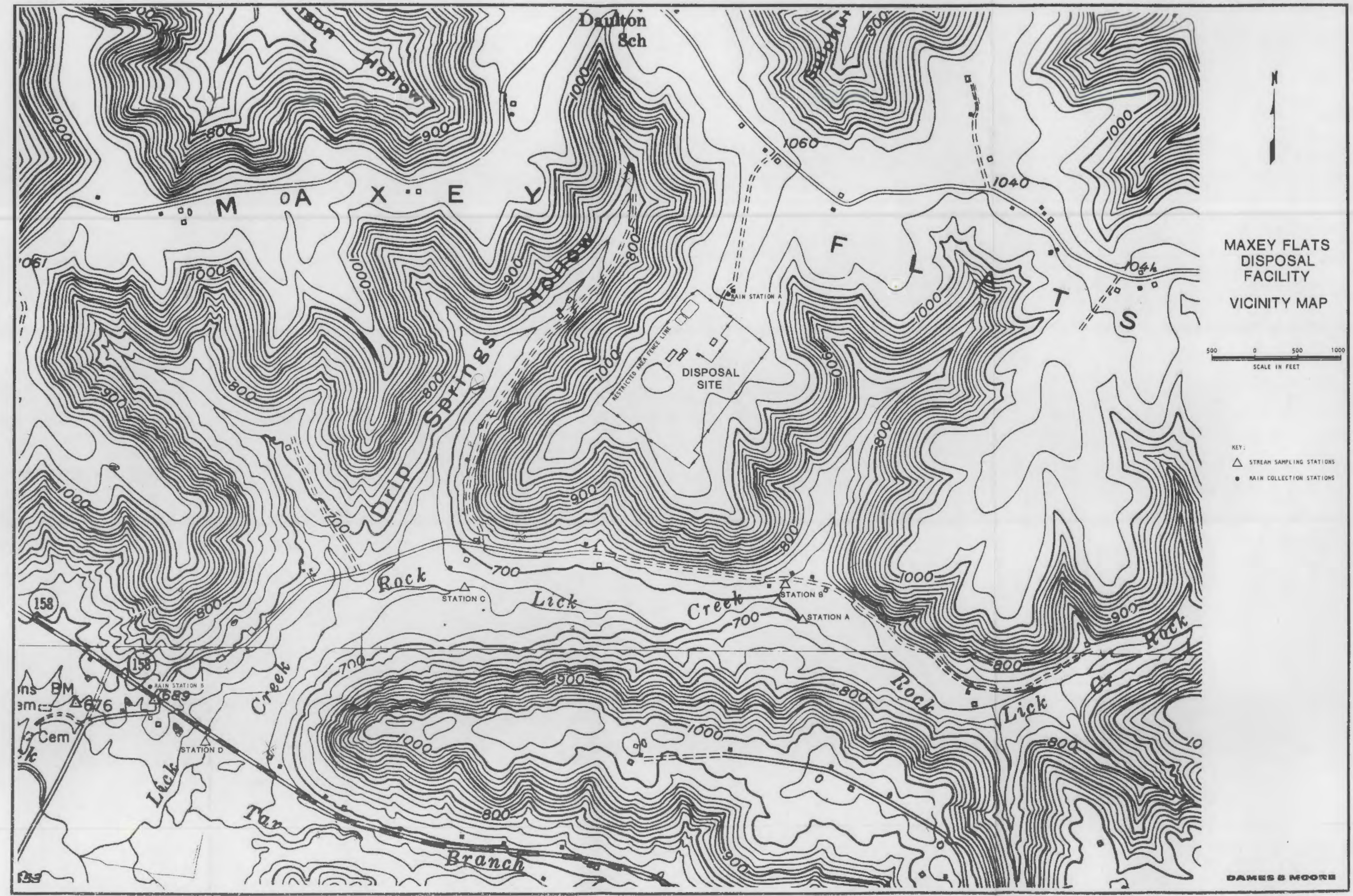



SECTION III

\section{TRENCH WATER-SOIL CHEMISTRY AND INTERACTIONS \\ AT THE MAXEY FLATS SITE}

Brookhaven National Laboratory

Department of Nuclear Energy

Upton, New York 11973 
TRENCH WATER-SOIL CHEMISTRY AND INTERACTIONS AT THE MAXEY FLATS SITE

\author{
Al len J. Weiss and Kenneth S. Czyscinski \\ Brookhaven National Laboratory \\ Department of Nuclear Energy \\ Upton, N.Y. 11973
}

August 1980

Summary:

This report contains information extracted from a larger program designed to provide an understanding, and to monitor the behavior, of existing Iow-level disposal sites. This broad investigation will provide source term data for radionuclides and other solutes in disposal trench waters, and will describe the physical, chemical, and biological properties of the geochemical system that controls radionuclide movement. General conclusions can be made from the data in terms of source term information to be used in modeling efforts, as well as processes which may affect radionuclide migration.

Disposal trench waters at Maxey Flats are complex anoxic chemical systems which require more extensive investigation to quantitatively assess their role in radionuclide retention and mobilization. No overall systematic changes in the disposal trenches were observed during the brief sampling interval (4 years). However, changes in some radionuclide and cation concentrations were observed in several trenches. Numerous organic compounds were identified in trench waters at Maxey Flats, some of which have the potential for chelation with radionuclides.

The presence of radionuclides and organic compounds in wells UB1 and UB1-A and in nearby trenches indicates communication between the wells and trench water leachates by subsurface migration. Radionuclides were also measured in the new experimental trench dug parallel to trench 27 .

Aerobic, anaerobic, sulfate reducing, denitrifying, and methanogenic bacteria are present in the Teachate samples, and are able to grow anaerobically in trench leachates.

Experimental results indicate that the observed sorption $k_{d}$ is a function of both solid and liquid phase compositional variations, as well 
as contact time. Lowest $K_{d}$ results are observed with anoxic trench waters and ultrasonicated soils. This observation indicates the need to use site specific materials and experimental conditions which simulate in situ conditions as closely as possible in laboratory sorption experiments.

\section{Introduction:}

This report concerning the Maxey Flats, Kentucky, site is part of an overal 1 program designed to provide experimental research support to the U.S. Nuclear Regulatory Comnission in the development of criteria for the selection and licensing of solid low-level radioactive waste disposal sites. One of the significant factors in the development of these criteria is the ability to make predictions on the rate of radionuclide movement along the groundwater flow path. This study attempts to provide an understanding, and to monitor the behavior, of existing low-level disposal sites.

In cooperation with the U.S. Geological Survey, a field and laboratory program was initiated to study the existing commercial low-level radioactive waste disposal sites. This investigation will define the source terns (concentrations in solutions) for radionuclides and other solutes in trench waters at the sites, and will describe the physical, chemical, and biological properties of the geochemical system that control the movement of radionuclides.

Three major areas of study are included in this program: (i) trench water analysis, (ii) microbiological processes, and (iii) geochemical considerations.

\section{Trench Water Analysis}

Procedures for the collection, preparation and analysis of trench waters were developed when necessary, to supplement standard procedures. Inorganic, organic, and radiochemical constituents in trench waters are being measured and their relevance to movement of radionuclides is being evaluated. Water from test wells in and around the disposal sites is being sampled to detect and characterize radionuclides along the groundwater flow paths. 


\section{Microbiological Processes}

Microbial degradation of organic material buried in the trenches may contribute directly or indirectiy to the migration of radionuclides. The consequences of the interaction of radionuclides present in the trenches with the products of microbial activity are being measured and evaluated, e.g., gas generation and formation of soluble organoradionuclide complexes.

\section{Geochemical Considerations}

The geochemical aspects of radionuclide migration and retention treated in this portion of the program are limited to laboratory sorption studies, involving batch and column experiments using sitespecific materials and performed under conditions which simulate the field situation. Data and ideas developed from these studies will be compared to the results of core analysis for field verification. Conclusions derived from these studies are expected to have direct application to modeling studies of some of the sites and to the establishing of siting criteria and improved burial practices at future sites.

\section{Experimenta1 Approach:}

The objective of the analytical program is to measure the concentrations of radionuclides and other chemical species present in trench waters. Procedures were designed to maintain the anoxic nature of the trench waters during collection, storage, and subsequent handling. A schematic diagram of the water collection system is shown in Figure 1. 0xygen leaking into the samples will result in the formation of an iron (ferric) hydroxide precipitate. After collection, the water samples are stored in 4-liter borosilicate glass bottles designed to maintain the trench water environment. The anaerobic collection procedure al lows samples to be stored for months without visible signs of the reddish-brown ferric hydroxide that forms after exposure to air.

Selected physico-chemical characteristics of trench waters, which are subject to change during storage, are measured at the time of sample 


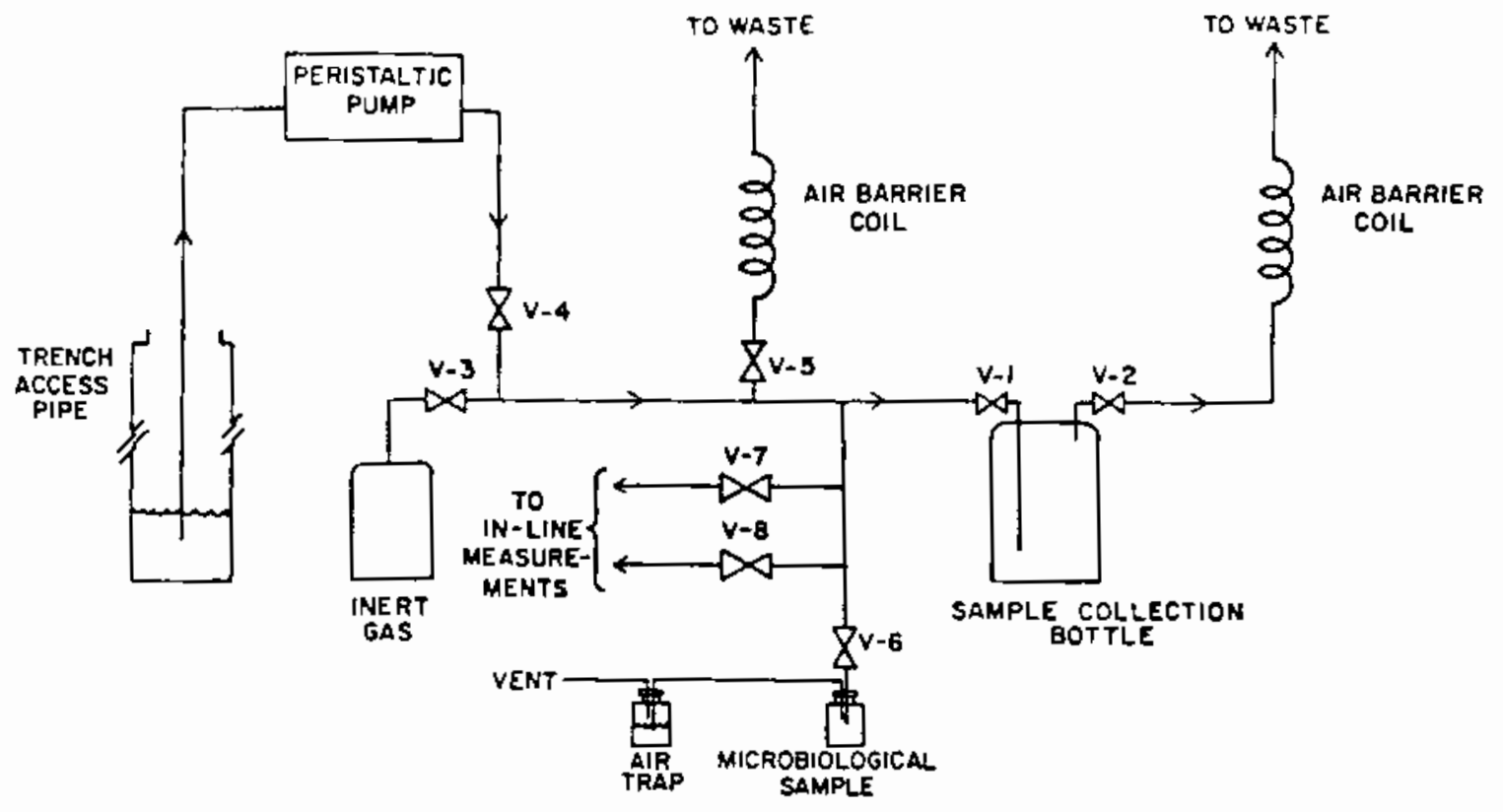

Figure 1. Schematic diagram of the system for anoxic collection of water.

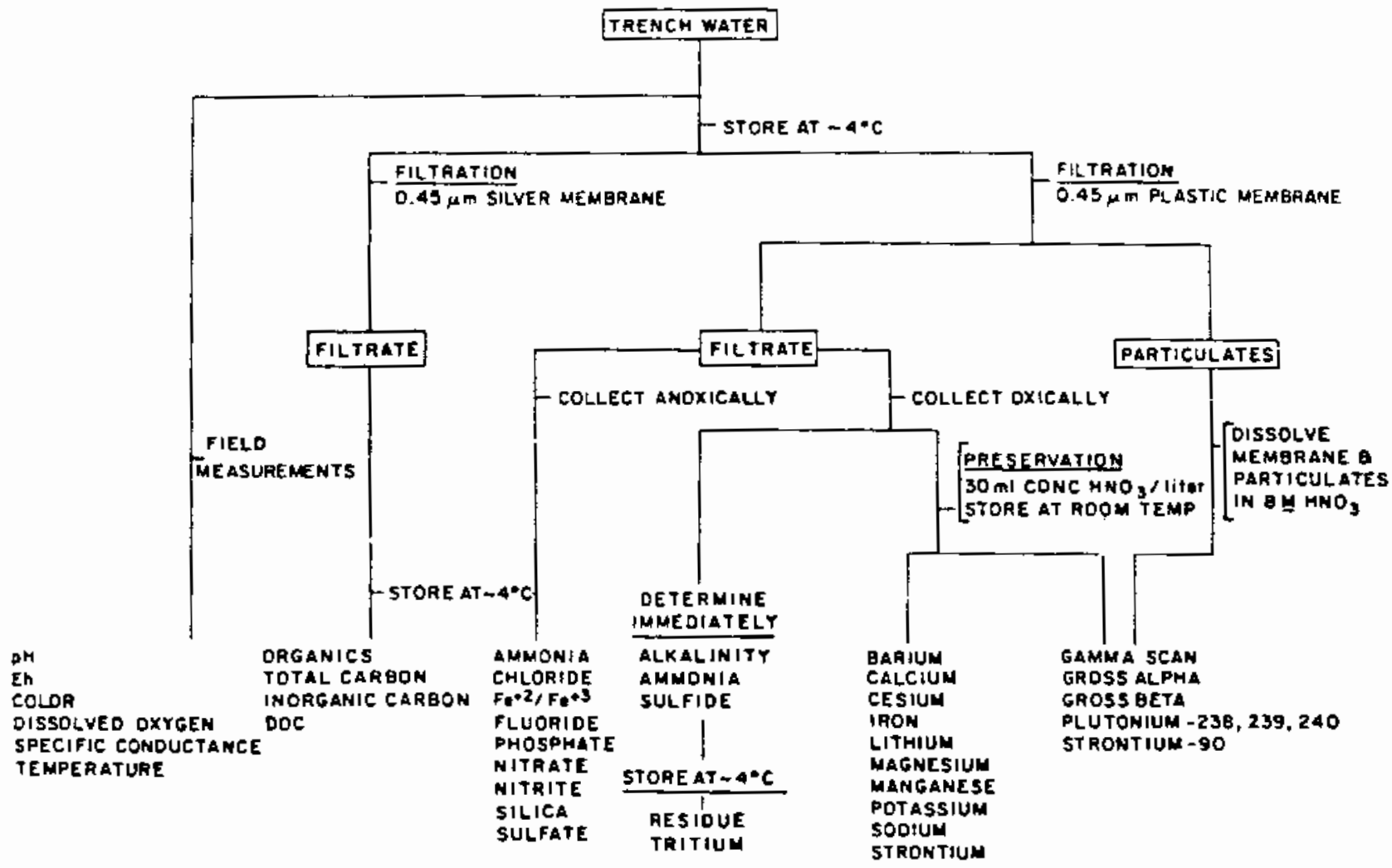

Figure 2. Scheme for partitioning water samples for analysis. 
collection. Temperature, pH, redox potential (Eh), dissolved oxygen, and specific conductance of the trench water samples are measured in-line during collection.

Upon arrival at BNL, the trench water samples are filtered through 0.45 kn membrane filters to remove any particulate matter present. Filtering is also done under an inert atmosphere to maintain the anoxic character of the waters. The filtrate is divided into several fractions and processed according to the scheme shown in Figure 2.

Trench waters are analyzed for major inorganic constituents using ion specific electrodes, colorimetric, and atomic absorption methods. Organic compounds are determined by solvent extraction followed by gas chromatographic and mass spectrometric analyses. Radiochemical analyses are performed by gas flow proportional counting (alphas and betas), liquid scintillation counting (tritium), Ge(Li) gamma-ray spectroscopy, and radiochemical separations (strontium-90 and plutonium isotopes). The particulate fraction is analyzed for radiochemical constituents only.

Site specific batch $K_{d}$ studies are performed with Maxey Flats soil and trench waters under inert atmosphere to simulate the anoxic conditions in the trenches. The initial $k_{d}$ experiments were intended as scoping studies to determine the $K_{d}$ dependency as a function of (i) $\mathrm{pH}$, (ii) soil/water ratio, (iii) water composition, (iv) oxic vs anoxic water regimes, (v) soil composition (ground/sieved vs untreated soils), and (vi) time, rather than definitive studies of the geomedia sorption properties at any particular disposal site.

The general method of preparing samples for $k_{d}$ measurements involves adding radionuclide spikes to filtered trench water, and perfoming a series of operations in a manifold or in a glove box ( $\mathrm{pH}-\mathrm{Eh}$ measurements, dilution, and addition of soil) to maintain the anoxic character of the system. To equilibrate the soil and water, the samples are tumbled in an apparatus designed to maintain the anoxic environment. A mixture of isotopes was used containing fission products ( $\mathrm{Cs}$ and $\mathrm{S} r$ ), an activation product $(\mathrm{Co})$, a transuranic $(\mathrm{Am})$, and europium to simulate plutonium behavior. The 
activity remaining in the liquid phase is determined by gamma-ray spectroscopy.

Details of the procedures described above are reported elsewhere. (1)

Results and Discussion:

Trench Water Analyses

Results of the analyses of several trench and well water samples collected from the Maxey Flats disposal site between September 1976 and May 1978 are shown in Tables 1-3. The location of trenches and wells are shown in Figure 1 of the executive summary. Additional data from Maxey Flats and results of similar measurements from the West Valley, New York; Sheffield, Illinois; and Barnwell, South Carolina, disposal sites are reported elsewhere. (1)

Trench waters are complex water systems as illustrated by the shapes of acid-base titration curves in Figure 3. The curve obtained with water fram well UB1-A resembles a typical simple groundwater.

No overall systematic changes in the disposal site trenches were observed during the brief sampling interval, which is short relative to the functional lifetime of the site. However, changes in some radionuclide and cation concentrations were observed in several trenches. Tritium was the most abundant of the radionuclides and was found in all trench waters. Chemically bound as HTO, tritium would be the most mobile radionuclide. Strontium-90, $238,239,240 \mathrm{Pu}$ and ${ }^{137} \mathrm{Cs}$ were found as dissoived species in all trench waters and sorbed on suspended particulates.

Results of the GC/MS analyses of water from trench 19S, trench 32, and well UB1 are shown in Table 2. The organic compounds found in the trench waters consisted of straight-and branched-chain aliphatic acids, aromatic acids, alcohols, aldehydes, ketones, amines, aromatic hydrocarbons, esters, ethers, and phenols. The types of compounds identified reflect both the nature of the buried waste and the products of biodegradation.

A comparison of organics identified in well UBl and trench 32 shows that every compound in well UBl, except toluic acid, is present in trench 
Table 1

Concentration of Missoived Radionuclides in Hater Samples Taken From Maxey Flats. Kentucky, Disposal Site

$\Gamma \mathrm{C} 1 / \mathrm{L}( \pm 2 \pi \mathrm{x})^{\mathrm{a}}$

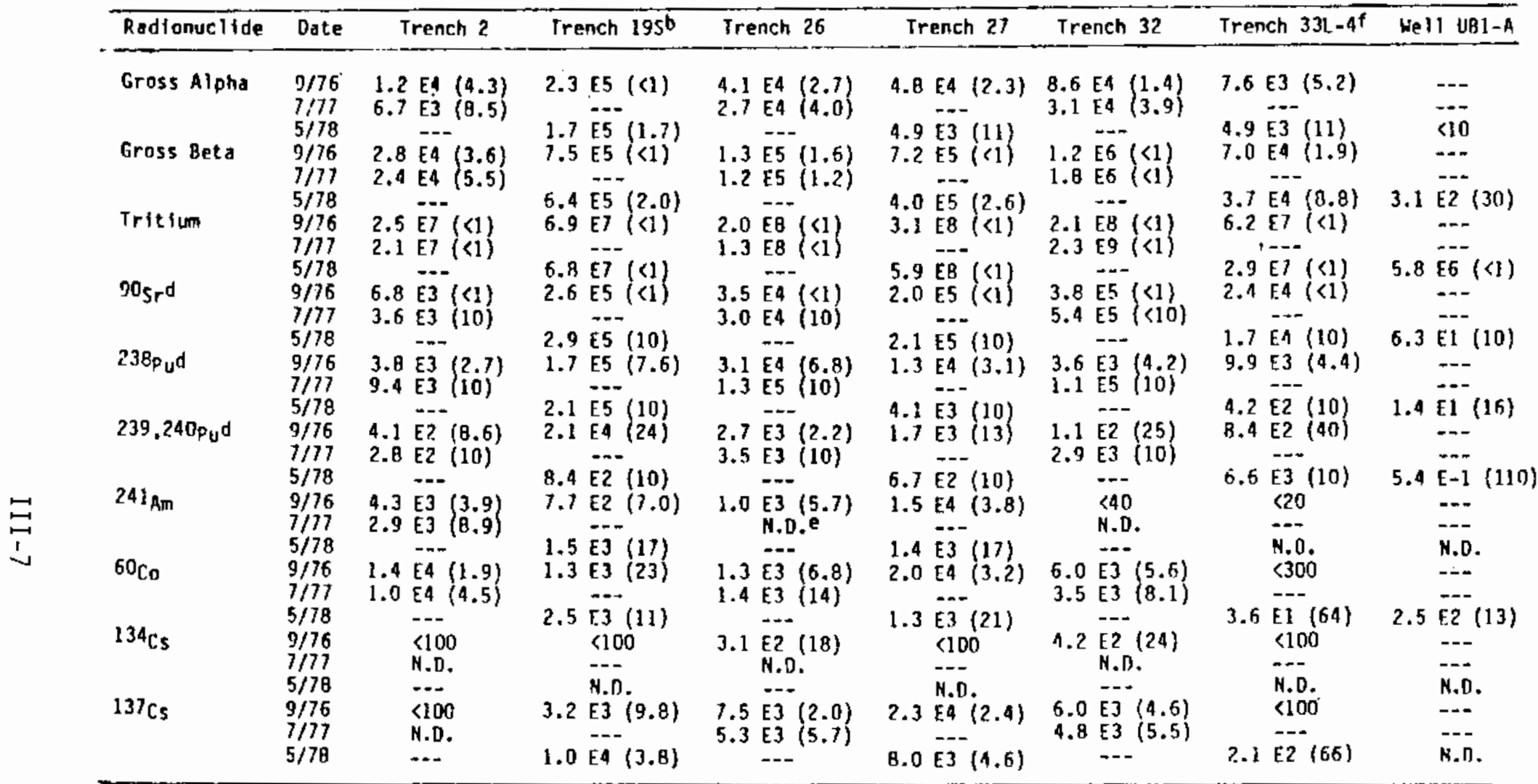

a Number in ( ) $=20$ percent count ing uncertainty.

bTrench 195 sample collected $9 / 76$ contained $2.3 \mathrm{EL}$ (11) $\mathrm{pCi} / \mathrm{L}{ }^{22} \mathrm{Na}$ in addition to radionuclide 1 isted in table.

di.. indicates sample was not collected from trench on indicated date.

Analyses of $7 / 77$ and $5 / 78$ series perfomed by LFE Laboratories, Richmond, Californta.

ef.0. * not detected.

french 33L-4 sample collected $5 / 78$ contained $8.8 \mathrm{EO}$ (22) $\mathrm{pCi} / \mathrm{L} 22 \mathrm{Na}$. 
Table 2

Organic Compounds Identified in Water Samples From Maxey Flats, Kentucky, Disposal Site $(\mathrm{mg} / \mathrm{l})$

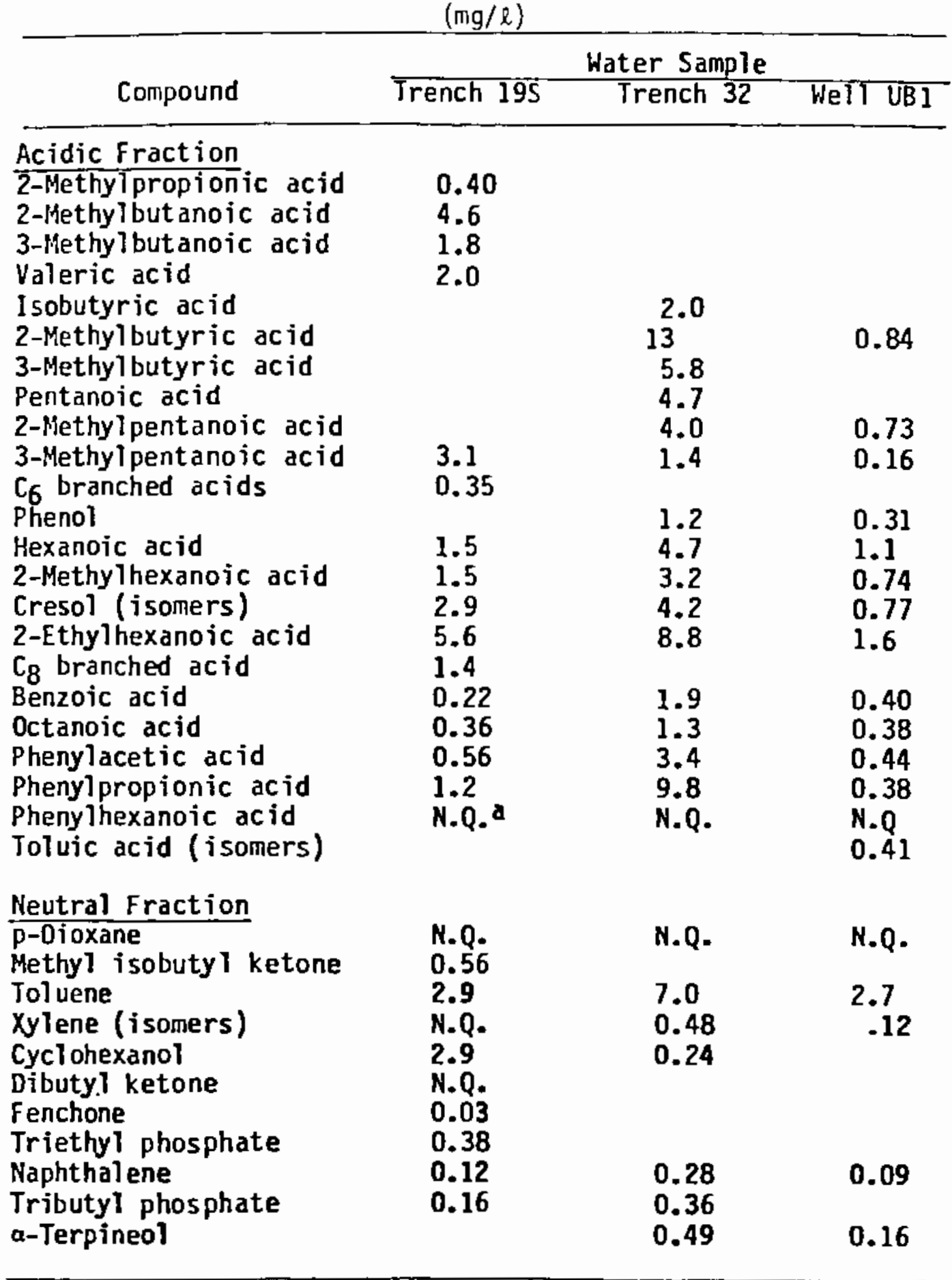

aNot quantified. 
Table 3

Analysis of Trench and Hell Hater Samples Taken From Haxey Flats. Kentucky $(10 / 30-11 / 2 / 79)$ $(m g / l)^{\mathrm{a}}$

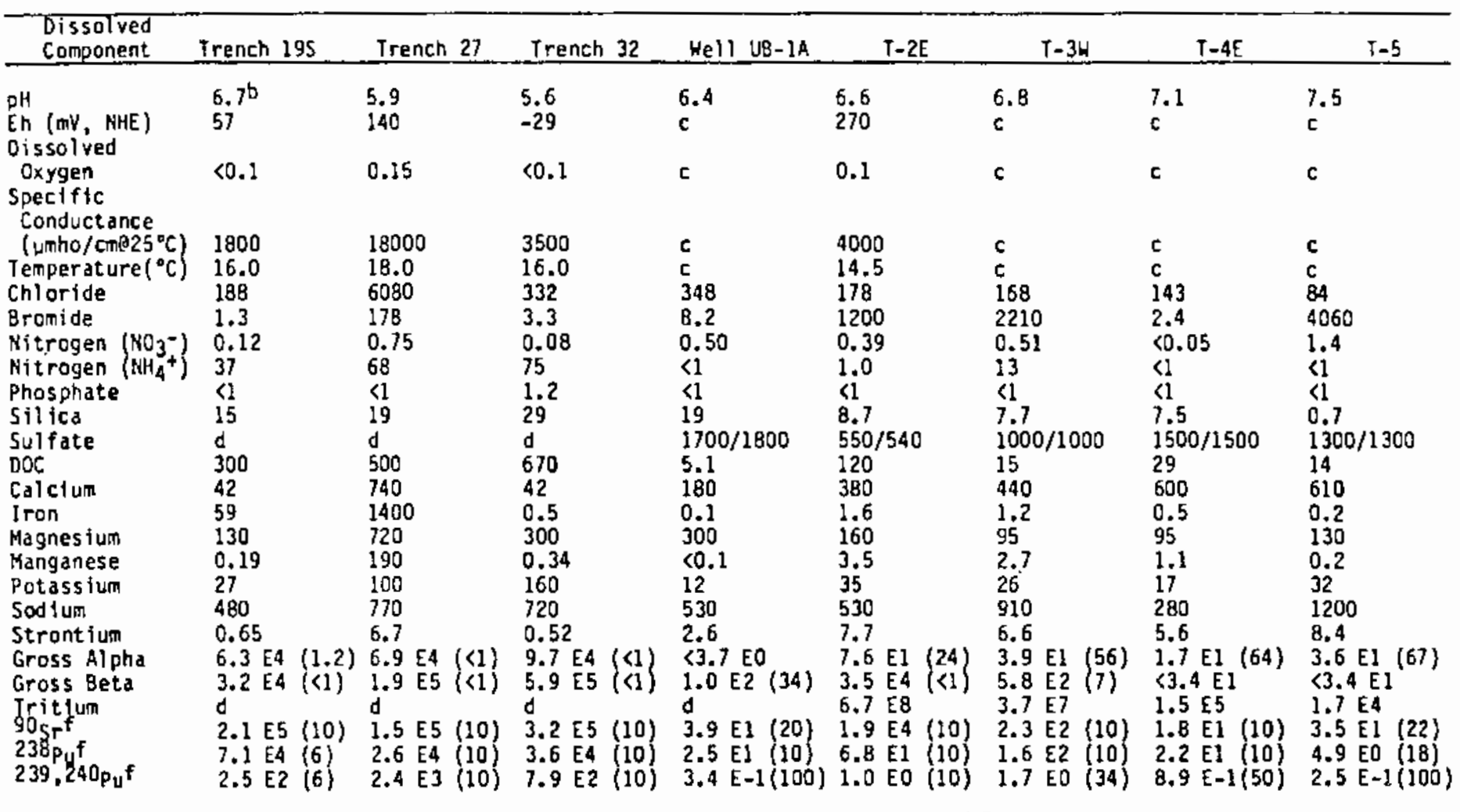

areasurement given in $\mathrm{mg} / \mathrm{l}$, unless otherwise noted.

bLaboratory measurement.

CIn-line measurement not made.

dAnalyses not completed.

eotermined by: colorimetric procedure/lon-chromatography.

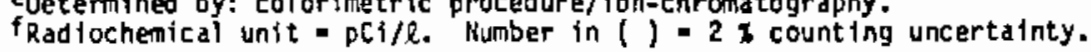




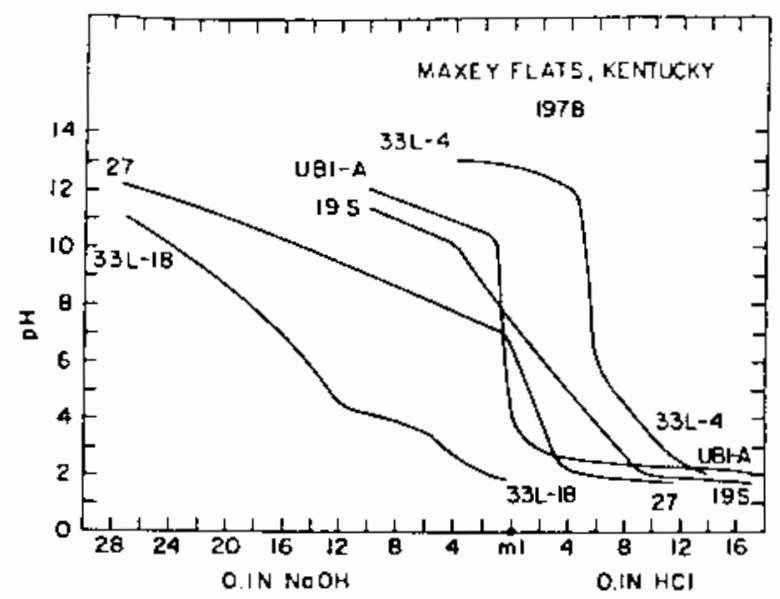

Figure 3. Acid-base titration curves of water samples from Maxey Flats, Kentucky, disposa? site, May 1978.

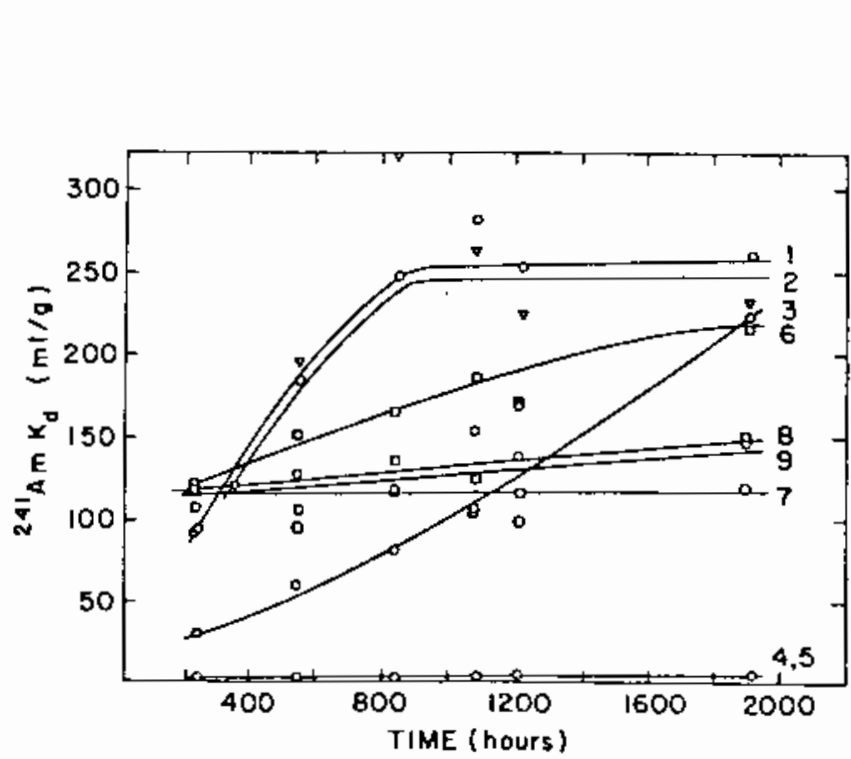

Figure 4. $241_{\text {An }} K_{d}$ sorption coefficient versus time for waters and soils from Maxey Flats, Kentucky, Disposal Site.

Wa ter:

Oxic

Soil: $\quad$ Ultrasonicated

Solution/soil ratio: $20 \mathrm{ml} / \mathrm{g}$

Reaction Container: TFE Tefion

\begin{tabular}{cccc}
\multicolumn{5}{c}{ MF } & & \\
Experiment & Code & Water & Soj] \\
\hline 1 & 155 & 19S & shale \\
2 & 155 & $19 S$ & sands tone \\
3 & 156 & We 11 UB1A & shale \\
4 & 157 & 27 & shale \\
5 & 157 & 27 & sandstone \\
6 & 158 & $33 L-4$ & shale \\
7 & 158 & $33 L-4$ & sandstone \\
8 & 159 & $33 L-18$ & shale \\
9 & 159 & $33 L-18$ & sandstone
\end{tabular}


32, and a majority of these compounds are present in trench 19S. Other nearby trenches which were not sampled may also contain these compounds. The presence of radionuclides and organic compounds in wells UBI and UBImA, and atso in nearby trenches, indicates communication between the wells and trench water leachates, and that migration of radionuclides from trenches has occurred.

To determine the movement of radionuclides by subterranean routes on the site, a new experimental trench was dug parallel to trench 27 to intercept water flowing from the burial trench area. Partial analyses of water collected (10/30-11/2/79 - a few weeks after completion of the trench) from four of the five sections are shown in Table 3. Also shown are the analyses of water taken during the same sampling period from the burial trenches and an observation well. Only trench section T-2E had sufficient water to obtain in-line measurements. Alpha, beta, tritium, strontium-90, and plutonium-238,239,240 radioactivities were measured in the four trench sections. Section T-2E appears to have the most radioactivity, and also contains $120 \mathrm{mg} / 2$ of DOC, which is more than an order of magnitude greater than the DOC measured in well UBI-A. GC/MS analyses of the organics in $T-2 E$ show the presence of a few components including phenol, dioxane, C-8 acids, and 2-ethylhexanol.

\section{Microbiological Processes}

The microbiological study found that: (i) aerobic and anaerobic bacteria, sulfate reducing, denitrifying, and methanogenic bacteria are present in the leachate samples, ( $i$ i) the bacteria identified are Bacillus sp., Pseudomonas sp., Citrobacter sp., and Clostridium sp., (iii) mixed bacterial cultures isolated from the trench leachates are able to grow anaerobically in trench leachates, which indicates that the radionuclides and organics present in leachates are not toxic to these bacteria, (iv) the organic compounds in the leachates are utilized by the bacteria as a carbon source for growth, (v) preliminary studies on the anderobic degradation of organic compounds of the leachate sample indicate that several of the organic compounds are being both synthesized and destroyed by these bacteria, 
and (vi) methane bacteria present in the leachate samples produced appreciable amounts of tritiated and carbon-14 methane from the leachates.

\section{Sorption Studies $-K_{d}$}

Laboratory sorption studies have focussed on trench water geomedia systems from the Maxey Flats, Kentucky, and West Valley, New York disposal sites. Both sites are characterized by complex chemically reducing, anoxic trench waters and imperneable geomedia.

Sorption studies indicate that $k_{d}$ varies as a function of the experimental conditions. Variations of the experiment parameters discussed in the experimental section all affected the measured $K_{d}$ values. As an example, sorption $K_{d}$ curves for $241_{A m}$, shown in Figure 4 , 111 ustrate the $K_{d}$ dependence on time and experimental conditions, e.g., \#4 and \#5 reached a steady state early, \#3 was still increasing after 1900 hours, and \#1 and \#2 exhibited a rise until 800 hours. The variability of $k_{d}$ measured with different waters from the site under the same experimental conditions is illustrated by waters from trench 195, trench 27, and we11 UB 1-A (\#1 vs \#4 vs \#3). Similar sorption data for other radionuclides are reported el sewhere. (1)

A series of $K_{d}$ determinations were made using combinations of anoxic (trench waters) or oxic (trench waters after air exposure and filtration of precipitated iron hydroxides) water with both ground and seived (100 mesh fraction) or ultrasonically disaggregated samples of the geomedia. These experiments were performed with both the Maxey Flats, and West Valley, materials.

Results for these experiments show that, in general, the lowest $k_{d}$ is observed with ultrasonically disaggregated soil and anoxic trench water, the combination which most closely represents the imediate trench environment. Only the results for the Maxey Flats systems are shown in Table 4. These results emphasize the necessity for conducting $k_{d}$ experiments under site specific conditions. To obtain the most realistic $K_{d}$ estimates, actual conditions must be simulated as closely as possible.

The relative retention of the Maxey Flats geomedia for $C s, E u(P u)$ and $C o$, as reflected in the $x_{d}$ numbers reported here, are in general 
Table 4

Sorption Coefficients for Trench Water and Shale From

Maxey Flats, Kentucky, Disposal Site

(Soil and Water Pretreatment)

\begin{tabular}{|c|c|c|c|}
\hline & \multicolumn{3}{|c|}{$K_{d}(m l / g)^{a}$} \\
\hline & \multicolumn{3}{|c|}{ Soil Condition } \\
\hline & oxic & \multicolumn{2}{|c|}{ Anoxic } \\
\hline & \multicolumn{3}{|c|}{ Soil Condition } \\
\hline Radionuclide & $\begin{array}{cc} & \text { Ground } \\
\text { Ultrasonic } & 100-200 \text { Mesh } \\
\text { Disaggregation } & \text { Fraction }\end{array}$ & $\begin{array}{c}\text { Ultrasonic } \\
\text { Disaggregation }\end{array}$ & $\begin{array}{l}\text { Ground } \\
100-200 \text { Mesh } \\
\text { Fraction }\end{array}$ \\
\hline $\begin{array}{r}152_{\mathrm{Eu}} \\
24 \mathrm{l}_{\mathrm{Am}} \\
85_{\mathrm{Sr}} \\
134 \mathrm{Cs} \\
137_{\mathrm{Cs}} \\
60_{\mathrm{Co}}\end{array}$ & $\begin{array}{c}450 \pm 30 \\
1240 \pm 180 \\
6.1 \pm 0.8 \\
1430 \pm 80 \\
1210 \pm 60 \\
9 \pm 2\end{array}$ & $\begin{array}{c}420 \pm 20 \\
480 \pm 70 \\
4 \pm 1 \\
570 \pm 30 \\
550 \pm 30 \\
5 \pm 1\end{array}$ & $\begin{array}{c}1480 \pm 270 \\
900 \pm 20 \\
10.0 \pm 0.3 \\
490 \pm 2.0 \\
490 \pm 10 \\
11 \pm 2\end{array}$ \\
\hline $\begin{array}{l}\text { Trench Water: } \\
\text { Shale: } \\
\text { Solution/Soil Ratio: } \\
\text { Reaction Containers: } \\
\text { Equilibration Time: } \\
\text { Anoxic: } \\
\text { Oxic: } \\
\text { akdis reported as a } \\
\text { results. }\end{array}$ & \multicolumn{3}{|c|}{$\begin{array}{l}\text { Maxey Flats, disposal site, Trench } 27 \\
\text { (MF-157), collected anoxically May } 1978 \\
\text { Maxey Flats, disposal site, Trench } 46 \\
\text { (MF-III), unweathered shale at } ~ 7 \text { meters } \\
20 \mathrm{mx} / \mathrm{g} \\
\text { : } \\
\text { Figure F.7 (Weiss, et al., } 1980 \text { ) } \\
100 \text { hours } \\
\text { Original materials maintained in an argon atmosphere } \\
\text { Trench water was exposed to air to precipitate ferric } \\
\text { hydroxide. Samples were prepared from the solution } \\
\text { after the precipitate was removed by filtration. } \\
\text { an average } \pm \text { one standard deviation of the observed }\end{array}$} \\
\hline
\end{tabular}


agreement with field results presented by Polzer, Essington, and Fowler (this report).

Relatively low sorption capacity under anoxic conditions would indicate that these geochemical environments should be avoided for future disposal sites. However, other processes operative in these geochemical systems contribute to the total retention capacity rather than the sorption mechanism alone. Coprecipitation of radionuclides during sulfide or carbonate precipitation of iron, or other metals, is an excellent in situ scavenging mechanism. These trench waters also contain high dissolved ferrous iron concentrations which will oxidize and precipitate as hydroxides during groundwater migration away from the trench vicinity. Here again, coprecipitation of radionuclides during iron hydroxide precipitation is a well known purification technique. These mechanisms have not been quantified in the geochemically reducing trench environments at Maxey Flats, and West valley, but are expected to be important contributors to the total retention capacity.

Future sorption work will involve some batch experiments, and will also involve flow-through column experiments, which more closely simulate the field situation. Batch experiments will be designed to allow comparison with column experiment results, and provide infomation of a mechanistic nature which will be useful in predictive applications.

\section{References:}

A. J. Weiss, P. Colombo, J. H. CTinton, K. S. Czyscinski, S. Dobbs, R. F. Doering, A. J. Francis, G. G. Galdi, S. L. Garber, C. L. Green, C. R. Iden, B. J. Nine, R. F. Pietrzak, and J. Steiners, Brookhaven National Laboratory, "Evaluation of Isotope Migration-Land Burial, Water Chemistry at Conmercially Operated Low Level Radioactive Waste Disposal Sites," NUREG/CR-1289, BNL-NUREG-51143, 1980. Available for purchase from the NRC/GPO Sales Program, U.S. Nuclear Regulatory Commission, Washington, $D C$ 20555, and the National Technical Information Service, Springfield, VA 22161. 
SECTION IV

CHEMICAL SPECIES OF MIGRATING RADIONUCLIDES AT

MAXEY FLATS AND OTHER SHALLOW LAND BURIAL SITES

Pacific Northwest Laboratory

Richland, Washington 99352 
CHEMICAL SPECIES OF MIGRATING RADIONUCLIDES AT

MAXEY FLATS AND OTHER SHALLOW LAND BURIAL SITES

L. J. Kirby

Pacific Northwest Laboratory

Richland, Washington 99352

\section{INTRODUCTION}

One of the most serious problems associated with the long-term isolation of radioactive wastes is the subsurface migration of radionuclides. This migration depends on the chemical forms of the radionuclides. For example, $\mathrm{Pu}^{+6}$ is known to migrate through soil at a much faster rate than $\mathrm{Pu}^{+4}$. Similarly, $\mathrm{U}^{+6}$ migrates faster than $\mathrm{U}^{+4}$, and ${ }^{99} \mathrm{Tc}$ migrates more rapidly as the pertechnetate ion than it does in the reduced form. The practice of burying decontaminating agents with radioactive waste supplies complexing ligands for radionuclides which may enhance their ability to migrate at an early time. Though initially not present in some burial locations, complexed radionuclides may be generated by bacterial degradation during the long-term isolation of organic materials admixed with the radioactive waste. This could provide a possible means for future migration of radionuclides.

As recently as a year ago, very little definitive information was available on radionuclide movement at Maxey Flats, and there had been only two reasonably good indications of subsurface movement of radionuclides there. One case was the apparent movement of tritium and other radionuclides from one of the waste burial trenches to a well drilled a few meters from the burial trench. A second case was observed when a trench was dug adjacent to a waste burial trench near the southeast corner of the site. There, radioisotopes were detected in a smal1 amount of moisture seeping through a crack in the sandstone layer about $7 \mathrm{~m}$ (20 feet) below the ground surface. Small concentrations of radionuclides presumed to be from the site were reported following the Kentucky Department for Human Resources "Six Month Study" in 1974, but the mechanism for translocation was not understood. However, a compelling need to determine this mechanism emerged, and today we recognize that it is essential to understand all aspects of this important part of waste management. 


\section{RESEARCH OBJECTIVES}

The objectives of this research are fourfold: I) to determine the amounts and chemical species of radionuclides which are moved by subsurface routes; 2) to determine the areal distribution of radionuclides at the waste burial sites and over adjacent areas; 3) to compare the chemical species of radionuclides in waste burial trenches with those observed in monitoring trenches and wells, in springs or seeps, and in surface flow from the sites; and 4) to coordinate implementation of the above objectives with the implementation of the objectives of closely related programs underway or planned at the waste burial sites. Our initial research will be concentrated on the Maxey Flats waste disposal site.

In formulating our research program, we are reminded that the U. S. Nuclear Regulatory Commission (NRC) objectives include the need to 1) determine guidelines for the operation of existing waste burial sites; 2) develop recommendations for remedial actions at existing sites and for their eventual decommissioning; 3) identify the need for long-term surveillance and maintenance at the existing sites; and 4) develop site selection criteria for future waste burial sites. Furthermore, the research at Maxey Flats witl provide the information required by the Commonwealth of Kentucky for planning and conducting the ultimate closure of the Maxey Flats site.

\section{EXPERIMENTAL TRENCH}

Because of the small amount of definitive information on radionuclide movement at Maxey Flats, a program to define subsurface movement of radioriuclides has been given a very high priority. The method chosen to define radionuclide movement was to construct a slit trench adjacent to one or more existing waste burial trenches. By incorporating means of sampling water movement by saturated and unsaturated flow, a great deal of information could be obtained relative to the mechanisms of subsurface migration of radionuclides. Because of the relationship of trench capping techniques to infiltration of water into the waste burial trenches, it was also decided to include engineering studies of trench capping and surface drainage in the slit trench experiment. 


\section{Site Selection}

The hydrology and hydrogeology of the Maxey Flats site have been studied extensively by the U. S. Geological Survey. In addition, Dames and Moore have conducted a detaited survey of radioactivity levels over the site and have produced a topographic map in one-foot contours over the restricted area. Their findings were very useful in evaluating several candidate locations for the experimental trench, which has been constructed near the southwest corner of the burial site parallel to waste-filled trench \#27 (Figure 1).

\section{Trench Design}

The trench design required input from each of the raboratories who would participate in the slit trench experiment. The research tasks to be performed required the installation of sumps and porous cups to permit sampling for study of saturated flow. Porous cups were installed to monitor nonradioactive tracer movement from the experimental trench and through the various trench caps that would be evaluated. Porous cups and soil moisture cells were installed in the trench wall, cap, and adjacent area to study unsaturated flow near the experimental trench. Nonradioactive tracers were installed in the trench caps to study the permeability of the caps to water flow and to penetration by vegetation planted on the caps. Two sections of the experimental trench were capped with experimental caps that incorporated diffusion barriers. The completed trench was flanked by two drainage ditches to control erosion of the surface.

The final design was a trench $100 \mathrm{~m}$ long, excavated in five approximately equal sections separated from each other by unexcavated pillars 3-5 m long. Each section of the experimental trench was 1.5-2 m wide and 7-8 $\mathrm{m}$ deep. The segmented design was chosen to permit researchers to conduct a wider variety of experiments, and to evaluate and compare several different trench caps. In addition, the unexcavated pillars would serve as natural shoring 
posts to limit the potential for cave-ins during construction. crushed rock was chosen for backfilling the trench, and the trench caps chosen include clay (three sections), clay plus Hypalon barrier (one section), and clay plus Flintkote-coated Mirafi-140 barrier (one section). A final clay cap was common to all five trench sections.

\section{Trench Construction}

Some of the details of trench construction are summarized in the following paragraphs. Prior to excavation, the experimental trench location was auger-drilled and core-drilled to assure that excavation would not intercept any unrecorded buried radioactive waste. The material removed by the drill was constantly monitored for radioactivity during this work. The drilling activity also provided information on the material we would have to excavate to construct the slit trench. For example, it was determined that we would have to remove 2-3 m of overburden (mostly in the form of large sandstone blocks) before the slit trench excavation could be accomplished. This effort required the use of heavy construction equipment, and again constant monitoring for radioactivity was performed as one of the continuing safety measures employed.

Other construction work performed during the drilling and overburden removal included the assembly of two shoring cages to be used during entry into the excavated trench and the assembly of a large number of portable rain shields to be emplaced over the trenches to 1 imit entry of rainwater into the open trenches. Special equipment used onsite during the open phase included safety harnesses and lines, emergency air supply and fresh air masks, and ropes to discourage access to the edge of the trench. Radiation detection instruments were manned continually during the construction.

The experimental trench excavation was accomplished with a large backhoe capable of reaching the depth of the sandstone layer, as determined from the preliminary drilling (about $8 \mathrm{~m}$ below 
existing grade). Three of the trench sections excavated were about $1.5 \mathrm{~m}$ wide and two of the trench sections were up to $2 \mathrm{~m}$ wide to accormodate the long hand augers used to drill holes in the trench wall for porous cup and soil moisture cell emplacements. Following installation of sumps, porous cups, soil moisture cells, and a nonradioactive tracer, the trenches were backfilled with crushed rock and capped with clay or clay plus diffusion barriers. Various nonradioactive tracers were added to the trench cap to monitor the integrity of the different cap designs. Similarly, nonradioactive tracers were incorporated into the caps emplaced on two trench sections to study the permeability of these caps to shallow and deeprooted plants. The various activities and installations are summarized in Table I.

Each planned activity to be accomplished during the trench construction was conducted, although some curtailments were necessary because of changing safety constraints imposed by the nature of the excavated trench walls and the prolonged heavy rains during construction. Thus only a small part of the geologic fracture logging within the excavated trenches was possible. Similarly, about half of the planned gamma-ray logging was performed, although grab samples were obtained and later analyzed for radionuclide content. Future projects of this nature should be planned with these possibilities in mind. Under weather conditions like those encountered during this construction, it would be desirable to limit the amount of open trench during any given time to maximize the degree of $\mathrm{co-}$ ordination possible.

IV. WATER AND SOIL SAMPLES DURING AND AFTER TRENCH CONSTRUCTION

Water flowed into three sections of the experimental trench during construction and samples were taken for radionuclide analysis. The initial radioactive concentrations were comparable to trench leachate from waste trench 27 for ${ }^{3} \mathrm{H}$ and ${ }^{90} \mathrm{Sr}$, and somewhat lower for the other radionuclides. On several subsequent sampling trips to Maxey Flats, water was collected from the sumps for radionuclide analysis. The analytical results for ${ }^{3} \mathrm{H}$, plutonium, ${ }^{90} \mathrm{Sr},{ }^{60} \mathrm{Co}$, and ${ }^{137} \mathrm{Cs}$ are compared in Tables II through $V$. These radionuclides were easily measured in the samples taken during construction, but only ${ }^{3} \mathrm{H}$ 
and ${ }^{90} \mathrm{Sr}$ concentrations were high enough for easy detection in samples taken during sampling trips about one and six months later.

Soil samples were taken from each section of the experimental trench during construction and were analyzed for ${ }^{90} \mathrm{Sr}$, plutonium, and ${ }^{241} \mathrm{Am}$. The highest ${ }^{90} \mathrm{Sr}$ concentration was in a sample taken at the water level and may simply reflect ${ }^{90} \mathrm{Sr}$ adsorbed from trench inflow, as most ${ }^{90} \mathrm{Sr}$ concentrations were comparable to fallout levels. Piutonium concentrations were mostly low, with two samples having concentrations higher than fallout levels. Americium contents of two soil samples were slightly elevated, and prompted us to look at the surface soil immediately surrounding the experimental trench. These analyses are summarized in Table VII and concentrations are comparable to plutonium concentrations seen on site, al though not as variable.

The radionuclide concentrations measured in construction samples clearly show that subsurface movement of radionuclides has occurred at Maxey Flats, although no conclusions can be inferred from these data about distance from any of the radionuclide sources. The marked decrease in most radionuclide concentrations observed on resampling the experimental trench may indicate that the radionuclides were present initialiy only in the experimental trench location or that the trench design has adversely influenced the concentrations of radionuclides in water flowing toward the trench sumps. To investigate these possibilities, two experiments were performed with the crushed rock used to backfill the experimental trench. When the water that flowed into the experimental trench during construction was passed through columns of crushed rock, the effluent radionuclide concentrations were markedly lower than the starting concentrations. In a second experiment, trench leachate water was pumped from waste trench 27 through columns of crushed rock in the absence of oxygen. The crushed rock had no effect on radionuclide concentration in this second experiment, and the effluent was indistinguishable from the trench leachate. It is possible that the exposure of the open trench to air during construction may have resulted in the formation of an in-place scavenger (ferric hydroxide), which reacts synergistically with the crushed rock to form an absorptive barrier for radionuclide transport. 


\section{AREAL DISTRIBUTION OF RADIONUCLIDES}

In situ gamma-ray spectrometry was used to survey the site surface near the experimental trench during construction activities. Cobalt-60 and ${ }^{137} \mathrm{Cs}$ were measurabie at many counting locations, as were the naturallyoccurring radionuclides. The counting summary shown in Figure 2 illustrates the lack of correlation between surface concentrations of ${ }^{60} \mathrm{Co}$ and ${ }^{137} \mathrm{Cs}$. Soil samples taken from these areas showing high count rates were also analyzed for ${ }^{238} \mathrm{Pu},{ }^{241} \mathrm{Am}$, and ${ }^{90} \mathrm{Sr}$, and a similar lack of correlation was noted (Table VIII). These studies indicate that the in situ counting techniques, which are useful for measuring gamma-ray emitting radionuclides, may not necessarily predict where one might expect to find beta- or alphaemitting radionuclides at the Maxey Flats site, even though these radionuclides are all closely associated in trench leachate.

A second areal survey was performed recently, and preliminary results are summarized in Figure 3 . These data demonstrate that surface contamination has been retained largely within the fenced area at Maxey Flats. slightly elevated concentrations of ${ }^{60} \mathrm{Co}$ and ${ }^{137} \mathrm{Cs}$ were measured in only a few locations immediately outside the fenced area, notably those associated with drainage areas. The ${ }^{60} \mathrm{Co}$ concentrations measured on the west side are near the locations where elevated ${ }^{60} \mathrm{Co}$ levels were noted in vegetal samples. Background levels of ${ }^{137} \mathrm{Cs}$ around the fence are about $0.5 \mathrm{pCi} / \mathrm{gm}$ and in only two cases was the concentration higher than $1.5 \mathrm{pCi} / \mathrm{gm}$. Most ${ }^{60} \mathrm{Co}$ levels were near the levels noted for worldwide fallout, with the highest concentration outside the fence about $5 \mathrm{pCi} / \mathrm{gm}$. The count rates inside the fenced area were similar for ${ }^{137} \mathrm{Cs}$ and somewhat higher for ${ }^{60} \mathrm{Co}$, with the highest concentration of ${ }^{60} \mathrm{Co}$ about $15 \mathrm{pCi} / \mathrm{gm}$.

The counts plotted in Figures 2 and 3 represent integrated count rates from $5 \mathrm{~m}$ radius circular surface areas and therefore indicate average soil concentrations over those areas. Individual soil samples from each of these locations, when analyzed, may show different concentrations than are indicated from the in situ counting data. The counting data are, nevertheless, very useful in pointing out where further, more specific, study should occur. 
VI. CHEMICAL SPECIES OF MIGRATING RADIONUCLIDES

The initial determinations of the chemical species of radionuclides in trench inflow water were inconclusive because aging of the samples had taken place before they could be analyzed in the laboratory. Americium-241, ${ }^{137} \mathrm{Cs}$, and ${ }^{90} \mathrm{Sr}$ were present in cationic species at the time of analysis, and only a small fraction of the total ${ }^{60}$ Co present was anionic. Plutonium radionuclides were present in several forms and had become about half cationic, a fourth anionic, and a fourth nonionic. Physical changes had taken place in the samples (e.g., the tendency to form ferric hydroxide) and the changes could have altered the original ionic species.

The results of the first measurements underscored the need to make such separations as close to the water source as possible, in this case at the bottom of the sumps. Apparatus was prepared to permit ion exchange separations and solvent extraction separations to be conducted anoxically at the source of the water. The analyses of water samples separated in this manner are summarized in Tables $I X$ and $X$. Americium-241 and ${ }^{137} C_{S}$ were not measurable in the sump solutions because of the low concentrations that now are present for these radionuclides. Cobalt-60 was present in anionic species, in conformance with its known characteristics. Plutonium was present primarily as anionic species, al though some cationic species were present or were produced by competition between the plutonium complex and the cation resin.

Solvent extractions were performed concurrently with the ion exchange experiments using an extractant noted for its strong complex with tetravalent plutonium. None of the plutonium which passed through the anion resin column was extractable with thenoyl trifluoroacetone (TTA) in xylene. About $25 \%$ of the plutonium in the effluent from the cation resin column could be extracted, indicating that the ITA could compete favorably for some of the complexed plutonium. The results of the solvent extraction and ion exchange experiment indicate that the existing plutonium complex in the sump water is present primarily as an ionic species and it exists in trivalent and tetravalent forms.

VII. CONCLUSIONS

In situ gamma-ray spectrometry was demonstrated to be usefui for mapping radionuclide distributions of gamma-ray emitting radionuclides at Maxey Flats, 
but distributions of alpha- and beta-emitting radionuclides must be determined from soil sample analyses. The surveys conducted illustrate that surface contamination at Maxey Flats is largely contained within the fenced area. Additional survey work is planned in the drainage channels outside the fence.

The subsurface movement of radionuclides to the sumps of the experimental trench is impeded by the materials used in trench construction, by the prolonged effect of oxygen on the trench inflow water, or both. Consequently, it is necessary to install monitoring wells near the experimental trench to collect anoxic water samples from which chemical species determinations can be made (Figure 2). The wells will permit measurement of flow through undisturbed soil and provide the means to make a better evaluation of the extent and rate of migration of radionuclides at Maxey Flats. Cores will also be obtained for distribution coefficient measurements.

Plutonium exists in subsurface water entering the experimental trench mostly in the reduced forms. It is both trivalent and tetravalent, apparently strongly complexed, and exists mostly in anionic species. Continuing research on chemical species will provide related information for plutonium and other radionuclides in water from monitoring wells, waste trenches, surface runoff, and springs or seeps outside the fenced area. 
TABLE T

MAXEY FLATS EXPERIMENTAL TRENCH SUMMARY

\begin{tabular}{|c|c|c|c|c|c|}
\hline & & & ENCH SECTION & & \\
\hline & $\mathrm{T}-1$ & $T-2$ & $\mathrm{~T}-3$ & $T-4$ & $\mathrm{~T} .5$ \\
\hline GAMMA-RAY LOGGING & PARTIAL & YES & No & YES & No \\
\hline GEOLOGIC LOGGING & NO & PARTIAL & NO & NO & No \\
\hline WATER IN-FLOW & YES & YES & YES & $?$ & $?$ \\
\hline SUMPS & 2 & 2 & 2 & 1 & 1 \\
\hline POROUS CUPS & 3 & 3 & 3 & 3 & 3 \\
\hline $\begin{array}{l}\text { POROUS CUPS } \\
\text { IN TRENCH WALL. }\end{array}$ & - & - & - & $\begin{array}{l}\text { THREE VERTICAL } \\
\text { TRAVERSES + CAP }\end{array}$ & - \\
\hline $\begin{array}{l}\text { SOIL MOISTURE CELLS } \\
\text { IN TRENCH WALL }\end{array}$ & - & . & - & $\begin{array}{l}\text { ONE VERTICAL } \\
\text { TRAVERSE + CAP }\end{array}$ & . \\
\hline CAP DESIGN & $\begin{array}{l}\text { LOCAL SOIL } \\
\text { CLAY }\end{array}$ & $\begin{array}{l}\text { LOCAL SOIL } \\
\text { CLAY }\end{array}$ & $\begin{array}{l}\text { LOCAL SOIL, } \\
\text { MIRAFI-140 } \\
\text { CLAY }\end{array}$ & $\begin{array}{l}\text { LOCAL SOIL } \\
\text { CLAY }\end{array}$ & $\begin{array}{l}\text { CLAY } \\
\text { HYPALON } \\
\text { CLAY }\end{array}$ \\
\hline DEEP TRACER & $\mathrm{NaBr}$ & $\mathrm{NaBr}$ & $\mathrm{NaBr}$ & No & $\mathrm{NaBr}$ \\
\hline CAP TRACERS & $\begin{array}{l}\mathrm{NaBENZOATE} \\
\mathrm{BaCl}_{2} \\
\mathrm{NiSO}_{4}\end{array}$ & $\begin{array}{l}\text { O-FLUORO- } \\
\text { BENZOIC ACID } \\
\mathrm{Sr}\left(\mathrm{NO}_{3}\right)_{2} \\
\mathrm{Li}_{2} \mathrm{CO}_{3}\end{array}$ & NaBENZOATE & $\begin{array}{l}\text { PENTA FLUORO. } \\
\text { BENZOIC ACIO }\end{array}$ & NaBENZOATE \\
\hline
\end{tabular}

DRAINAGE DITCHES

DRAIN TRENCH CAP FOR TRACER STUDIES AND EROSION CONTROL

GROUND TRACER P-FLUOROBENZOIC ACID SPREAD ON GROUND SOUTH OF T-3 
TABLE 2

$\frac{\text { Iritium Concentrations in Experimental Trench Water }}{\mathrm{pCi} / \ell}$

Location

$T-1 E$

$T-1 W$

$T-2 E$

$T-2 W$

$\mathrm{T}-3 \mathrm{E}$

T-3W

T-4

T-5

State Park

TABLE 3

Plutonium Concentrations in Experimental Trench Water $\mathrm{pCi} / \ell$

Location

T-IE

T-IW

T-2E

$T-2 W$

$\mathrm{T}-3 \mathrm{E}$

$T-3 W$

\begin{tabular}{ccc}
$\begin{array}{c}\text { Construction } \\
\text { Inflow }\end{array}$ & $\begin{array}{c}\text { November } \\
1979\end{array}$ & Apri1 1980 \\
\cline { 2 - 3 } $3.71 \times 10^{8}$ & $\begin{array}{c}4.42 \times 10^{8} \\
2.94 \times 10^{8}\end{array}$ & $2.69 \times 10^{8}$ \\
$1.67 \times 10^{9}$ & $6.50 \times 10^{8}$ & $4.80 \times 10^{8}$ \\
$4.20 \times 10^{9}$ & $1.46 \times 10^{9}$ & $5.06 \times 10^{8}$ \\
$3.35 \times 10^{9}$ & $5.56 \times 10^{7}$ & \\
& $2.50 \times 10^{7}$ & $4.90 \times 10^{6}$ \\
& $1.59 \times 10^{5}$ & \\
& $2.26 \times 10^{4}$ & \\
& $<600$ &
\end{tabular}

\begin{tabular}{lccc} 
Location & $\begin{array}{c}\text { Construction Flow } \\
\text { Inflow }\end{array}$ & $\begin{array}{c}\text { November } \\
1979\end{array}$ & Apri1 1980 \\
\cline { 2 - 3 } T-1E & 36 & 47 & 15 \\
T-TW & 61 & 38 & 8.5 \\
T-2E & $3.37 \times 10^{3}$ & 103 & \\
T-2W & $4.96 \times 10^{3}$ & 320 & \\
T-3E & & 38 & 0.2 \\
T-3W & & 66 &
\end{tabular}


TABLE 4

${ }^{90} \mathrm{Sr}$ Concentrations in Experimental Trench Water

$\mathrm{pCi} / \ell$

\begin{tabular}{cccc} 
Location & $\begin{array}{c}\text { Construction } \\
\text { Inflow }\end{array}$ & -1979 & Apri] 1980 \\
\cline { 2 - 4 } T-1E & $6.69 \times 10^{3}$ & $1.52 \times 10^{4}$ & $7.98 \times 10^{3}$ \\
T-1W & & $1.28 \times 10^{4}$ & \\
T-2E & $1.66 \times 10^{5}$ & $2.26 \times 10^{4}$ & $1.28 \times 10^{4}$ \\
T-2W & $1.62 \times 10^{5}$ & $2.91 \times 10^{4}$ & $1.80 \times 10^{4}$ \\
$T-3 E$ & $1.11 \times 10^{5}$ & 870 & $<350$ \\
$T-3 W$ & & 1500 & \\
$T-4$ & & 600 & \\
$T-5$ & & 56 &
\end{tabular}

TABLE 5

${ }^{60} \mathrm{Co}$ and ${ }^{137} \mathrm{Cs}$ Concentrations in Experimental Trench Water

$\mathrm{pCi} / \ell$

Construction

Location

Inflow

November

1979

Apri1 1980

${ }^{60} \mathrm{Co}$

T- IE

36

$\mathrm{T}-2 \mathrm{E}$

223

$T-2 W$

9680

$\mathrm{T}-3 \mathrm{E}$

6010

$T-3 W$

$T-1 E$

$T-2 E$

$T-2 W$

$\mathrm{T}-3 \mathrm{E}$

$T-3 W$

*Below detection level

65

1550

4600

90

$\begin{aligned} \star & \text { * } \\ \star & \text { * } \\ 18 & \text { * } \\ 40 & \text { * }\end{aligned}$

${ }^{137} \mathrm{Cs}$
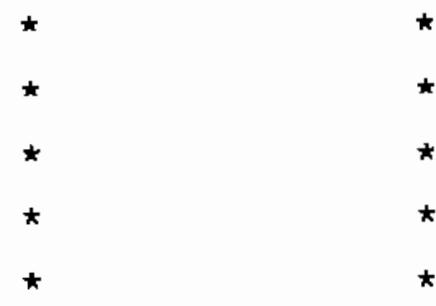

$\star$

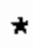

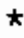

*

IV -12 
TABLE 6

SOIL SAMPLES TAKEN OURING CONSTRUCTION

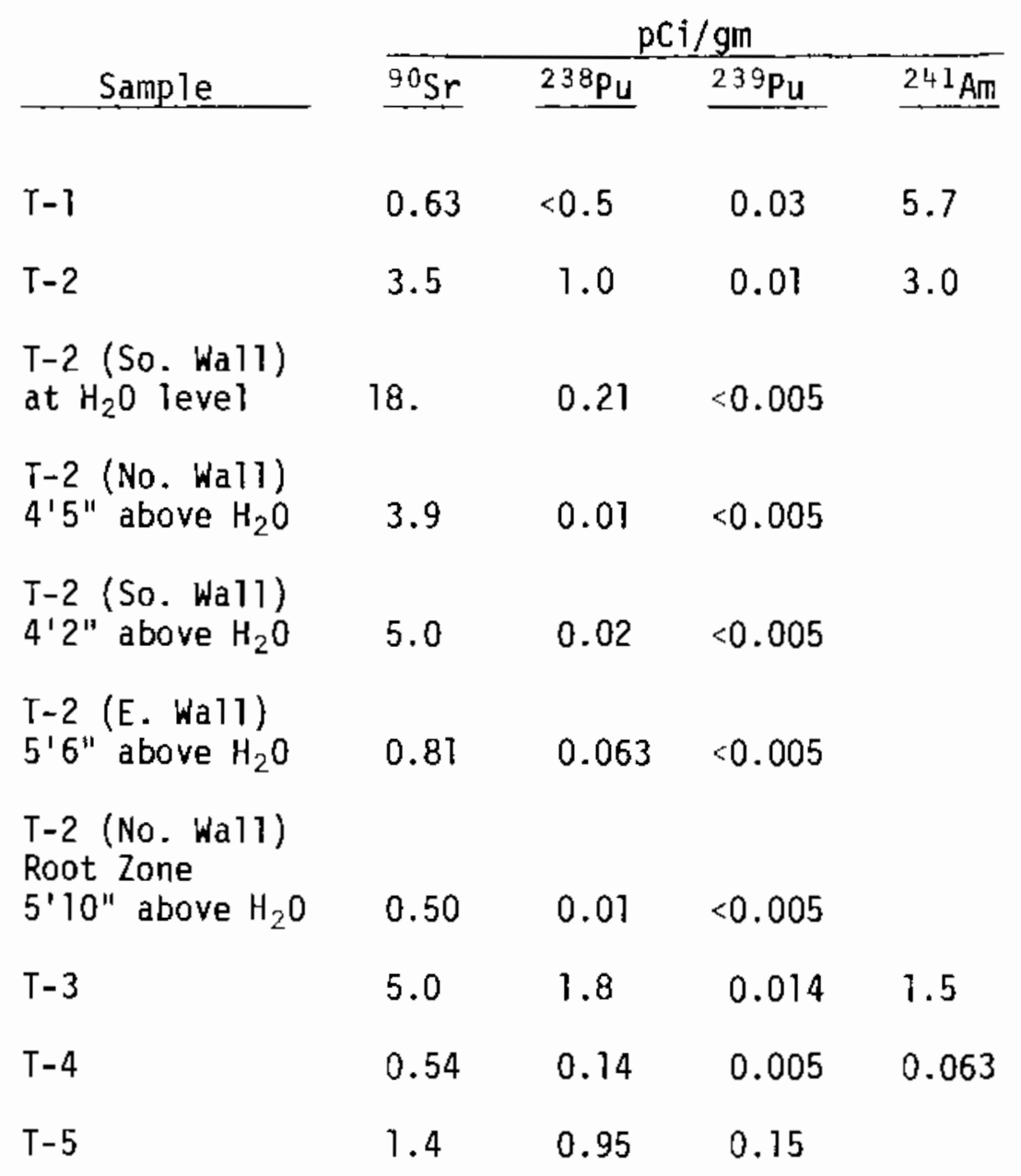




\section{TABLE 7}

241Am CONTENSS OF SURFACE SOLLS

$\begin{array}{lc}\begin{array}{l}\text { Sample Location } \\ \begin{array}{c}\text { Drainage channel by } \\ \text { south gate }\end{array} \\ \text { N060 W435 }\end{array} & <0.13 \\ \text { N060 W425 } & 0.5 \pm 0.1 \\ \text { N060 W415 } & 0.5 \pm 0.08 \\ \text { N060 W405 } & 0.6 \pm 0.1 \\ \text { N065 W375 } & 0.9 \pm 0.1 \\ \text { N065 W365 } & 0.6 \pm 0.08 \\ \text { N065 W355 } & 0.4 \pm 0.07 \\ \text { N065 W345 } & 0.3 \pm 0.06 \\ \text { N065 W335 } & 0.6 \pm 0.07 \\ \text { N070 W330 } & 1.3 \pm 0.1 \\ \text { N080 W340 } & 0.4 \pm 0.05\end{array}$

TABLE 8

MAXEY FLATS SOIL SAMPLES (10-7-79)

\begin{tabular}{|c|c|c|c|}
\hline \multirow[b]{2}{*}{ Location } & \multicolumn{3}{|c|}{$\mathrm{pCi} / \mathrm{gm}$} \\
\hline & $9^{90} \mathrm{Sr}$ & ${ }^{238} \mathrm{Pu}$ & $241 \mathrm{Am}$ \\
\hline N090 W330 & $0.88 \pm 0.063$ & $0.53 \pm 0.18$ & $0.23 \pm 0.11$ \\
\hline N090 W350 & $0.61 \pm 0.041$ & $0.66 \pm 0.0050$ & $0.16 \pm 0.023$ \\
\hline N090 W360 & $0.48 \pm 0.036$ & $0.91 \pm 0.25$ & $0.18 \pm .0050$ \\
\hline N090 W370 & $2.3 \pm 0.086$ & $14 \pm 1.4$ & $1.2 \pm 0.34$ \\
\hline N090 W390 & $1.1 \pm 0.059$ & $0.62 \pm 0.062$ & $0.40 \pm 0.059$ \\
\hline Ni00 W330 & $0.07 \pm 0.036$ & $0.69 \pm 0.069$ & $1.7 \pm 0.27$ \\
\hline
\end{tabular}


TABLE 9

CHEMICAL SPECIES OF RADIONUCLIDES IN EXPERIMENTAL TRENCH

(Experimental Trench Section T-2, 4-10-80)

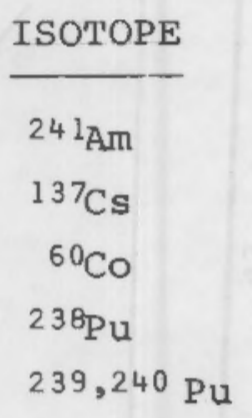

CATION

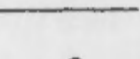

$<3$

$<1.4$

$<1$

2.3

0.3

TABLE 10

CHEMICAL SPECIES OF PLUTONIUM IN EXPERIMENTAL TRENCH

(Experimental Trench Section T-2, 4-10-80)

$\mathrm{pCi} /$
$239,240 \mathrm{Pu}$

Cation Resin Fraction

0.3

2

Anion Resin Fraction

Trivalent

0.2

5

Tetravalent

Particulate Fraction
ANION

$<2$

$<1.3$

2.5

12.5

0.3

0.1

$<0.1$

$<0.1$

$<0.1$
0.1 
MAXEY FLATS WASTE DISPOSAL SITE

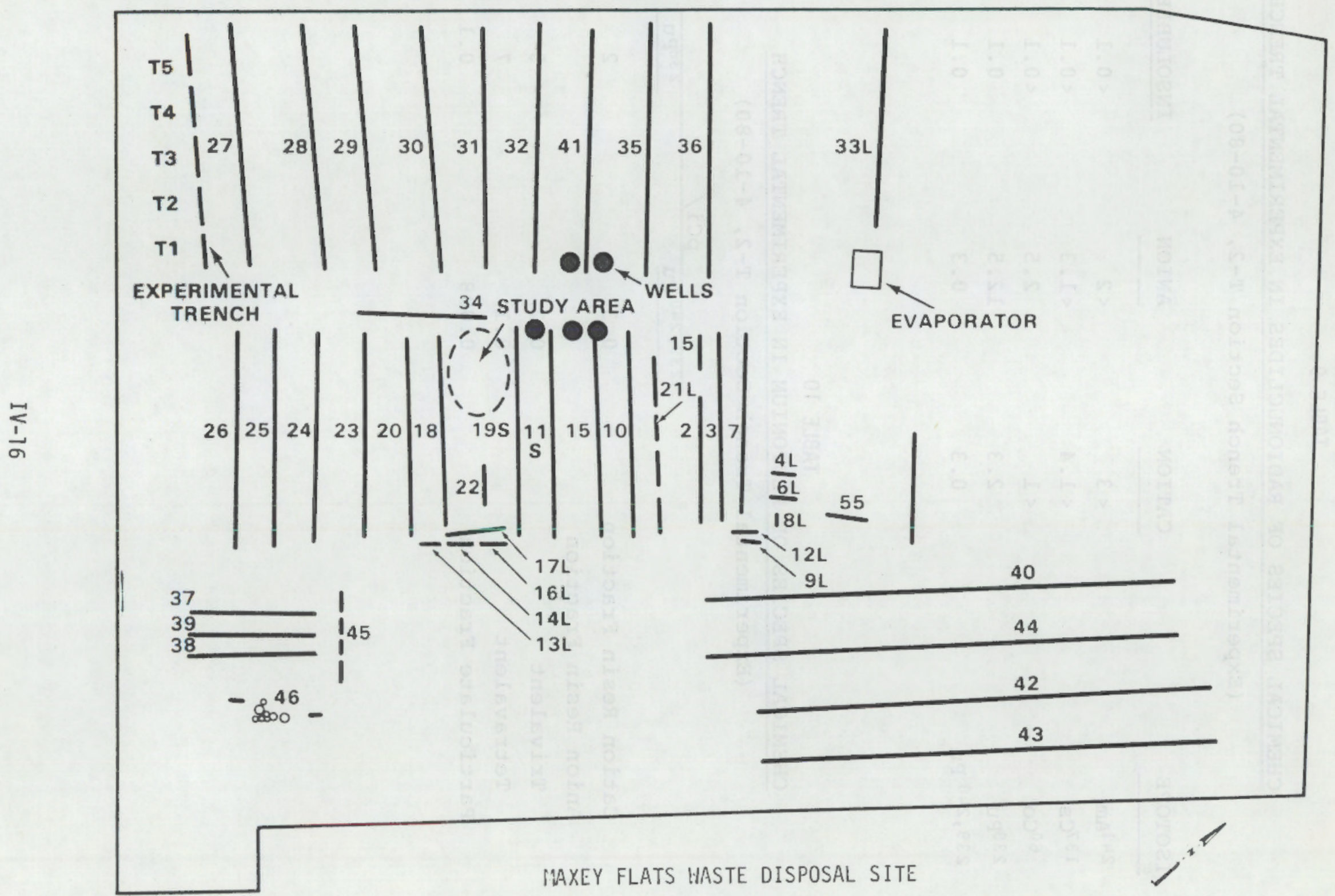

FIGURE । 


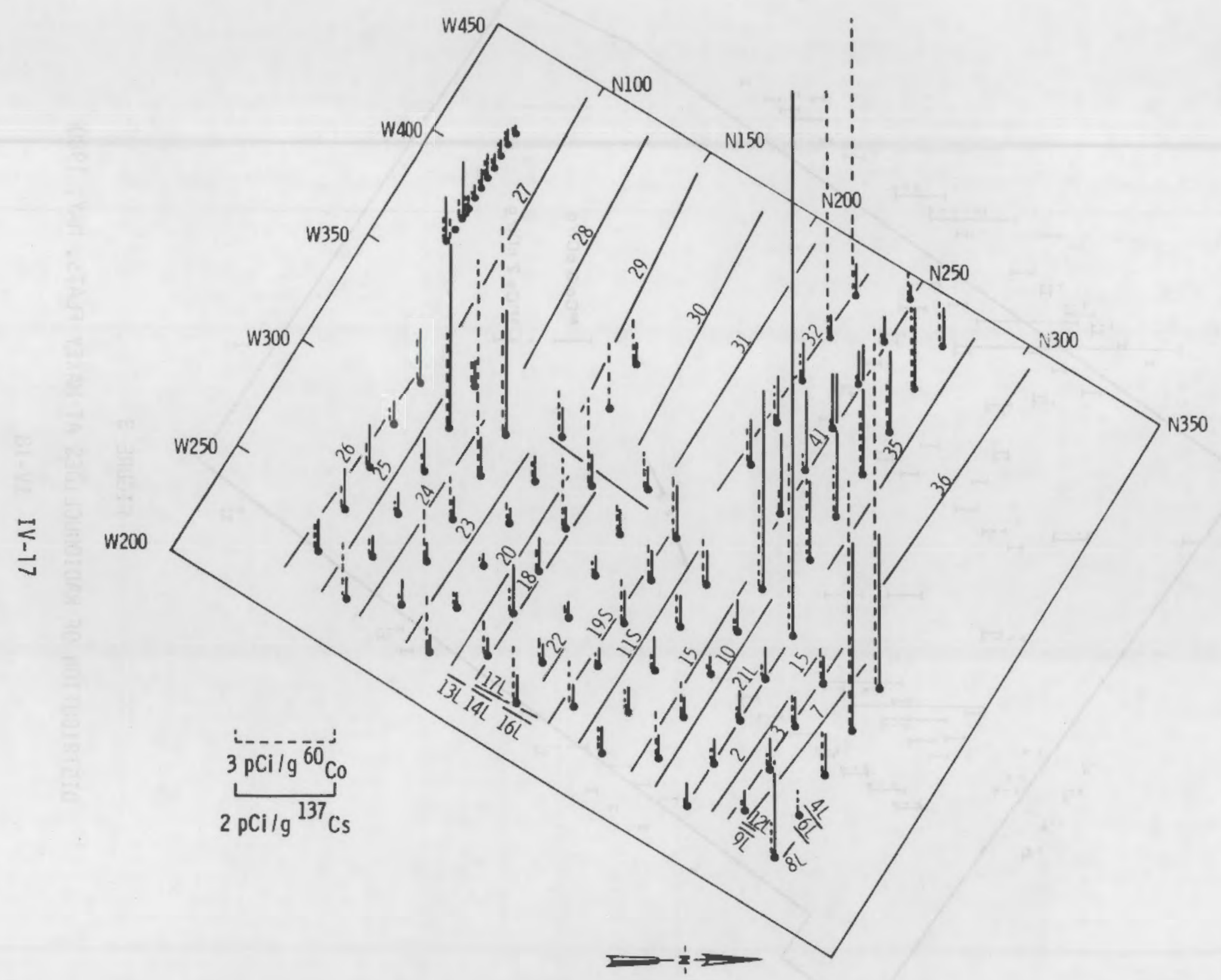

FIGURE 2

DISTRIBUTION OF RADIONUCLIDES AT MAXEY FLATS, OCTOBER, 1979 


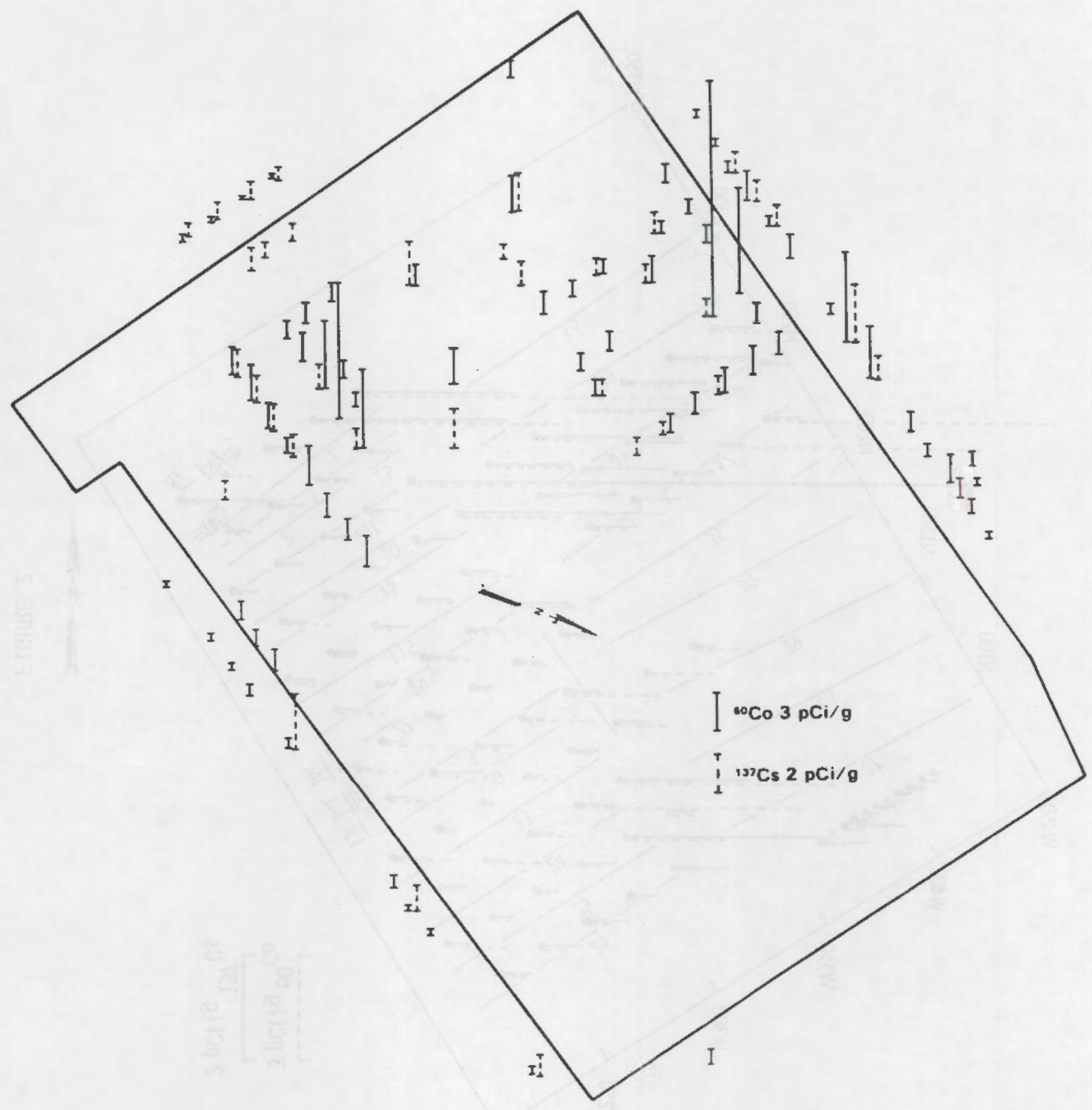

FIGURE 3

DISTRIBUTION OF RADIONUCLIDES AT MAXEY FLATS, MAY, 1980 


\section{SECTION $V$}

\section{RADIOECOLOGY STUDIES AT MAXEY FLATS, KENTUCKY: RADIONUCLIDES IN VEGETAL SAMPLES}

Pacific Northwest Laboratory

Richland, Washington 99352 
Radioecology Studies at Maxey Flats, Kentucky:

Radionuclides in Vegetal Samples

W. H. Rickard, L. J. Kirby and M. C. McShane

Pacific Northwest Laboratory

Richland, Washington

Ju7y, 1980

\section{SUMMARY}

Vegetal samples were collected on-site, near-site and moderately remote from the Maxey Flats waste disposal facility and radiochemically analyzed for 17 radionuclides. Only nine radionuclides were present in amounts that could be quantified. These were the naturally occurring (endogenous) radionuclides ${ }^{228} \mathrm{Th},{ }^{226} \mathrm{Ra},{ }^{7} \mathrm{Be}$ and ${ }^{40} \mathrm{~K}$. Exogenous (man-induced) radionuclides were also associated with the samples. These were ${ }^{144} \mathrm{Ce},{ }^{137} \mathrm{Cs},{ }^{125} \mathrm{Sb},{ }^{54} \mathrm{Mn}$ and ${ }^{60} \mathrm{Co}$. only ${ }^{60}$ Co appeared to be derived from the disposal site itself. Elevated levels of ${ }^{60}$ Co were observed in forest floor litter, in newly fallen leaves and in newly opened hickory leaves along the western boundary of the site. The amount of ${ }^{60}$ Co in vegetal samples is exceedingly small and appears to be derived from the rooting substrate by hickory trees but more sampling is needed to more clearly define the source of ${ }^{60}$ Co contamination in the forest. 


\section{Introduction}

The purpose of this task was to determine if radionuclides associated with shallow land burial at the Maxey Flats disposal site have migrated to the nearby forest. Two possible routes of radionuclide transport were considered: 1) The airborne vapor plume from the evaporator facjlity, 2) ground water or surface water movement in conjunction with root uptake by trees.

Methods

Previous experience in atmospheric transport of radionuclides from stack releases has shown the forest floor acts as a sink for man-induced radionuclides. The Maxey Flats vegetal survey strategy was simply to distribute sample points at different distances and directions from the evaporator stack (Figure 1). Samples of forest floor litter were harvested by hand from eighteen $0.32 \mathrm{~m}^{2}$ circular plots. The collected litter was placed in plastic bags for transport to the laboratory, oven dried in paper bags at $50-60^{\circ} \mathrm{C}$, milled and radiochemically analyzed for seventeen gamma-emitting radionuclides by gamma spectrometry. The forest floor sampling was done in late September, 1979 when leaves were still on the trees and the fallen leaves were on the forest floor in various stages of decomposition. A second visit was made to the same 18 places after the autumnal leaf fall event. Only newly fallen leaves were taken at this visit. Circular plots $0.66 \mathrm{~m}^{2}$ were hand harvested and treated in the same way as the forest floor litter samples. At the same time six other samples were taken from two different forest stands located nine miles east and nine miles west of the Maxey Flats disposal site. In late Apri1, 1980, the newly opened leaves of hickory and maple trees were picked from the low growing branches of trees growing near the waste disposal site. These were oven dried and treated in the same fashion as litter and newly fallen leaves. Three samples of surface soil were also collected at sites 4,5 and 6 (Figure 1). 
Results

Oniy nine of seventeen radionuclides were present in amounts that provided estimates of counting error. Beryllium-7, ${ }^{228} \mathrm{Th},{ }^{40} \mathrm{~K}$ and ${ }^{226}$ Ra were identified and measured in forest floor litter and in newly fallen leaves. These are naturally occurring (endogenous) radionuclides that are ubiquitously present in soils and vegetation throughout the world. Man-induced (exogenous) radionuclides were also measured in forest floor litter and new fallen leaves. These were ${ }^{137} \mathrm{Cs}$, ${ }^{144} \mathrm{Ce},{ }^{125} \mathrm{Sb},{ }^{54} \mathrm{Mn}$ and ${ }^{60} \mathrm{Co}$. These are mostly derived from nuclear weapon's tests and have been widely distributed by global scale atmospheric transport mechanisms. The distribution of these radionuclides (except ${ }^{60} C_{0}$ ) in the 18 forest floor samples is shown in Figures 2 and 3 . The endogenous radionuclides arranged in descending order of abundance were ${ }^{7} \mathrm{Be}>{ }^{40} \mathrm{~K},>{ }^{226} \mathrm{Ra}>{ }^{228} \mathrm{Th}$. The exogenous radionuclides, except ${ }^{60} \mathrm{Co}$, arranged in decreasing order of abundance were ${ }^{144} \mathrm{Ce},>{ }^{137} \mathrm{Cs},>{ }^{125} \mathrm{Sb}$ and $>{ }^{54} \mathrm{Mn}$. The concentration of radionuclides expressed as $\mathrm{d} / \mathrm{m} / \mathrm{g}$ dry wt. was greater in the forest floor litter than in newly fallen leaves (Figures 4 and 5 ). The amount of radionuclides expressed per square meter of forest floor was also greater because there was about four times more forest litter per unit area than newly fallen leaves (Table 1). The forest floor litter acted as a sink for the exogenous radionuclides with 37 times more ${ }^{137} \mathrm{Cs}$ in the forest floor litter than in the annual input of new fallen leaves. Cerium-144 and ${ }^{125}$ Sb were also much more abundant in the forest floor litter than in new fallen leaves indicating that the forest floor acts as a sink for exogenous airborne radionuclides.

There was no indication that any of the exogenous radionuclides had originated from the radioactive materials buried at Maxey Flats. Samples of new fallen leaves collected 9 miles from the disposal site had essentially the same values as near-site samples (Table 2). 
Table 1. Average values of radionuclides in forest floor 1 itter and newly fallen leaves, Maxey Flats, KY, 1979

\begin{tabular}{|c|c|c|c|c|}
\hline & $\begin{array}{c}\text { Forest Floor } \\
\text { Litter }\end{array}$ & $\begin{array}{c}\text { Newly Fallen } \\
\text { Leaves }\end{array}$ & $\begin{array}{c}\text { Ratio } \\
\text { Litter/Leaves } \\
\end{array}$ & \\
\hline \multicolumn{5}{|c|}{$\mathrm{d} / \mathrm{m} / \mathrm{gram} \mathrm{dry} w \mathrm{t}$} \\
\hline${ }^{7} \mathrm{Be}$ & 14. & 8.0 & 1.75 & \\
\hline${ }^{228}$ Th & .48 & .26 & 1.85 & Endogenous \\
\hline $40_{K}$ & 4.4 & 3.9 & 1.13 & Radionuclides \\
\hline${ }^{226} \mathrm{Ra}$ & 1.4 & .40 & 3.50 & \\
\hline $137 \mathrm{Cs}$ & 3.5 & .36 & 9.72 & \\
\hline${ }^{144} \mathrm{Ce}$ & 4.2 & .30 & 14.0 & Exogenous \\
\hline${ }^{125} \mathrm{Sb}$ & .46 & .064 & 7.18 & Radionuclides \\
\hline${ }^{54} \mathrm{Mn}$ & .056 & .017 & 3.29 & \\
\hline \multicolumn{5}{|c|}{$d / m / m^{2}$} \\
\hline${ }^{7} \mathrm{Be}$ & 15,708 & 2,360 & 6.6 & \\
\hline${ }^{228}$ Th & 539 & 77 & 7.0 & Endogenous \\
\hline $40_{K}$ & 4,937 & 1,150 & 4.3 & Radionuclides \\
\hline${ }^{226} \mathrm{Ra}$ & 1,570 & 118 & 13. & \\
\hline${ }^{137} \mathrm{Cs}$ & 3,927 & 106 & 37 & \\
\hline${ }^{144} \mathrm{Ce}$ & 4,712 & 88 & 53 & Exogenous \\
\hline${ }^{125} \mathrm{Sb}$ & 516 & 19 & 27 & Radionuclides \\
\hline${ }^{54} \mathrm{Mn}$ & 63 & 5 & 13 & \\
\hline \multicolumn{5}{|c|}{ grams dry $w t / \mathrm{m}^{2}$} \\
\hline Dry matter $/ 9 / \mathrm{m}^{2}$ & $1,122+22$ & $295+9.4$ & 3.8 & \\
\hline
\end{tabular}


Table 2. Comparison of radionuclide content of newly fallen leaves near and remote from the Maxey Flats Disposal Facility.

\begin{tabular}{|c|c|c|c|}
\hline & Near-Site & Remote & \\
\hline & & wt. & \\
\hline${ }^{7} \mathrm{Be}$ & 8.0 & 9.0 & \\
\hline $40_{K}$ & 3.9 & 3.7 & Endogenous \\
\hline${ }^{226} \mathrm{Ra}$ & .40 & 1.3 & Radionuclides \\
\hline${ }^{228} \mathrm{Th}$ & .26 & .23 & \\
\hline${ }^{137} \mathrm{Cs}$ & .36 & . 45 & \\
\hline${ }^{144} \mathrm{Ce}$ & .30 & .41 & Exogenous \\
\hline${ }^{125} \mathrm{Sb}$ & .064 & $<.030$ & Radionuclides \\
\hline${ }^{54} \mathrm{Mn}$ & .017 & $<.010$ & \\
\hline
\end{tabular}


Cobalt-60

Cobalt-60 was not distributed over the 18 study plots in the same pattern as the other exogenous radionuclides (Figure 6). Sample collection sites 1,3 , 4,5 and 6 located in the proximity of the evaporator had the highest levels of ${ }^{60} \mathrm{Co}$. This suggests that the source of ${ }^{60}$ Co may be the vapor plume emanating from the evaporator facility. Sample sites 5 and $\epsilon$ also had the highest levels of ${ }^{60} \mathrm{Co}$ in new fallen leaves. If the vapor plume is the transport media, the ${ }^{60} \mathrm{Co}$ burden is probably surficial contamination delivered to the forest during the months May to November while the leaves are on the trees. Cobalt-60 attached to leaves is delivered to the forest floor at leaf fall. An alternative source of ${ }^{60}$ Co to the forest floor is contaminated subsojl and/or ground water within the root zones of trees near locations 5 and 6 (Figure 1). To help resolve the issue of whether the source of ${ }^{60} \mathrm{Co}$ detected in tree leaves is aerial deposition or root uptake from contaminated soil or ground water, additional sampling is necessary. It is not likely that the evaporator would be shut down during the 1980 growing season so that leaf samples could be taken without experiencing drift from the vapor plume. An alternative is to sample fresh, newly opened Jeaves for radiochemical analyses before they have had much time to accumulate airborne depositions.

Hewly opened spring leaves of hickory, Carya spp., and maple, Acer spp. , had more ${ }^{40} \mathrm{~K}$ than newly fallen autumn leaves (Table 3 ). This was expected because the stable potassium content of actively growing plant tissues is usually greater than senescent tissues. The ${ }^{228}$ Th content of hickory leaves was higher than that of maple leaves indicating that the mineral nutrient uptake of hickories is different than that of maples. The ${ }^{137} \mathrm{Cs}$ content of 
hickory leaves was also higher than in maple leaves (Table 3 ). One sample of hickory leaves showed elevated levels of ${ }^{60} \mathrm{Co}$ indicating that the source of ${ }^{60} \mathrm{Co}$ to tree leaves is probably through local contamination of the rooting substrate rather than through general widespread aerial contamination.

The ${ }^{40} \mathrm{~K}$ content of surface soil ranged between 23 and $28 \mathrm{~d} / \mathrm{m} / \mathrm{g}$ (Table 3 ). The ${ }^{228}$ Th and ${ }^{226} \mathrm{Ra}$ content of surface soil ranged between 2.5 and $2.6 \mathrm{~d} / \mathrm{m} / \mathrm{g}$. The ${ }^{7}$ Be content of soil was much lower than that of new leaves. The most abundant exogenous radionuclide in soil was ${ }^{137}$ Cs (Table 3 ). Its origin is probably worldwide fallout. The ${ }^{144} \mathrm{Ce},{ }^{125} \mathrm{Sb}$ and ${ }^{54}$ Mn contents of surface soil were very low. The ${ }^{60}$ Co content of surface soil was relatively high (Table 3 ) and this suggests that its source is from the burial ground rather than fallout. The ${ }^{60}$ Co content of the soil may be biologically induced by root uptake, leaf fall, leaf decomposition and subsequent local contamination of surface soil. The source of ${ }^{60}$ Co may also be surface water runoff. A single sample of fine sediment collected from the sides of a surface rill had the highest level of ${ }^{60} C_{0}$ contanination at $9.4 \mathrm{~d} / \mathrm{m} / \mathrm{g}$. The ${ }^{137} \mathrm{Cs}$ content was on $1 \mathrm{y} 2.1 \mathrm{~d} / \mathrm{m} / \mathrm{g}$. This suggests that surface water runoff is a means of radionuclide transport from the burial ground.

The chemical form of the ${ }^{60} \mathrm{Co}$ in 7 itter, senescent leaves, newly opened leaves and soil is unknown.

Other Radionuclides

Sufficient quantities of forest floor litter and new fallen leaves were collected so that radiochemical analyses can be performed to determine if other kinds of radionuclides are present, e.g., plutonium, americium and strontium, radionuclides that require different techniques of chemical analysis. 


\section{Pasture Grasses}

The land within the fenced boundaries of the disposal site supports no trees. Most of the land not devoted to buildings, roadways and other special uses has been planted to perennial pasture grasses. Grasses are planted over trench backfill and intervening areas and are periodically mowed. Grasses growing over trenches were harvested to provide plant material for radiochemical analyses. The data are briefly summarized in Tabie 4. There was no indication that ${ }^{60} \mathrm{Co},{ }^{125} \mathrm{Sb},{ }^{54} \mathrm{Mn},{ }^{137} \mathrm{Cs}$ or ${ }^{144} \mathrm{Ce}$ was introduced to the actively growing shoots via root penetration into buried waste. Vaiues for ${ }^{228} \mathrm{Th},{ }^{226} \mathrm{Ra}$ and ${ }^{7} \mathrm{Be}$ were similar to those of new fallen tree leaves. However, the ${ }^{40} k$ content of actively growing grass was 8 times greater than in the senescent tree leaves attributable to the high demand for potassium as an essential nutrient element in fast growing plant tissues. The short statured grasses are probably not as efficient at intercepting airborne particulates as are tall trees. The grass leaves are also not exposed as long as tree leaves because they are periodically mowed during the summer growing season. Grasses also have relatively shallow root systems as compared to trees and therefore are less likely to penetrate into buried wastes and bring radionuclides to the aboveground tissues.

\section{Continuing Studies}

The data so far indicate that hickory trees have the greatest affinity for ${ }^{60} \mathrm{Co}$ and that the source of ${ }^{60} \mathrm{Co}$ is probably through the rooting substrate. Autumn leaf fall collection seems to be the most economical way to collect leaves from different kinds of trees. It is proposed to place leaf fall collectors (trays, buckets or other suitable containers) beneath the canopy of mature trees, i.e., Carya spp., Acer spp., Quercus spp., in the forest around 
the Maxey Flats site in late September and collect them in late November after autumnal leaf fall. Trees would be located, individually numbered and mapped to provide a way to determine the areal extent of radionuclide migration from the burial site.

Food Chain Transport

The transport of radionuclides through the food chain from the forest ecosystem to man appears to be negligible. The plant species that comprise the forest are mostly unpalatable to people. Some wood may be used to smoke meat and fish and in this way some radionuclides may be added to foods. It is also possible that some tree sap from contaminated maple trees could be collected and processed into sugar. These, however, are unlikely sources of radionuclides in quantity. Wild animals that derive their foods from the forest and are eaten by people are possible sources of radionuclides. However, the forests at Maxey Flats are apparently not abundant with deer, squirrels or cottontajls or upland birds such as ruffed grouse, bobwhite quail or mourning doves, animals that are usually the important hunted species of the region. The wild animals most exposed to radionuclides in their foods are the detritovores such as microarthropods and earthworms that live in the forest floor litter. This suggests that animals not in the food chain to man that eat earthworms are the most likely radionuclide vectors, i.e., earthworm eating shrews, Sorex spp. and robins, Turdus migratorius. 
Table 3. Radionuclide content $d / m / g$ of newly opened tree leaves and surface soil, April, 1980.

\begin{tabular}{|c|c|c|c|c|c|}
\hline & ${ }^{137} \mathrm{Cs}$ & $\begin{array}{l}\text { Exogenous } \\
{ }^{144} \mathrm{Ce} \\
\end{array}$ & $\begin{array}{c}\text { Radionuclides } \\
{ }^{125} \mathrm{Sb}\end{array}$ & ${ }^{54} \mathrm{Mn}$ & ${ }^{60} \mathrm{Co}$ \\
\hline Hickory & .50 & $<.20$ & $<.10$ & $<.02$ & $<.05$ \\
\hline Hickory & .43 & $<.20$ & $<.10$ & .02 & 4.0 \\
\hline Hickory & .48 & $<.20$ & $<.10$ & .02 & .26 \\
\hline Maple & .14 & $<.20$ & $<.10$ & $<.02$ & $<.04$ \\
\hline Maple & .12 & $<.20$ & $<.10$ & $<.02$ & $<.03$ \\
\hline Maple & .24 & $<.20$ & $<.10$ & $<.02$ & .07 \\
\hline Soil & 4.9 & $<.10$ & .20 & .01 & 1.6 \\
\hline Soil & 4.3 & $<.10$ & .10 & .03 & .72 \\
\hline Soil & 5.2 & .20 & .10 & .03 & 1.0 \\
\hline
\end{tabular}

\begin{tabular}{|c|c|c|c|c|}
\hline & ${ }^{7} \mathrm{Be}$ & $\begin{array}{c}\text { Endogenous } \\
40 \mathrm{~K}\end{array}$ & $\begin{array}{l}\text { Radionuclides } \\
{ }^{228} \text { Th }\end{array}$ & ${ }^{228} \mathrm{Ra}$ \\
\hline Hickory & 1.7 & 46 & .15 & .20 \\
\hline Hickory & 1.5 & 52 & .19 & .30 \\
\hline Hickory & 1.3 & 36 & .15 & .30 \\
\hline Maple & 1.7 & 38 & $<.04$ & .10 \\
\hline Maple & 1.7 & 38 & $<.04$ & .10 \\
\hline Maple & 1.8 & 37 & $<.04$ & .20 \\
\hline Soj 1 & $<.20$ & 28 & 2.6 & 2.5 \\
\hline Soit & $<.20$ & 28 & 2.6 & 2.6 \\
\hline Soil & $<.20$ & 28 & 2.5 & 2.6 \\
\hline
\end{tabular}


Table 4. Radionuclide content $d / m / g$ dry wt. in live grass and newly fallen tree leaves (averages and range) 1979.

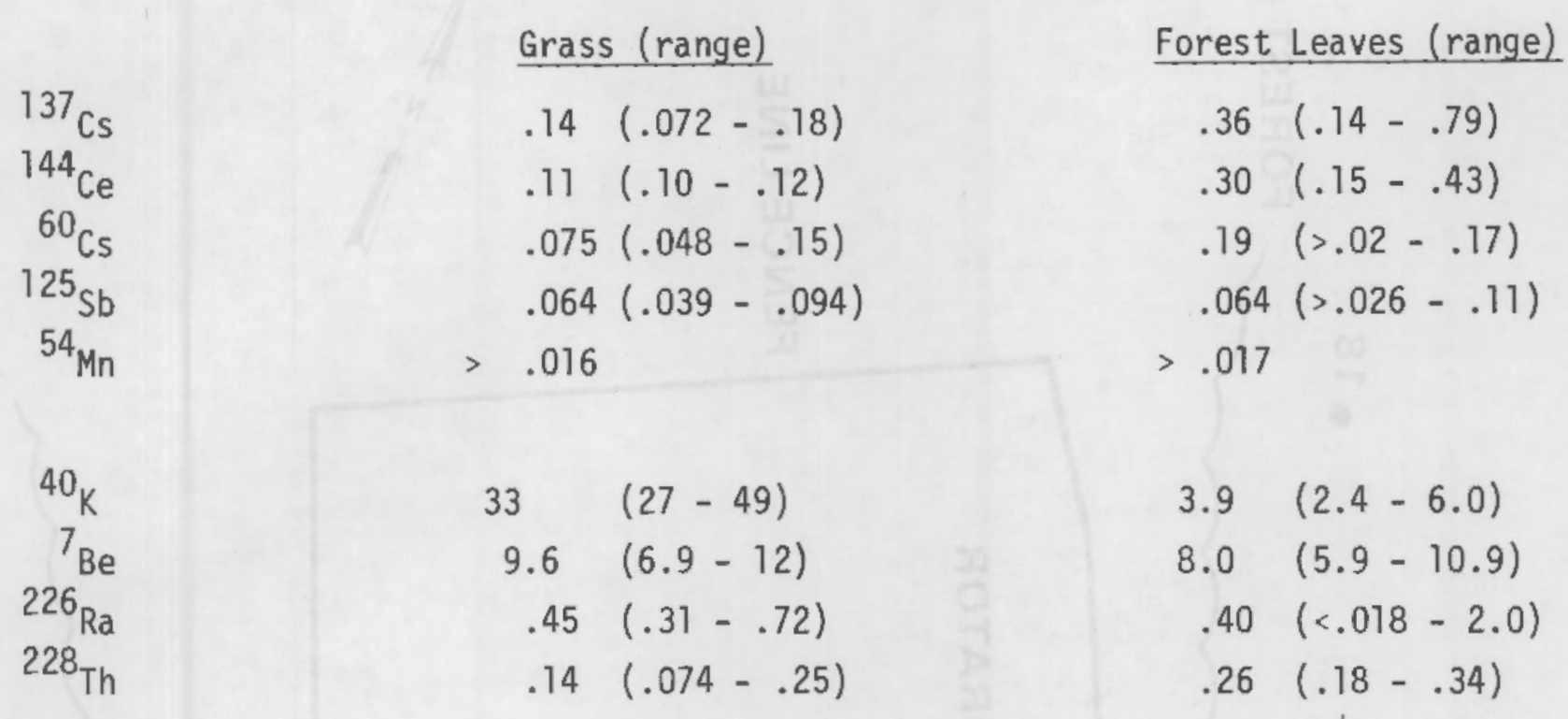




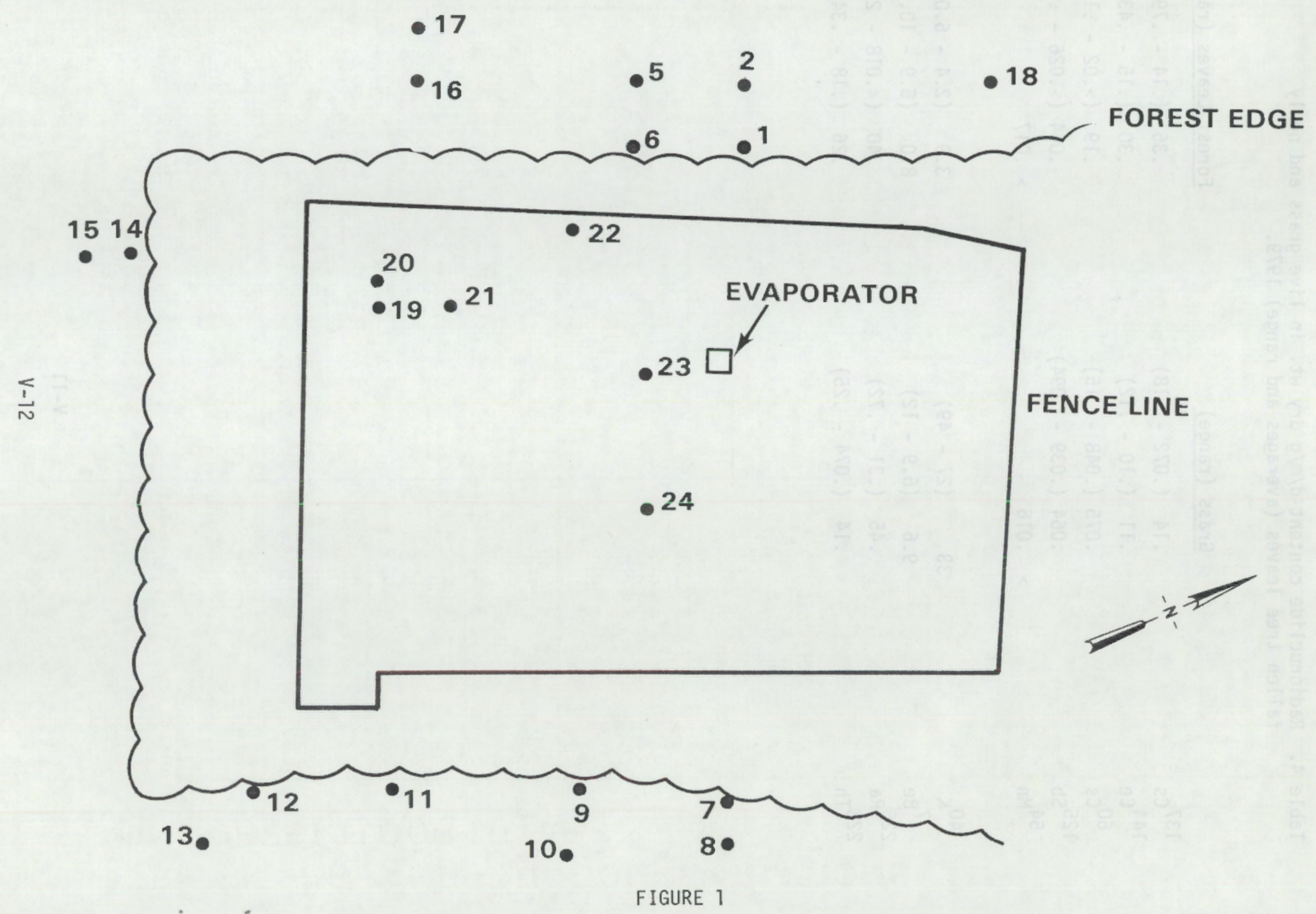


${ }^{7} \mathrm{Be},{ }^{40} \mathrm{~K},{ }^{226} \mathrm{Ra}$ AND ${ }^{228} \mathrm{Th}$ CONCENTRATIONS IN FOREST FLOOR LITTER

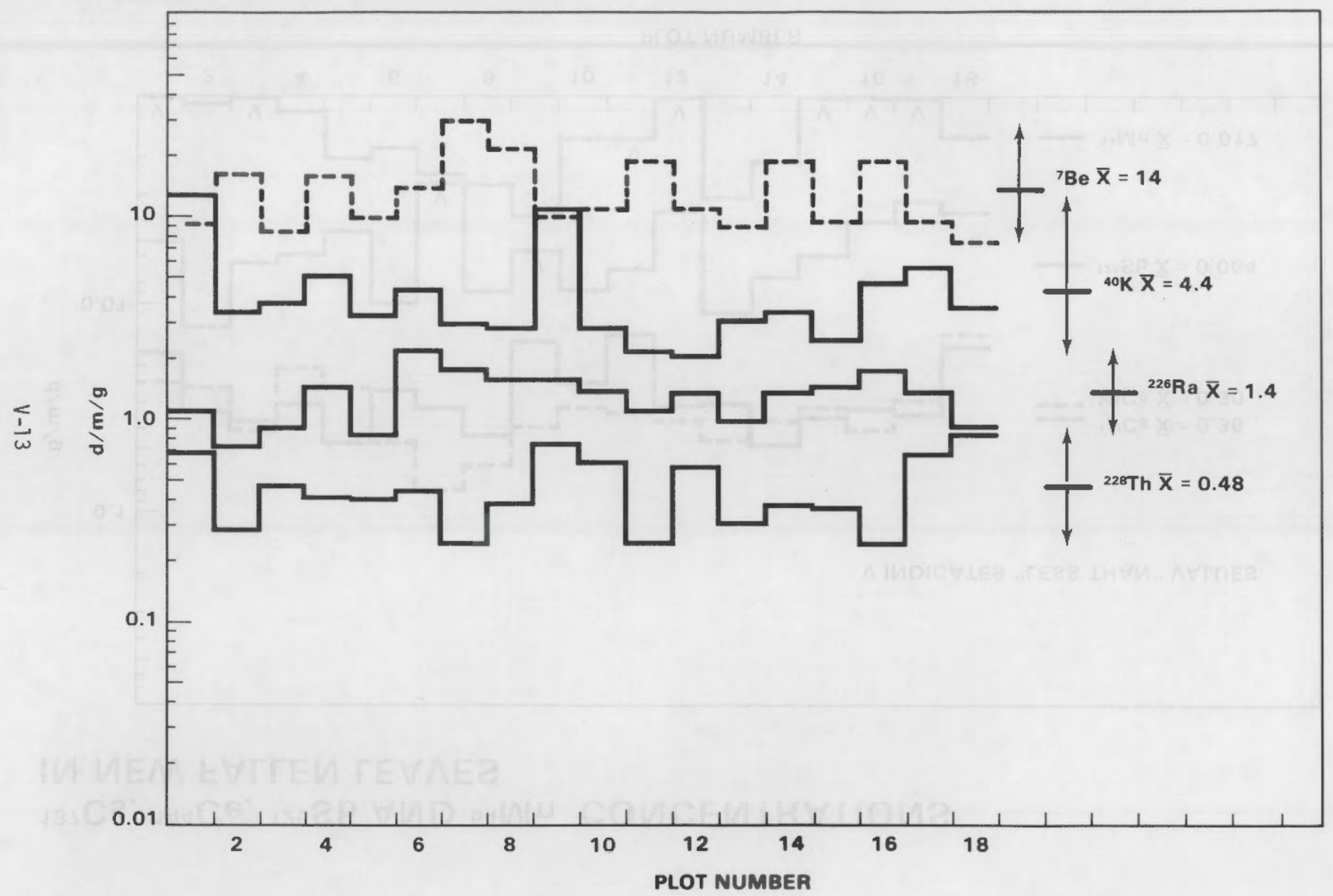

FIGURE 2 
${ }^{137} \mathrm{Cs},{ }^{144} \mathrm{Ce},{ }^{125} \mathrm{Sb}$ AND ${ }^{54} \mathrm{Mn}$ CONCENTRATIONS

IN NEW FALLEN LEAVES

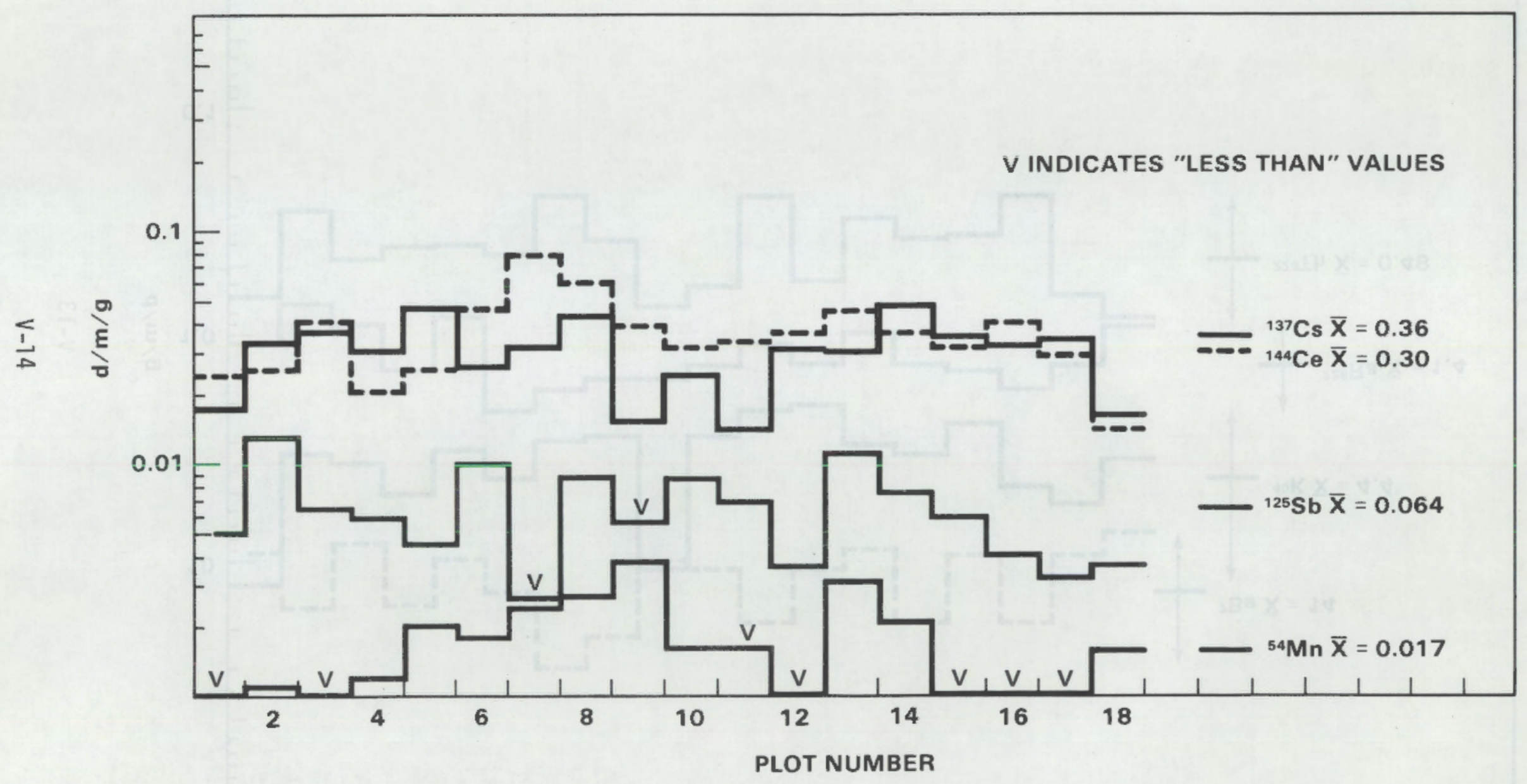

FIGURE 3 
${ }^{7} \mathrm{Be},{ }^{40} \mathrm{~K},{ }^{226} \mathrm{Ra}$ AND ${ }^{228} \mathrm{Th}$ CONCENTRATIONS IN NEW FALLEN LEAVES

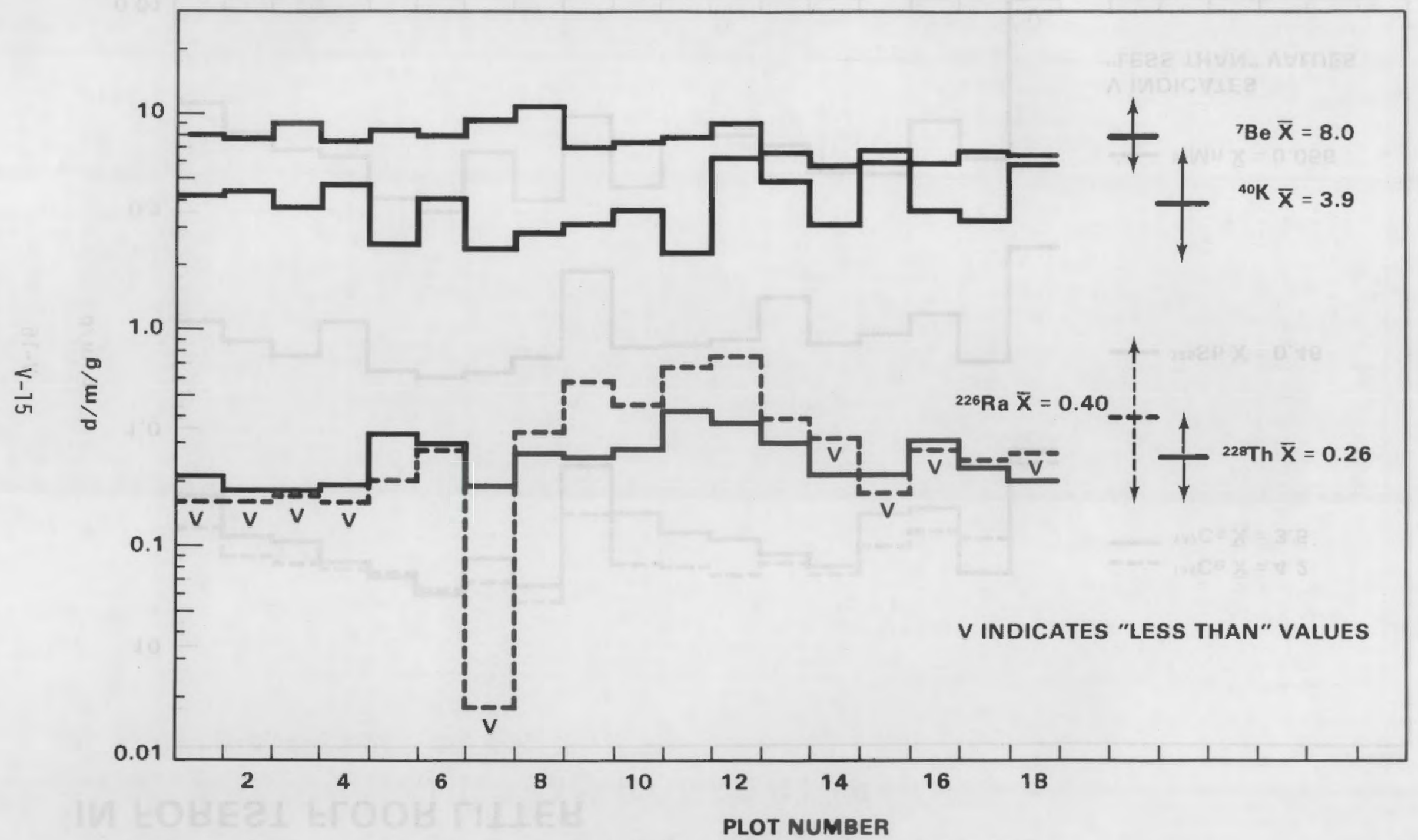

FIGURE 4 
${ }^{137} \mathrm{Cs},{ }^{144} \mathrm{Ce},{ }^{125} \mathrm{Sb}$ AND ${ }^{54} \mathrm{Mn}$ CONCENTRATIONS

IN FOREST FLOOR LITTER

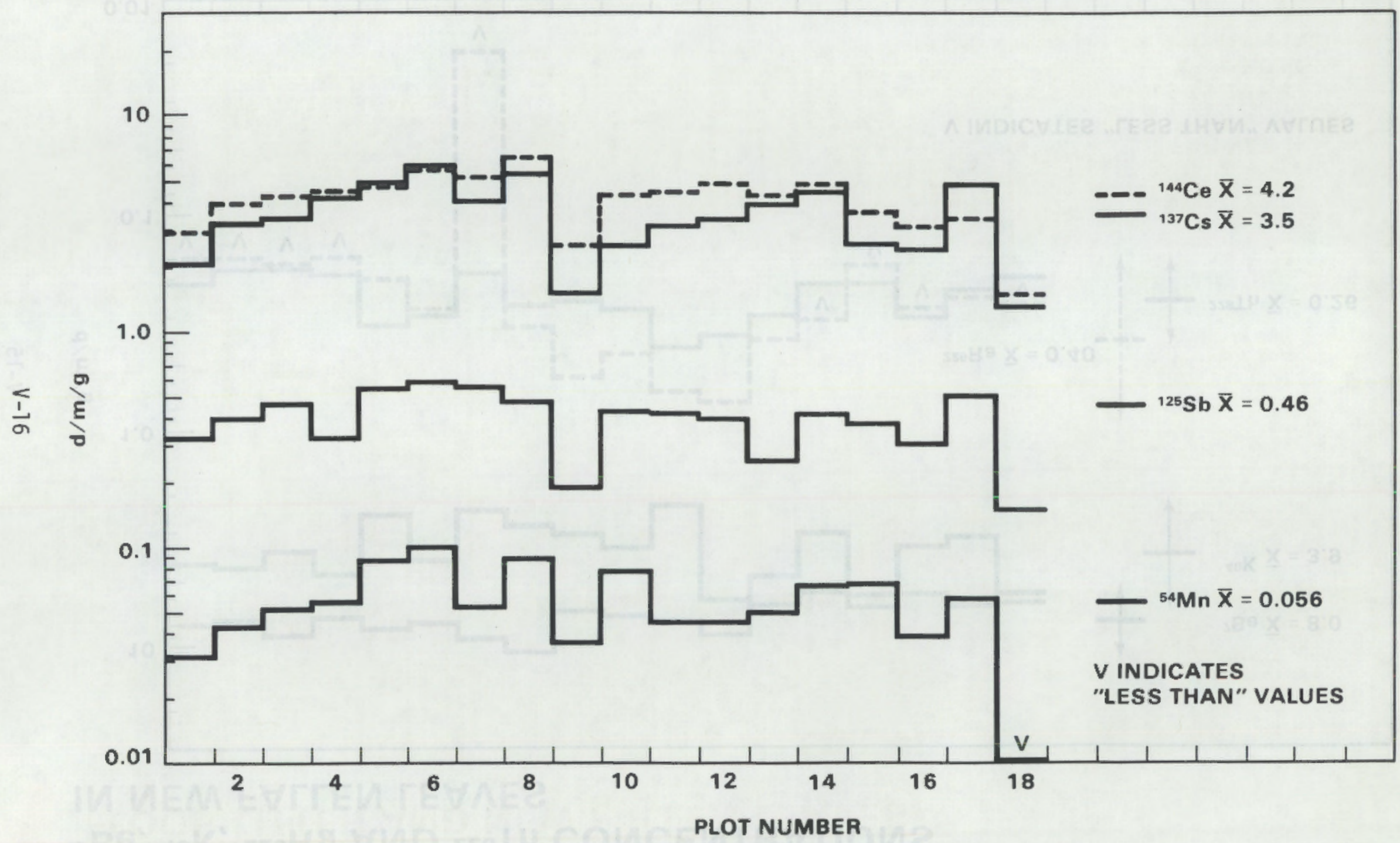

FIGURE 5 


\section{${ }^{\circ}$ CO CONCENTRATION IN FOREST}

\section{FLOOR LITTER AND NEW FALLEN LEAVES}

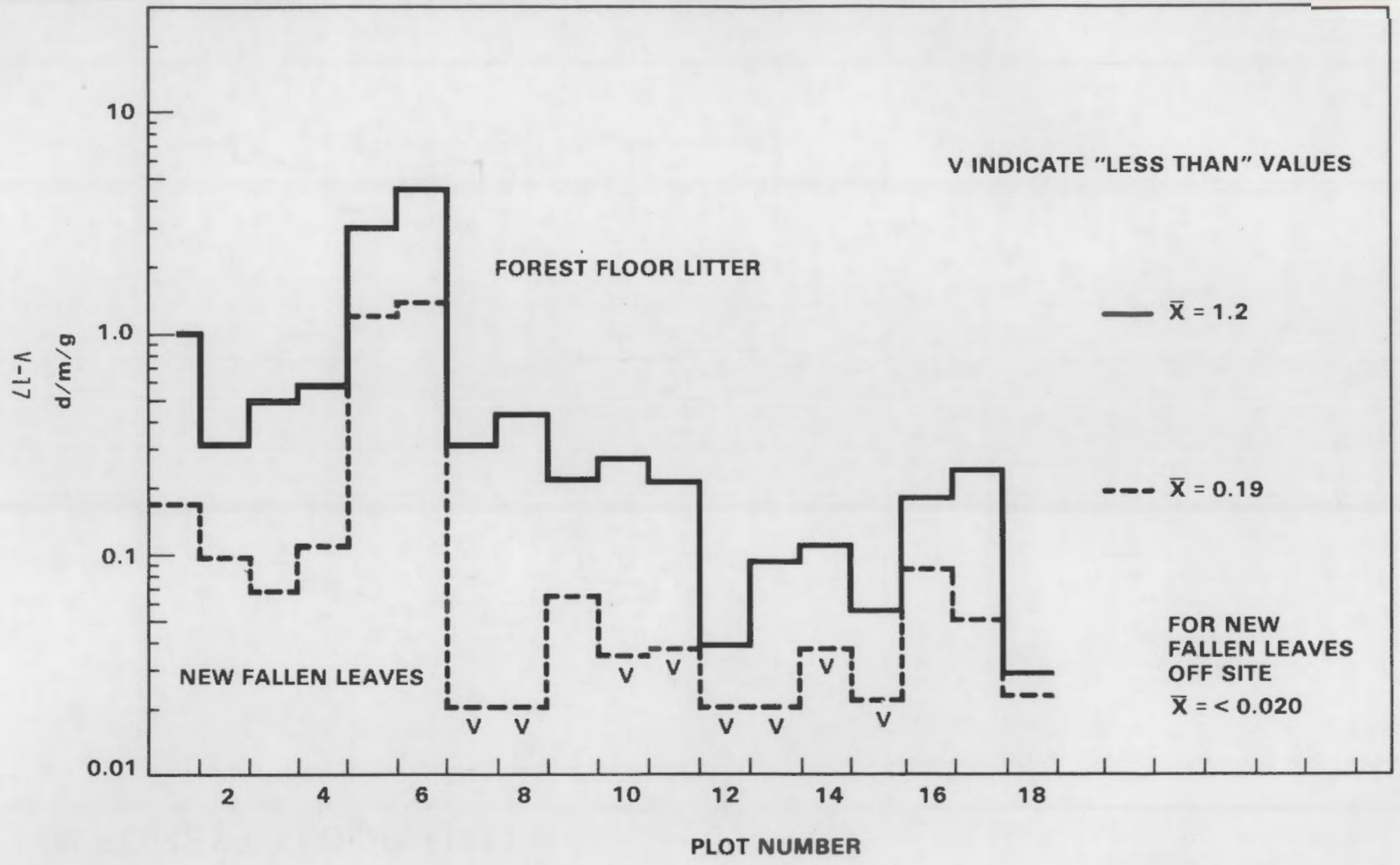

FIGURE 6 

SECTION VI

\section{MIGRATION OF WASTE RADIONUCLIDES THROUGH SOILS AT MAXEY FLATS, KY}

Los Alamos Scientific Laboratory Los Alamos, New Mexico 87545 
TITLE: MIGRATION OF WASTE RADIONUCLIDES THROUGH SOILS AT MAXEY FLATS, KY

AUTHOR(S): w.L. Polzer, LS-6

E.H. Essington, LS-6

E.B. Fowler, LS-6

SUBMITTED TO: Contribution to NRC interim report on the Maxey Flats Shallow Land Waste Burial Program

\footnotetext{
By acceptence of this article, the publisher recognizes that the U.S. Government retains nonexclusive, rovalty free license to publish or reproduce the published form of this coniribu. tion, or to sllow others to do so, for U.S. Govermment pur. poses.

The Los Alamos Scientific Laboratory requests that the pub lisher identity this articie as work performed under the aus. pices of the U.S Department of Energy
} 


\author{
Migration of Waste Radionuclides Through Soils \\ at Maxey Flats, KY \\ W.L. Polzer, E.H. Essington, and E.B. Fowler
}

\title{
Summary
}

The Los Alamos Scientific Laboratory (LASL) and the University of California, Berkeley (UCB) in a cooperative project are studying the movement of water into trenches and water and radionuclide movement out of trenches as influenced by precipitation and physical, chemical and biological characteristics of the soil and waste. The site chosen for the study is the Maxey Flats, KY shallow radioactive waste burial facility.

LASL's efforts include the evaluation of the distribution of waste radionuclides in soil near shallow waste-burial trenches with respect to seasonal changes in soil moisture movement and waste/soil interactions. That evaluation should aid the Nuclear Regulatory Commission (NRC) in 1) developing site selection criteria for future waste-burial sites and 2) evaluating the need for long-term surveillance and maintenance at existing burial sites.

Porous cups were implanted in the soil near section four of the experimental trench (T4) and near waste-burial trench 19S. Those porous cups allow the in situ sampling on a seasonal basis of soil solutions at various depths and distances from those trenches.

The distribution of ${ }^{3} \mathrm{H}$ did suggest several patterns of water movement in the soil environment. Water may move l) along a porous zone such as a landfill/soil interface, 2) from the soil surface downward and toward the burial trench near the surface and 3) down and away from the trench at depth, as influeneed by the hydrostatic head in the trench.

The distribution of radionuelides other than ${ }^{3} \mathrm{H}$ indicates interactions with soil such that migration is inhibited with respect to the movement of water. The degree of interaction differs with the different radionuelides. Cesium-137 
was not detected in any of the soil solutions. Plutonium-238 and ${ }^{60} \mathrm{Co}$ were detected at the lower depths within a distance of 3 meters (10 feet) from 19S. Additional porous cups will be implanted to a depth of about 8 meters (25 feet) in order to evaluate water and radionuclide migration in soil near the base of burial trenches. Detailed characterization of soil solutions will be made where significant concentrations of waste radionuclides exist. $\underline{\text { Introduction }}$

The field experiments at Maxey Flats were initiated in 1979. Personnel from LASL and UCB initiated a cooperative project as a part of those field studies. The effort of the two groups relates to radioactive waste/soil interactions and soil moisture movement respectively. The experimental design and status of the LASL effort will be discussed in this section.

The practice of shallow land burial of waste poses certain key questions, such as:

1. to what extent do radionuclides migrate from a burial trench,

2. what are the waste and soil characteristics that inhibit migration,

3. what characteristics of waste and soil enhance the potential for migration of the radionuclides,

4. can a knowledge of waste/soil interactions be used to predict the potential for migration and can rates of transport be inferred from those data, and

5. how can a knowledge of waste/soil interactions be applied to new waste management systems?

The objectives of the field study address the above questions. Further, results obtained in laboratory investigations will be compared to those obtained in the field to determine the applicability of the former to field investigations. Methods and procedures developed in the laboratory for the investigation of waste/soil interactions have been modified for field application. (1) 


\section{Experimental Approach}

Porous cups were implanted in the north wall of section four of the experimental trench (T4) prior to the backfilling and capping of that trench (Fig. 1). Samples of soil solution are drawn into the porous cups under either saturated or unsaturated soil conditions and later obtained at the surface by vacuum. The soil solutions are analyzed for physical and chemical characteristics and for radionuclide content. The radionuclides of interest include ${ }^{3} \mathrm{H},{ }^{238} \mathrm{Pu},{ }^{233}, 234 \mathrm{U}$, ${ }^{238} \mathrm{v},{ }^{137} \mathrm{Cs}$, and ${ }^{60} \mathrm{Co}$.

In the initial array at $\mathrm{T} 4$, a number of porous cups were implanted at each of two locations in the exposed trench wall at horizontal depths of about $1 / 2$ to 1 meter (18 to 36 inches); an additional three cups were implanted associated with the trench cap at each location. Samples of soil were obtained as holes were bored to receive the porous cups; in addition, soil samples from the exposed trench wall were obtained which represent a profile from about a 3 meter (10-foot) depth to about 7 meters (23 feet) deep.

At trench 19S (19S) an array of 11 holes was instrumented with a total of 27 porous cups (Fig. 2). Samples of soil representing successive 1-meter (3-foot) increments were obtained. At both trenches, porous cups were back packed with soil; that soil represented the original removed at each respective depth.

Samples of soil solution were obtained from the porous cups in November, December, February, and May. Cold weather in November permitted the collection of only ll samples; the May samples have not been received for analyses. Soils and soil solutions were analyzed in the laboratory at LASL for the radionuclides listed above.

\section{Results and Discussion}

\section{$\underline{T 4}$}

Results of ${ }^{3} \mathrm{H}$ analyses for the sampling locations at $\mathrm{T} 4$ (Table I) 


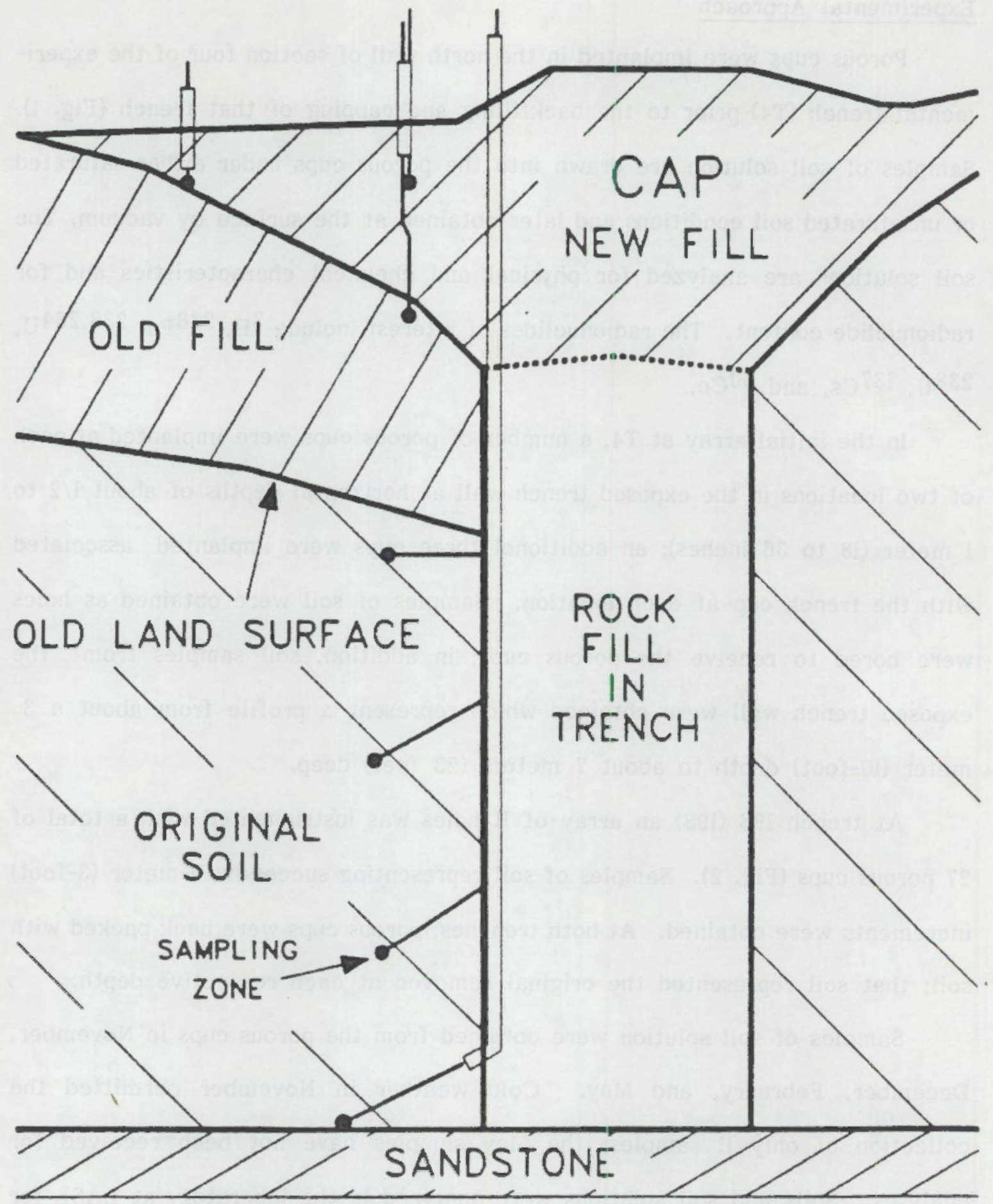

Fig. 1. Schematic Diagram of Porous Cup Sampling Locations Near T4. 


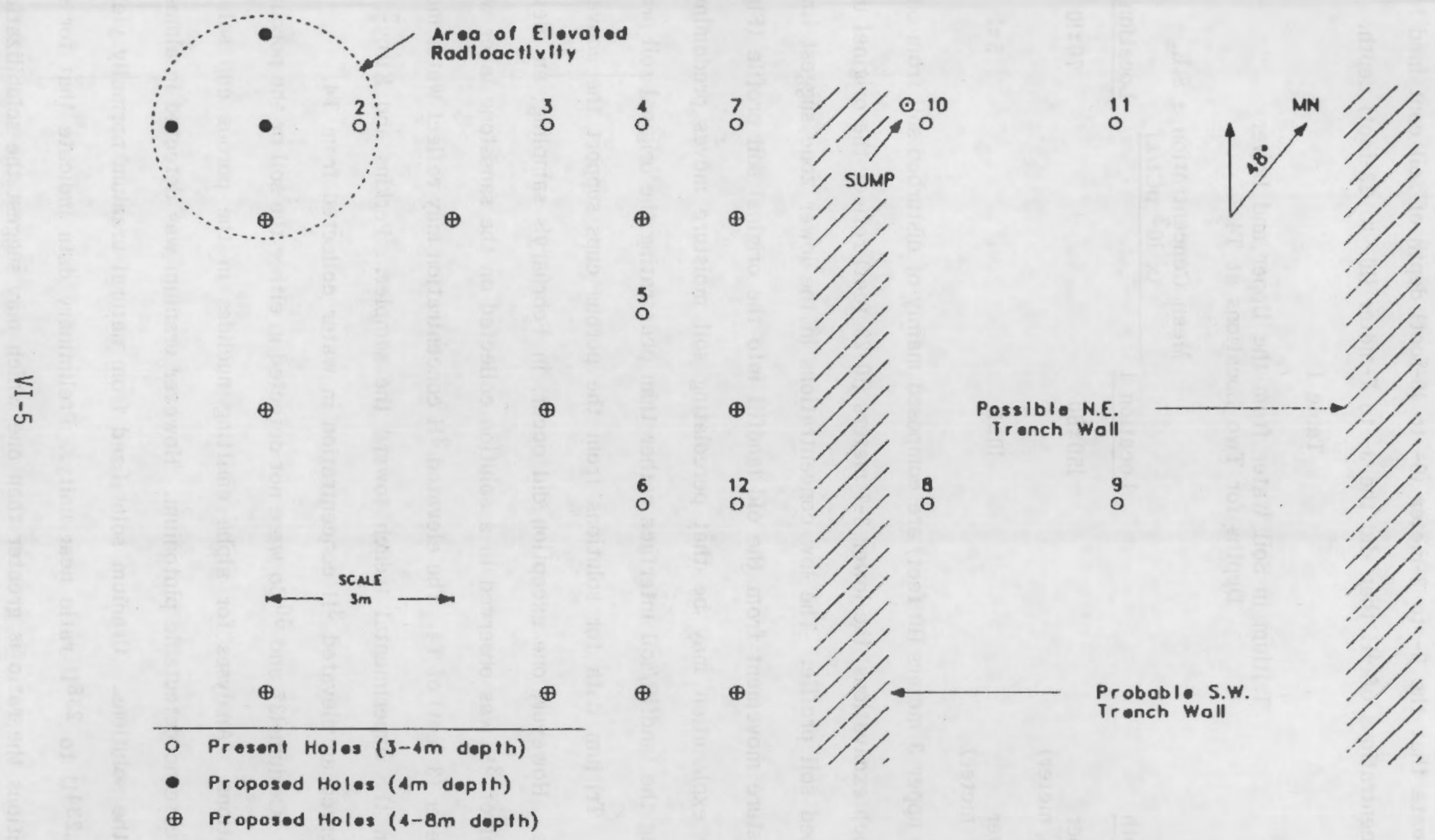

Fig. 2. Plan View of Present anò Proposed Locations of Porous Cup Samplers Near Trench 19S. 
indicate that the 0 - to 3 -meter (0- to 10 -foot) depth of soil contained higher concentrations of ${ }^{3} \mathrm{H}$ than did the 3 - to 7 -meter $(10-$ to 23 -foot) depth.

Table I

Tritium in Soil Water from the Upper and Lower Depths for Two Locations at T4

Depth

Upper

(0-3 meter)

Lower

(3-7 meter)
Mean Concentration \pm S.E. (x $\left.10^{3} \mathrm{pCi} / \mathrm{l}\right)$

Location $1-\frac{\left(\mathrm{x} 10^{3} \mathrm{pCi} / \mathrm{l}\right)}{\text { Location } 2}$

$150 \pm 60$

$70 \pm 10$

$10 \pm 5$

$5 \pm 1$

The upper 3 meters (10 feet) are composed mainly of disturbed soil from on-site trench excavations, the lower 3-7 meters (10-23 feet) reflect the original undisturbed soil profile. The low concentrations in the lower zone suggest limited moisture movement from the old landfill into the original soil profile (Fig. 1). One explanation may be that percolating soil moisture moves predominately along the landfill/soil interface rather than penetrating the original soil profile.

Tritium data for solutions from the porous cups support the above soil data. However, one exception did occur; in February's sampling, an elevated level of ${ }^{3} \mathrm{H}$ was observed in a solution collected on the sandstone layer within 1 meter ( 3 feet) of $\mathrm{T} 4$. The elevated ${ }^{3} \mathrm{H}$ concentration may reflect water moving from the experimental trench toward the sampler. Perkins and Kirby ${ }^{2}$ have observed an elevated ${ }^{3} \mathrm{H}$ concentration in water collected from $\mathrm{T} 4$.

Cesium-137 and ${ }^{60}$ Co were not detected in either the soil or the porous cup solutions. Analyses for alpha emitting nuclides in the porous cup solutions indicate no detectable plutonium. However uranium was detected in almost all of the solutions. Uranium solubilized from natural uranium normally yields a $233,234 \mathrm{U}$ to ${ }^{238} \mathrm{U}$ ratio near unity. Preliminary data indicate that for some solutions the ratio is greater than one which may suggest the solubilization of 
$233,234 \mathrm{U}$ from a non-natural source, i.e., buried waste. Uranium concentrations and the ratio of $233,234 \mathrm{U}$ to $238 \mathrm{U}$ will continue to be monitored for the development of trends.

The solutions collected by a porous cup at approximately 1.5 meters (5 feet) above the sandstone layer were different from those collected above or below; the solution turned dark brown in color. Tentative identification of heavy metals indicated significant quantities of stable iron and cobalt. Porous cup solutions from nearby soil were clear and significant quantities of stable iron and cobalt were not observed. The composition of heavy metals in the solution obtained from the one porous cup suggests that that particular soil solution is moving through a unique source. The solution from that porous cup will continue to be monitored closely for its unusual characteristics.

In summary, one explanation of the ${ }^{3} \mathrm{H}$ data is that water penetrating the soil surface percolates to an old landfill. Upon reaching the interface between the old landfill and the original soil, the water moves along that interface; only a limited amount penetrates the original soil profile. Cesium-137, $60 \mathrm{Co}$ and ${ }^{238} \mathrm{Pu}$ were not detected in any of the porous cup solutions. Uranium was detected in nearly all of the solutions; a major portion was probably solubilized from natural uranium. However, some uranium may have been solubilized from waste.

$\underline{19 S}$

The distribution of ${ }^{3} \mathrm{H}$ in soil as a function of distance from the trench at various depths from the surface is given in Figure 3 . The ${ }^{3} \mathrm{H}$ eoncentration in soil water was determined on an aliquot of soil taken from the bore sample 1 meter ( 3 feet) in length and 7.6 centimeters ( 3 inches) in diameter. In the case of soil samples several trends are indicated; results from porous cup samples support those trends. Concentration decreased to a minimum, then increased at 


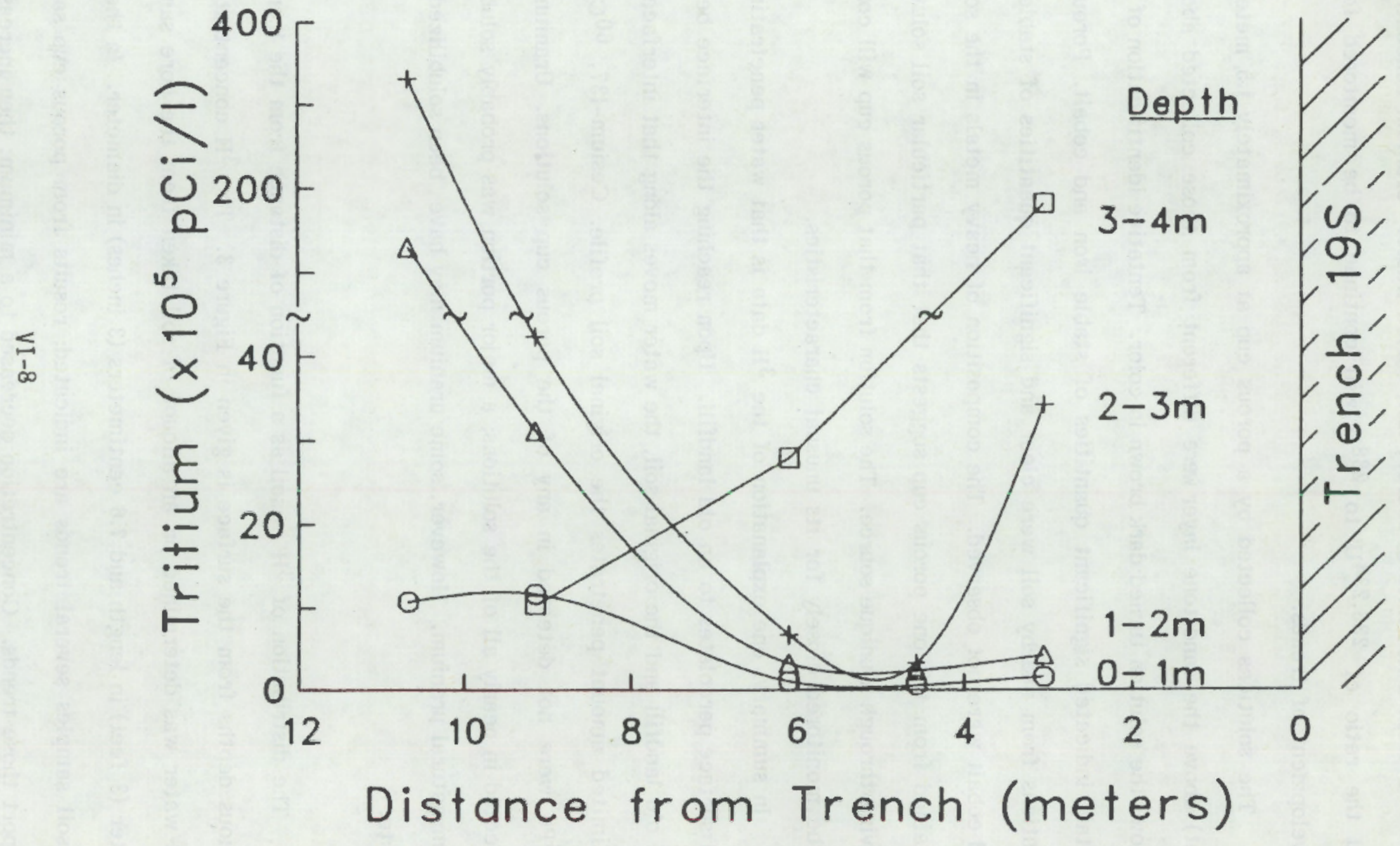

Fig. 3. The Distribution of ${ }^{3} \mathrm{H}$ in Soil as a Function of Distanec from Trench $19 \mathrm{~S}$ at Various Depths from the Surface. 
greater distances from the trench. In addition to the lateral change, a vertical change was observed; ${ }^{3} \mathrm{H}$ increased with depth.

Tritium, as tritiated water, moves as the water moves; thus ${ }^{3} \mathrm{H}$ may in certain cases be used as a tracer for the movement of water. The above trends suggest that water moves away from the trench and downward. At a distance of about 11 meters (35 feet) from the trench an apparent second source of tritiated water appears to be moving from the near surfece down and towards the trench. The minimum in the curves indicates that the waters from the two sources have intermixed at a distance of approximately 5 meters (15 feet) from the trench.

The low ${ }^{3} \mathrm{H}$ concentrations near the trench for the 0 - to $1-$ meter $(0-$ to 3- foot) depth curves suggest little influence of trench water at those depths. That conclusion is supported by the fact that the water level in the trench is between 2 and 3 meters ( 6 and 10 feet) below the soil surface. The slightly elevated ${ }^{3} \mathrm{H}$ concentrations at the $1-$ to 3 -meter (3- to 6 -foot) depth may reflect an upward movement of water from below. Schulz ${ }^{3}$ in his work on soil moisture potentials suggests that significant removal of soil moisture could occur by evapotranspiration; soil moisture movement mechanisms would tend to replace that moisture.

Data are insufficient to allow the assessment of water movement at the 3 - to 4 -meter $(10$ - to $13-f o o t)$ depth with the same degree of certainity as that at the 0 - to 3 -meter $(0$ - to 10 -foot) depths. However the data do suggest that the potential for movement of water away from the trench is much greater at the 3- to 4-meter (10- to 13-foot) depth and that the influence of water moving down from the surface is much less at the greater depths. The increase in hydrostatic head of the water in the trench at the greater depths could account for the increased movement of water away from the trench.

The initial data for the distribution of radionuclides other than ${ }^{3} \mathrm{H}$ near 
19S indicate that those radionuclides do interact with the soil thus minifying their movement. Soil analyses for gamma emitting radionuclides indicate that the second source of high ${ }^{3} \mathrm{H}$ concentration also contains ${ }^{60} \mathrm{Co}$ and ${ }^{137} \mathrm{Cs}$. Gamma analyses on porous cup solutions indicate the presence of ${ }^{60} \mathrm{Co}$ in soil water taken from near the second source and the absence of ${ }^{60} \mathrm{Co}$ in soil water at greater distances from that source. A similar distribution was observed near $19 \mathrm{~S}$ in that ${ }^{60} \mathrm{Co}$ was detected in soil water collected nearest the trench and at depths of 3-4 meters (10-13 feet). Cesium-137 was not detected in any of the soil water samples which is indicative of its characteristic to be strongly sorbed by soils.

Plutonium data indicate results similar to those obtained for ${ }^{60} \mathrm{Co}$, i.e., the presence of ${ }^{238} \mathrm{Pu}$ in soil water near $19 \mathrm{~S}$ at the lower depths and its absence further away from the trench and near the surface.

Uranium-233, 234 and ${ }^{238} \mathrm{U}$ were detected in essentially all water samples. Those results are due, in part, to the natural occurrence of ${ }^{234} \mathrm{U}$ and ${ }^{238} \mathrm{U}$. However preliminary data do suggest differences in concentrations among samples and also differences in the ratio of ${ }^{233,234} \mathrm{U}$ to ${ }^{238} \mathrm{U}$. A ratio of near unity would be expected for natural uranium; a ratio of greater than one may be indicative of waste uranium. Additional data are needed before any definite conclusions can be drawn.

The relative distribution of radionuclides observed in the soil solutions in general support the recent laboratory results obtained by Weiss and Czyscinski ${ }^{4}$ using an unweathered shale from the disposal site and liquid waste from trench 27.

In summary the distribution of ${ }^{3} \mathrm{H}$ in the vicinity of $19 \mathrm{~S}$ suggests a net movement of water toward the trench near the surface from the surrounding soil and a net movement of water away from the trench and downward, particularly

- at the lower depths. Movement of other radionuclides was observed but to a lesser degree that for ${ }^{3} \mathrm{H}$, probably due to their interaction with the soil. 


\section{Future Plans}

Additional porous cups will be implanted in holes to be drilled to the lower sandstone marker bed, about 8 meters (25 feet), at the 19S site (Fig. 2) and at the T4 site. A more nearly complete determination of the influence of the associated trench face can thus be made.

Field analyses will be conducted for $\mathrm{pH}, \mathrm{Eh}$, conductivity, alkalinity, and net charge associated with the radionuclides of in situ soil solutions.

The chemical and radiochemical data obtained by LASL will be correlated with soil moisture data obtained by UCB to provide patterns of water flow into trenches and water flow and radionuclide migration out of trenches.

There are active plans by the Commonwealth of Kentucky to cover a part of the Maxey Flats reservation with material that will be impervious to water. Data obtained relative to transport from the trench reflecting "before cover" and "after cover" will provide important guidance for future waste management. Reference

lFowler, E.B., E.H. Essington, and W.L. Polzer, "Interactions of Radioactive Wastes with soil - A review," Nuclear Regulatory Commission report NUREG/ CR-1155 (1979).

${ }^{2}$ Perkins, R.W. and L.J. Kirby, Maxey Flats Research Meeting. Lexington, KY (April 22-23, 1980).

${ }^{3}$ Schulz, R.K., Private Communication (1980).

${ }^{4}$ Weiss, Allen J. and Czyscinski, Kenneth S. This report. 



\section{SECTION VII}

STUDY OF UNSATURATED ZONE HYDROLOGY

University of California

Berkeley, California 
STUDY OF UNSATURATED ZONE HYDROLOGY

\author{
R. K. Schu 12 \\ University of California \\ Berkeley, California
}

\begin{abstract}
SUMMARY
A problem of serious concern at Maxey Flats is the intrusion of water into the waste burial trenches and the exit of this water from the trenches along with radionuclides. The pathways of water entry through trench caps, or through the soil profile in the rows between the trenches, are being investigated in this study. Once the more important modes of water entry are identified, appropriate countermeasures such as trench cap redesign, modification of vegetative cover, etc., can be formulated. The study is being carried out by implantation of soil moisture sensors at various depths in the trench caps and in the soil profiles adjacent to the trenches to enable determination of soil moisture gradients. Mini-porous cups have been installed in a paired fashion with the moisture cells to allow extraction of soil solution samples. The samples are analyzed for ${ }^{3} H$, a useful hydrologic tracer due to the high ${ }^{3} \mathrm{H}$ concentration in the trenches. Pentafluorobenzoic acid has been sprayed on the soil surface and is also used as a hydrologic tracer. To date it has been found that the cap on trench 195 is quite permeable to water. Rainwater readily passed through the cap into the trench during the past winter. This was evidenced by both soil moisture measurements and the pentafluorobenzoic acid tracer. A decreasing concentration gradient of $3 \mathrm{H}$ from the trench water source upwards through the trench cap to the soil surface indicates water movement upwards to the surface during dry periods. An instrumented stack in the soil profile $10 \mathrm{~m}$ (30 ft) away from the side of the trench indicated that water was not entering trench 195 via percolation into the soil profile at this point and then lateral movement of water into the trench. Hydrogen-3 data obtained on this stack also indicated that trench water was not migrating outward from the trench to this location. Work on the experimental trench, section T4, indicated that the cap on this new trench prevented water from entering the trench by percolation through the cap during the winter of 1979-1980. However, this does not indicate that the cap will not become more permeable with the passage of time.
\end{abstract}


Continuing work will encompass instrumentation of the soil profiles to deeper depths to enable a study of the hydrology to about the depth of the bottom of waste burial trenches.

\section{INTRODUCTION}

The primary goal of this study is to determine the pathway(s) of water entry into the waste burial trenches; that is, is the water principally entering the trenches through the caps or is the water percolating downward through the soil profile and entering through the walls? Determination of entry pathways will enable planning of appropriate countermeasures that could be taken to reduce the water entry. These countermeasures might include trench cap redesign, efforts to increase water runoff from the entire burial site, a different cropping regime to increase evapotranspiration, etc.

\section{EXPERIMENTAL APPROACH}

A transect across trench 195 and the adjacent area was instrumented as shown in Fig. 1. Two types of instrumentation were installed in the soil profile: (1) soil moisture cells (Soiltest Co.), and (2) mini-porous cups. The soil moisture cells were installed to allow measurement of soil water suction (soil moisture tension) gradients. The mini-porous cups were implanted very close $(5 \mathrm{~cm})$ to the soil moisture cells to allow extraction of soil water in the region of the soil moisture cells. Mini-porous cups were used instead of full-sized cups so as not to influence subsequent measurements made with the soil moisture cells. The mini-cups have a volume of approximately $2 \mathrm{ml}$ and the soil solution samples are taken after the soil moisture cell readings. The soil moisture cells are then not read aga in until a two-week period has passed. The porous cups allow extraction of soil water suction (tension); therefore, they can be used for sampling saturated or moist unsaturated soils.

It was originally intended to instrument the transect to a depth of $7 \mathrm{~m}$ $(22 \mathrm{ft}$ ) into the soil profile. However, it was not possible to bore holes to this depth with the drilling equipment available at the time the transect was set up. Frequently rock was encountered forcing abandonment of even shallow holes. The mini-porous cups and the soil moisture cells were 
installed side by side in the holes as depicted in Fig. 1. Electrical leads from each of the moisture sensors and fine tubing (bore $=1 \mathrm{~mm}$ ) from the mini-porous cups terminated in an instrument box mounted above the soil surface and to one side of the instrument stack or "station" located vertically in the soil profile.

After the instrumentation was installed and the holes refilled with the soil removed from the holes, a tracer was sprayed on a swath $3 \mathrm{~m}(10 \mathrm{ft})$ wide by $23 \mathrm{~m}$ (75 ft) long with the swath being centered over the instrument stations. The tracer consisted of $250 \mathrm{~g}$ of pentafluorobenzoic acid dissoived in 8 liters of water. The purpose of the tracer was to augment information on movement of the soil water. In a cooperative effort, Dr. Glenn Thompson of the University of Arizona furnished the tracer and performed the analyses of the soil solutions for benzoic acid content.

The experimental trench, section T4, was instrumented in a similar fashion (Fig. 2) with the exception that it was not possible to bore holes in the area away from the trench due to rocks. Pentafluorobenzoic acid tracer was also sprayed on the surface of this trench cap. Both trench instrumentations were completed 0ctober $26,1979$.

\section{RESULTS AND DISCUSSION}

The first soil moisture cell measurements were taken on October $30,1979$. The measurements were taken at approximately two-week intervals thereafter and are continuing at this time. The moisture profile graphs shown in Fig. 3 were constructed from data taken at selected dates at station no. 1, trench 19S. These moisture profiles show that the soil was quite dry when the first readings were made on October 30,1979 . As the fall and winter progressed, the profile became wet down to $396 \mathrm{~cm}(13 \mathrm{ft})$ by February 21,1980 . The profile remained generally unsaturated, though quite wet, during the entire winter period. Since the trench $30 \mathrm{ft}$ away had a free water table at about $244 \mathrm{~cm}(8 \mathrm{ft})$ depth below the surface, it is evident that soil water from the area of station 1 was not moving to the trench.

On January 15, 1980, the mini-porous cups implanted in the soil profile were first used to extract soil solution for ${ }^{3} \mathrm{H}$ and pentafluorobenzoic acid 
tracer analyses. The ${ }^{3} \mathrm{H}$ results for trench 195 , station 1 , are given in Table 1. The concentration of ${ }^{3} \mathrm{H}$ in the soil solution was essentially constant with depth at a concentration of about $10^{4} \mathrm{pCi} / \ell$ and this would tend to indicate that the source of the ${ }^{3} \mathrm{H}$ was not the trench. Apparently, water is neither moving to the trench during wet periods from the area of station 1 , nor moving from the water-logged trench to the area of station 1 during relatively dry periods.

Data obtained from stations 4 and 5 , trench 19S, in the trench cap showed a different pattern from that of station 1 . When the first moisture cel1 measurements were made on 0ctober 30, 1979, the cap was moist at the surface with soil moisture increasing with depth until saturation was obtained at $244 \mathrm{~cm}(8 \mathrm{ft})$. During the course of the winter, the entire cap became progressively wetter so that by the end of March, 1980, the cap was saturated nearly to the surface. This would tend to indicate substantial water movement through the cap into the burial trench. The ${ }^{3} \mathrm{H}$ content of the soil solution in the cap profile is given in Tables 2 and 3 . The ${ }^{3} H$ content at both stations and at two sampling times evidence a substantial gradient of ${ }^{3} \mathrm{H}$ from the trench through the cap to the soil surface. This indicates water $\left({ }^{3} \mathrm{H}_{2} \mathrm{D}\right)$ movement from the trench upward through the cap to the surface during dry periods. Table 4 shows the distribution of pentafluorobenzoic acid tracer in the trench cap on January 15, 1980. This tracer was sprayed on the soil surface on October 26, 1979, and the tracer movement corroborates with the soil moisture cell findings discussed above. All in all, it is apparent that the trench cap is quite permeable, with water moving either upwards or downwards depending on weather conditions.

Not as much data have been obtained on the experimental trench, section T4, to date, as has been obtained on 19S. However, some information is available at the time of this writing. Soil moisture cell readings vs. depth into the trench cap of the experimental trench, section T4, are given in Fig. 4. This station was in the center of the cap. Here, the water slowly percolated down into the cap but much more slowly than in the cap of 19S. By May 7, 1980, the cap was only moistened down to a depth of $152 \mathrm{~cm}$ (5 ft), hence no water had yet penetrated the cap and entered the trench by this pathway. This was confirmed by tracer analysis of water taken from the 
bottom of the trench from a sump. There was no detectable pentafluorobenzoic acid present in this water. The cap on this experimental trench would appear to be more effective than that on 195 in preventing water entry, but it must be kept in mind that this is a new cap whereas the one on 195 is an aged cap. Perhaps the cap on the experimental trench, section T4, simulates the original caps placed on the waste burial trenches.

\section{FURTHER WORK}

The greatest disappointment in installing the instrument array in the trench caps and soil profiles in areas adjacent to the trenches was the inability to obtain the necessary hole depths. The possibility of using different hole drilling equipment this summer which would enable drilling to about $7 \mathrm{~m}$ ( $23 \mathrm{ft})$, even though rock would be encountered, is being explored. The stations would then be instrumented to this depth and this should yield a more comprehensive picture on the hydrology of this zone. 
Table $1-{ }^{3} \mathrm{H}$ concentration in soil solution, station no. 1, adjacent to trench 195 . Sampled 1/15/80.

\begin{tabular}{|c|c|}
\hline $\begin{array}{c}\text { Soil } \\
\text { depth, } \\
\text { ft }\end{array}$ & ${ }^{3} \mathrm{H}$ \\
\hline & $\mathrm{pCi} / \ell$ \\
\hline$\frac{1}{1 / 2}$ & $0.09 \times 10^{6}$ \\
\hline 1 & 0.08 \\
\hline 2 & 0.09 \\
\hline 3 & 0.08 \\
\hline 5 & 0.11 \\
\hline 7 & 0.11 \\
\hline 11 & 0.08 \\
\hline
\end{tabular}

Table $3-{ }^{3} \mathrm{H}$ concentration in soil solution, station no. 5 , trench 19S.

$$
3_{\mathrm{H}}
$$

\begin{tabular}{|c|c|c|}
\hline \multirow{3}{*}{$\begin{array}{c}\text { Soil } \\
\text { depth, } \\
\text { ft }\end{array}$} & \multicolumn{2}{|c|}{$3_{H}$} \\
\hline & \multicolumn{2}{|c|}{ Sampling date } \\
\hline & $1 / 15 / 80$ & $2 / 22 / 80$ \\
\hline & $\longrightarrow$ & $\ldots$ \\
\hline$\frac{1}{2}$ & $0.15 \times 10^{6}$ & $0.18 \times 10$ \\
\hline 1 & 0.18 & 0.17 \\
\hline 3 & 0.51 & 0.28 \\
\hline 4 & 2.15 & 1.70 \\
\hline 7 & 40.81 & 12.75 \\
\hline 8 & 12.88 & -- \\
\hline
\end{tabular}

Table $2-{ }^{3} \mathrm{H}$ concentration in soil solution, station no. 4, trench 195 .

\begin{tabular}{|c|c|c|c|}
\hline \multirow{3}{*}{$\begin{array}{c}\text { Soil } \\
\text { depth, } \\
\text { ft }\end{array}$} & \multicolumn{3}{|c|}{${ }^{3} \mathrm{H}$} \\
\hline & \multicolumn{3}{|c|}{ Sampling date } \\
\hline & $1 / 15 / 80$ & \multicolumn{2}{|c|}{$2 / 22 / 80$} \\
\hline & \multicolumn{3}{|c|}{$\longrightarrow \mathrm{PCi} / \ell$} \\
\hline$\frac{3}{2}$ & $0.54 \times 10^{6}$ & 0.28 & $10^{6}$ \\
\hline 1 & 1.06 & 0.65 & $"$ \\
\hline 5 & -- & 1.07 & $"$ \\
\hline 7 & 1.12 & 2.07 & $"$ \\
\hline 8 & 15.41 & 7.93 & $"$ \\
\hline
\end{tabular}

Table 4 - Pentafluorobenzoic acid tracer concentration in soil solution, station no. 5 , trench 195 .

\begin{tabular}{cc}
$\begin{array}{c}\text { Soil } \\
\text { depth, } \\
\mathrm{ft}\end{array}$ & $\begin{array}{c}\text { Pentafluoro- } \\
\text { benzoic acid }\end{array}$ \\
\hline & ppm \\
$\frac{1}{2}$ & 14 \\
1 & 17 \\
3 & 67 \\
4 & 30 \\
7 & 161 \\
8 & 175 \\
\hline
\end{tabular}


TRENCH 195

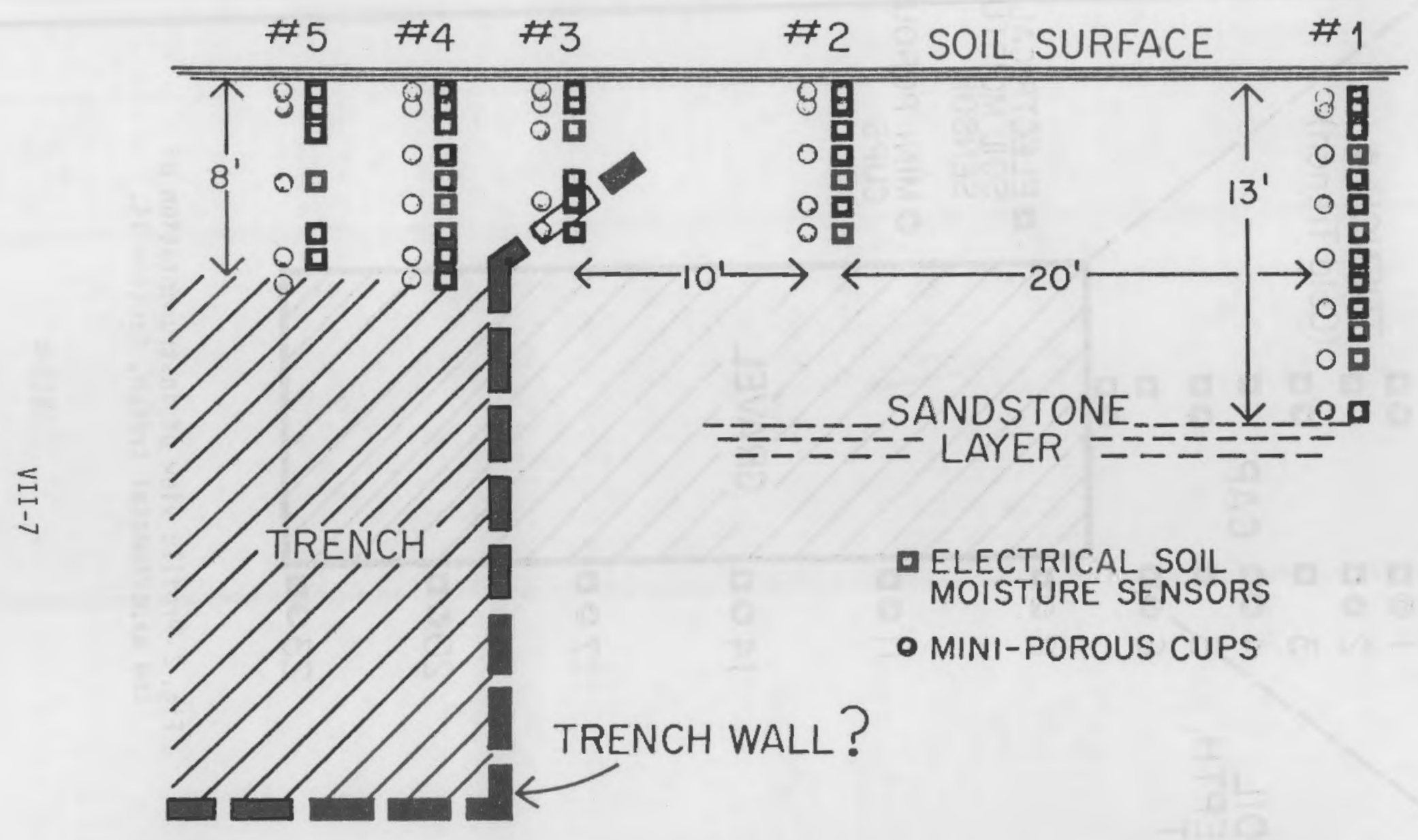

Fig. 1-Profile view of instrumented transect across trench 19S and adjacent soil. 


\section{SOIL SURFACE}

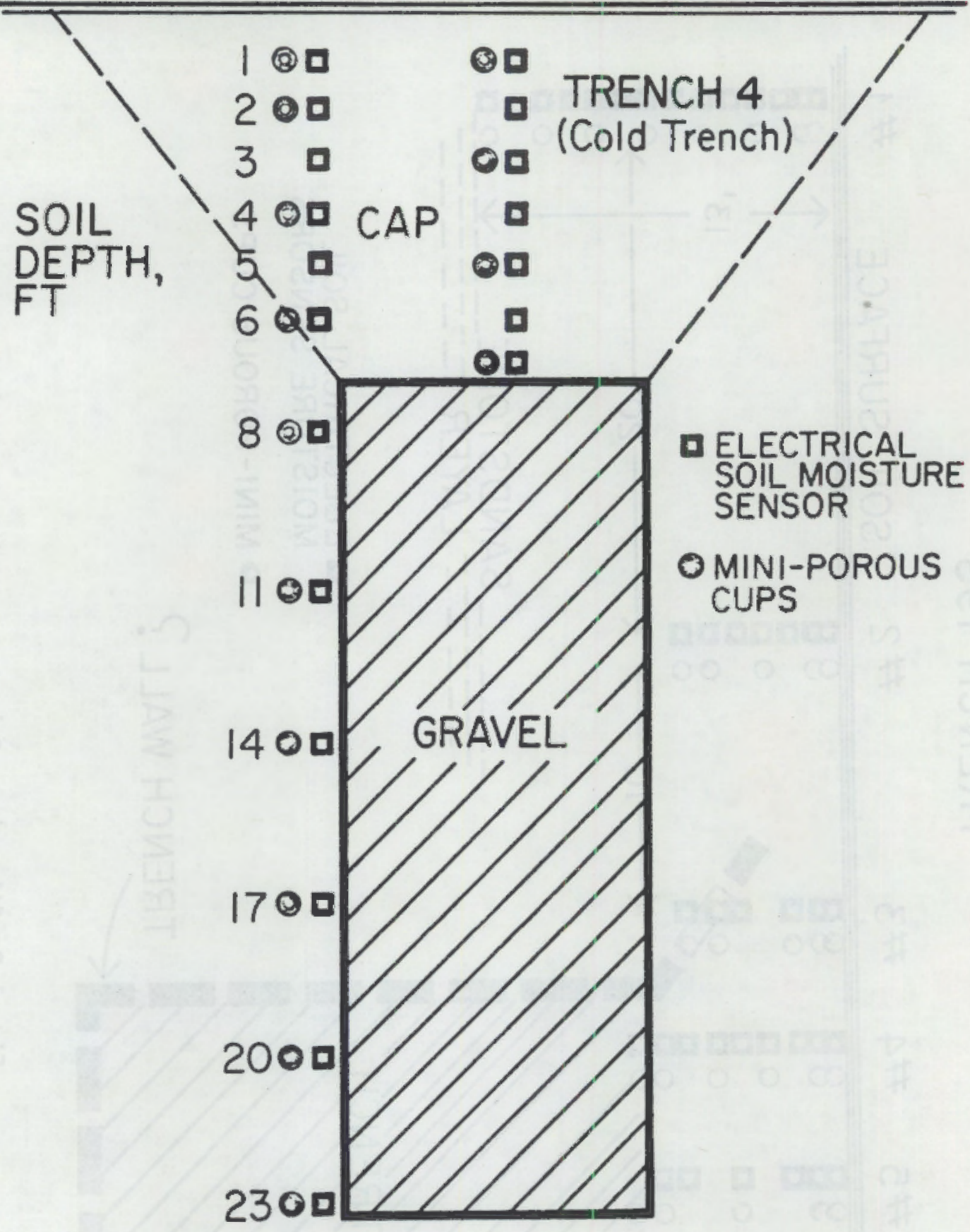

Fig. 2 -Profile view of instrumentation of the experimental trench, section T4. 

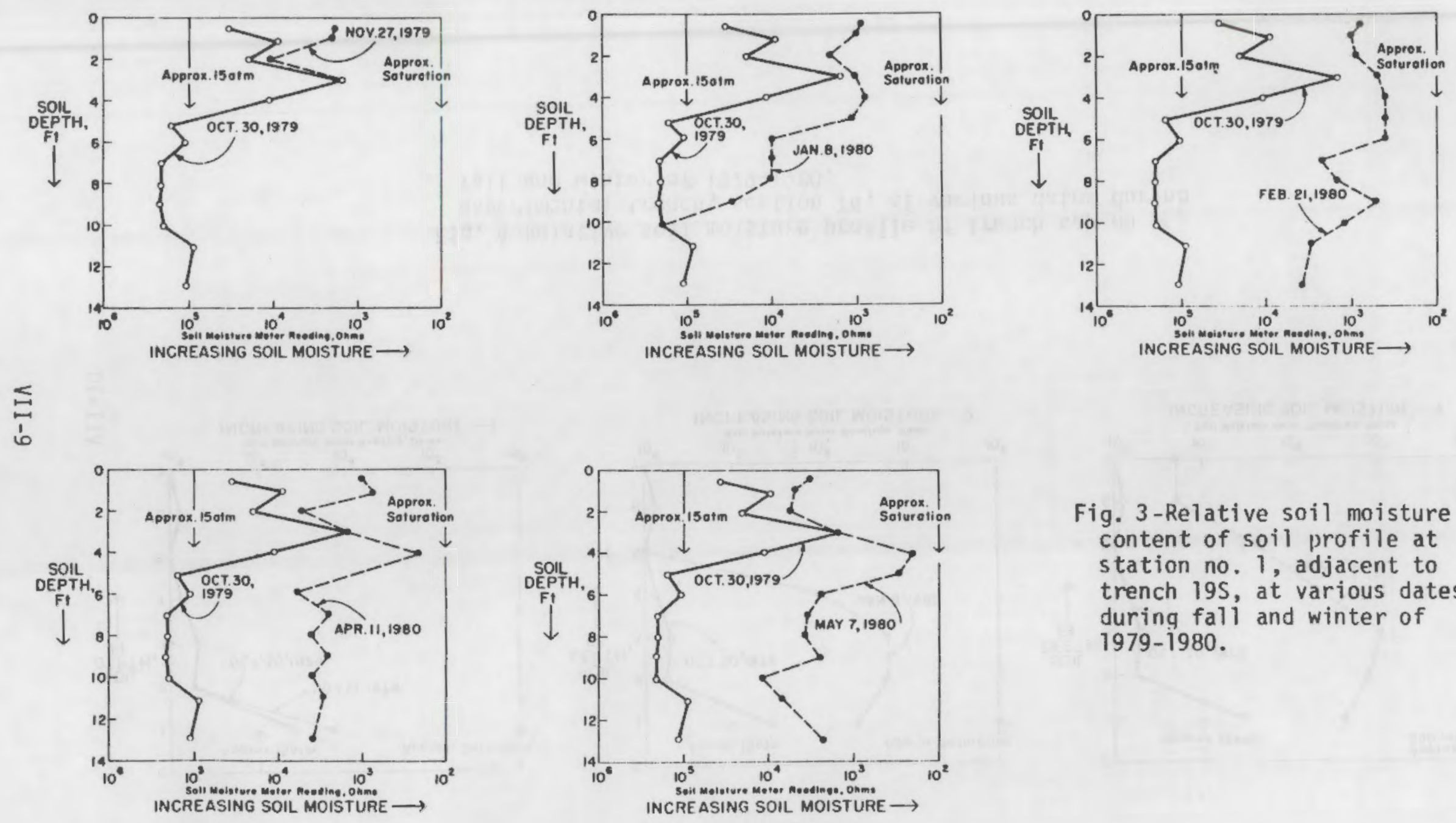

Fig. 3-Relative soil moisture content of soil profile at station no. 1, adjacent to trench 195, at various dates during fall and winter of 1979-1980. 

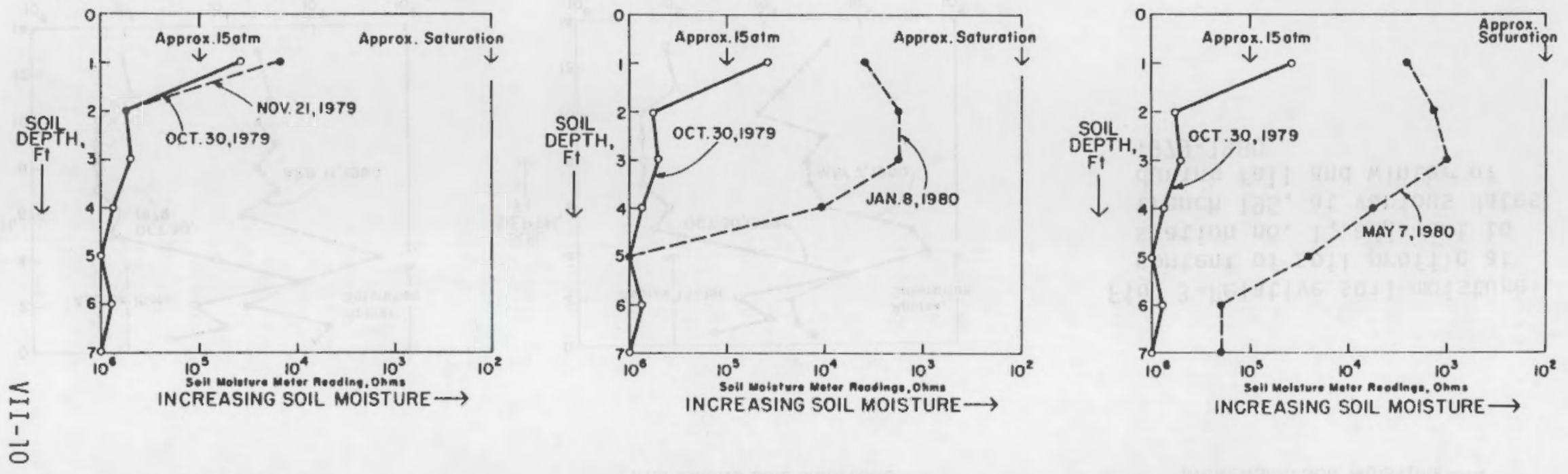

Fig. 4-Relative soil moisture profile of trench cap on experimental trench, section T4, at various dates durina fal1 and winter of 1979-1980. 


\section{SECTION VIII}

THE ROLE OF VEGETATION ON SOIL MOISTURE STATUS AND RADIDNUCLIDE MOVEMENT AT MAXEY FLATS

$$
\text { University of California, Los Angeles }
$$

Division of Environmental Biology

Laboratory of Nuclear Medicine and Radiation Biology 
THE ROLE OF VEGETATION ON SOII MOISTURE STATUS

AND RADIONUCLIDE MOVEMENT AT MAXEY FLATS

\author{
A. Wallace, E. M. Romney and D. J. Herman \\ Division of Environmental Biology \\ Laboratory of Nuclear Medicine and Radiation Biology \\ University of California Los Angeles
}

ABSTRACT

The objective of the studies is to provide information which can result in the management of vegetation cover that will result in minimal percolation of water into trenches at Maxey Flats. It is intended to accomplish this by maximizing the evapotranspiration while at the same time keeping radionuclide uptake by plants within acceptable limits and soil erosion minimal. It is recognized that certain tradeoffs are involved among evapotranspiration, surface runoff, infiltration leading to moderate percolation, some of which may also be lost by runoff after seepage fram lower horizons, and radionuclide uptake and translocation. For example, maximum evapotranspiration may coincide with a relatively high level of radionuclide uptake and a very dense vegetation cover may inhibit surface runoff which in turn could increase infiltration and percolation into trenches. A thorough understanding of these factors and their interrelationships can lead to changes in vegetation management. that would result in improvement in the stability and radionuclide contaiment of the Maxey Flats site. Costs to achieve the improvement should be no more than present costs. The onsite vegetation studies were planned to include planting of the experimental trench caps with different plant species to determine their effectiveness relative to the above factors. Plants were started in a Morehead State University greenhouse and are now planted in the field. The addition of an experimental program using 
simple lysimeters that would simulate trench backfill with plant cover is being considered. This will be a more direct means of assessing the potential role of vegetation in the water management at Maxey Flats than is possible from extrapolation of information from the literature and the mass balance studies conducted by Kentucky at the site. Other studies include evaluation of possible contribution of the present ground cover to radionuclide transport. Gamma spectrometry indicates very little ${ }^{137} \mathrm{Cs}$ (less than $3 \mathrm{pCi} / \mathrm{g}$ for some plant samples) and, most surprisingly, no measurable quantities of ${ }^{60} \mathrm{Co}$. Radiochemical analysis

for ${ }^{90} \mathrm{Sr}$ indicates thus far very little accumulation above background (5 $\mathrm{pCi} / \mathrm{g}$ in one sample). Also included in the studies are glasshouse experiments using soil fram the site. These last experiments are designed to obtain information to improve the vegetation oover through management of soil fertility.

\section{INIRODUCTION}

Vegetation can have at least seven major and minor effects which relate to the problems associated with Maxey Flats. The order presented is not necessarily that of relative importance.

1. Plants, especially those with tall luxuriant vegetation and deep roots, can increase the evapotranspiration loss of water from soil and, as a result, could sufficiently dry out soil enough to decrease the amount of water fram rains that percolates beyond the root zone and possibly into trenches.

2. Plants, especially when sufficiently deep rooted, can take up buried radionuclides which could result in their further dissemination 
into the environment; if favorable conditions exist in trenches, roots may penetrate deeply into them and mobilize radionuclides.

3. Vegetation can decrease the amount of soil erosion which results from high intensity stons and decrease associated radionuclide movement.

4. Vegetation could intercept a portion of the rain on leaf surfaces, again the amount depending both upon the characteristics of the rainfall of a particular stom and upon the type of vegetation. This water could evaporate following the storm without reaching the soil.

5. A heavy cover of vegetation could decrease surface runoff because of the length of time that water can be held up by the plants. This in turn would increase the probability of infiltration into the soil.

6. Decaying plant roots may form channels through which moisture could penetrate to lower soil depths and into trenches.

7. Onganic matter resulting from vegetation, such as litter on the surface and decayed organic matter in the soil, can change runoff, infiltration, and evaporation characteristics.

The objective of the onsite studies being made by our group is to obtain information that will make possible the management of the vegetation of the site in a manner that will maximize the desirable vegetation characteristics for a low level waste burial site and, at the same time, minimize those that are undesirable. Desirable characteristics are those that will result in minimal downward percolation of water into the soil profile and at the same time keep radionuclide uptake by plants within acceptable limits and soil erosion minimal. 
RESULTS TO DATE

The studies are in the early stages with most results being preliminary. Sufficient data are available, however, to help plan future investigations.

(a). Meteorological records for the Maxey Flats site or near the site have been evaluated. A five-year rainfall record for a site near Maxey Flats gave a range of fram 38 to 61 inches per year with a mean of near 51 inches. The coefficient of variation was $20 \%$ for the 5 years. Fram this relatively wide range for just 5 years, it can be predicted that important consequences can result from extremes, both dry and wet, in which trench caps may dry excessively with maximum vegetation cover or in which excessive runoff with erosion and percolation can result. Additional records are to be searched to ascertain if wider extremes are experienced so that any needed protection measures against excessive drought or excessive moisture can be planned.

(b). The best literature data available to date for evapotranspiration near Maxey Flats is that of van Bavel (1961) for Ohio and this was determined by lysimeter and for a meadow. Those data showed an annual mean of 0.090 inches of evapotranspiration/day which totals about 33 inches $(83 \mathrm{~cm})$ for a year. This is a possible maximum for Maxey Flats. Todd (1970) gave total evaporation for a free water surface for a year for the eastern Kentucky area as about 35 inches. Shaw (1964) showed data for Iowa giving evapotranspiration as upward of $80 \%$ of that of a free water surface for uncut vegetation. This would amount to 28 inches for a year if applied to Maxey Flats. This also is a possible maximum for Maxey Flats, although the 33 inches mentioned above should be possible 
with full ground cover. In the mowed condition the evapotranspiration would drop to about 11 inches per year (Shaw, 1964). The exact level of evapotranspiration for the present vegetation at Maxey Flats is unknown, but since the vegetation is relatively sparse and mowed, it may be possible to increase the evapotranspiration at Maxey Flats by several inches per year in most years, depending on amount and distribution of rainfall, with different vegetational management. Increases in evapotranspiration proportionately decrease the amount of water percolating into trenches. Studies are focused on means to increase evapotranspiration.

The evapotranspiration data that have been obtained from the literature have been used with rainfall data fran Farmers, Kentucky near the site and free water surface evaporation data to make estimates which can guide future studies which will be made in attempts to improve the amount of evapotranspiration and decrease the erosion from the site. our purpose is other than merely determining the residual water for percolation, but rather to show that it is possible to manage vegetation to decrease the residual water for percolation into trenches. It is apparent, however, that the information will be incomplete until some lysimeter and/or similar studies are made to accurately measure evapotranspiration.

(c). Stable element tracers have been placed into caps of the Experimental Trench at Maxey Flats and different plant species (alfalfa, lespedeza, crownvetch, clover, and fescue) have been planted on the caps for the purpose of measuring depth of rooting of the various plant species which are candidates for vegetation cover. The studies being made in 1980 are essential to evaluation of the various tradeoffs involving radionuclide uptake and water use. Results will not be available until later 
in the year as plants need to grow and analyses have to be made periodically. Future experiments to establish the merit of deep-rooting plants will be planned as soon as results fram this preliminary study are available.

(d). Plantings on-site are planned, but not yet made, for the purpose of comparing radionuclide uptake for deep-rooted plants with that of the present ground cover. The purpose is to provide information concerning the tradeoff of increased depth of rooting (with increased evapotranspiration) and increased radionuclide uptake. This will be an important complement to the above trace element study and to any future lysimeter study. The species alfalfa and fescue will be planted in groups and, periodically, the radionuclide concentrations of the above ground parts will be determined to ascertain if roots have contacted buried trenches.

(e). Partially completed radiometric and radiochemical analyses of sarmples of grass from the site indicate small quantities of ${ }^{137} \mathrm{Cs}$ and ${ }^{90} \mathrm{Sr}$ in some (less. than $5 \mathrm{pCi} / \mathrm{gram}$ ) and world-wide fallout quantities in others. In none of the samples counted thus far (about 40), has ${ }^{60} \mathrm{Co}$ been detected. This observation is surprising and requires further study because of the relative abundance of ${ }^{60} \mathrm{Co}$ in soils and waters from the site and off site found in studies of other investigators. Differential depth of rcoting may be involved. If ${ }^{60} \mathrm{Co}$ is available, plant uptake is usually expected.

The radiometric analyses are being made with a $3 \times 3 " \mathrm{NaI}$ (TI) crystal in conjunction with a 4000 channel analyzer. In most cases 80-100 grams of plant are placed in a tea hat that fits around the crystal. The samples are counted to $\pm 5 \%$ at the $95 \%$ confidence level. 
(f). Studies of Schulz detailed elsewhere in this report have indicated elevated quantities of $\mathrm{H}^{3}$ in soil profiles with depth gradients which vary fram profile to profile. These results point to the need for detemining to what extent plants are serving as a pathway for exit of $\mathrm{H}^{3}$ from the site. This could be the major pathway and its magnitude will be determined. Appropriate analyses are to be made this summer.

(g). Glasshouse studies of soil from Maxey Flats have been made to ascertain fertility requirements of vegetation cover of a monocot crop (grass) and a dicot crop (legumes were used). Maximum yields were obtained with $200 \mathrm{ppm}$ nitrogen and $100 \mathrm{ppm}$ each of phosphorus and potassium. Liming and potassium were critical for the alfalfa but not for the monocot. Phosphorus was more important for the grass.

Specific rates of fertilization which will give vegetative growth that will maximize evapotranspiration and minimize erosion and deep water percolation are being determined in these studies.

\section{REFERENCES}

Shaw, R. H. 1964. Prediction of soil moisture under meadow. Agron. Jour. 56:320-324.

Todd, D. K., ed. 1970. The Water Encyclopedia (Syosset, N.Y.: Water Information Center, 558 pages.

VanBavel, C. H. M. 1961. Lysimetric measurements of evapotranspiration rates in the eastern United States. Soil Sci. Soc. Aner. Proc. 25:138-141. 
SECTION IX

\section{TRENCH CAP AND TRACER STUDIES}

University of Arizona

Tucson, Arizona 


\section{TRENCH CAP AND TRACER STUDIES}

\section{E. A. Nowatzki, G. M. Thompson, and M. E. Wacks University of Arizona \\ Tucson, Arizona}

INTRODUCTION

Water infiltration problems in the trenches at Maxey Flats resulted in the processing of large volumes of trench leachate. It was not clear whether the infiltration was through the trench caps or due to subsurface flow. Poor surface water management in the past and lack of definitive results from the United States Geological Survey well projects confused the data interpretation. A program of trench capping evaluation coupled with the use of tracers (nonradioactive) was proposed as part of the overall experimental trench evaluation program at Maxey Flats.

The University of Arizona's contribution to the slit trench experiment at Maxey Flats consisted of design of the trench caps and the methodology for tracing water migration into and out of the slit trench complex. The original trench cap designs were modified considerably due to weather-forced delays and the need to finish the construction work. As a result, only three cap methodologies were employed. These were:

a. Clay underlain with Hypalon

b. Clay underlain with Mirafi coated with Flintkote

c. Clay alone

\section{TRENCH CAP DESIGN PARAMETERS}

A general trench cap design is shown in Fig. 1. This design provides a cap-drainage system which prevents surface water seepage into the trench by:

a. Providing for its quick removal by drainage;

b. Being strong enough structurally to resist cracking when underlying materials consolidate.

For the Maxey Flats experiments, the compaction characteristics of two different soils, one on- and the other off-site, were determined under two different compactive energies. A falling head permeability test performed on soil compacted to these specifications in the laboratory provided a value 
of Darcy permeability coefficient of approximately $7 \times 10^{-8} \mathrm{~cm} / \mathrm{sec}$, well within the range of soil drainage properties classified as "practically impervious."

In order to test the ability of the caps to halt surface water migration into the trenches, a system of tracers was utilized in the caps, trenches, and on the surface near the slit trenches. A variety of tracers was incorporated into the trench experiment at Maxey Flats as a means to determine water pathways through the trench and surrounding area. Sodium benzoate and several fluorinated benzoic acid derivatives were used in the trench cap and on the ground surface to monitor movement of surface water into the trenches. Sodium bromide was placed in the bottom of four of the five trenches to trace movement of water from the trench bottoms into the groundwater. The names of the compounds, the amount used, and the location of the tracers are indicated on Fig. 2 .

The sodium bromide and the sodium benzoate were applied to the trenches in the dry solid form. The fluorinated tracers were each dissolved in approximately four liters of ethanol and sprayed on the ground with a standard tree sprayer. Spraying appeared to be the only reasonable means of distributing small amounts of tracer evenly over the cap surface.

Fluorocarbon tracers dispensed from permeation tubes were considered in the original work plan as a means of tracing water movement out of the trenches, but this plan was abandoned when it was later determined that the fluorocarbons would be transported largely through the unsaturated zone by gaseous diffusion. Misleading results would be obtained if the appearance of the fluorocarbon in monitoring wells was assumed to indicate groundwater movement.

\section{SAMPLING DEVICES}

Water samples were collected from the trench bottoms using standard porous cup samplers supplied by Soil Test Incorporated, Goleta, California. The sampling device is shown schematically in Fig. 3. These samplers were placed in each trench, one in the middle and one at each end. The samplers are identified in Fig. 2 in each trench* with the letters $a, b$, and $c$. No

\footnotetext{
*Unfortunately, the samplers in segment 1 of the trench were installed incorrectly and this segment is sampled through the two sumps.
} 
samplers were placed in the ground around the periphery of the trenches as was originally planned due to the difficulty of augering in the area. Holes for groundwater sampling around the trenches will be considered later. This is a vital part of the completion of the experiments already in place.

MONITORING RESULTS

Water samples were collected from each of the sampling points in the trenches on December 27, 1979 and again on March 19, 1980. The samples were each analyzed for all of the organic tracers using high performance liquid chromatography. Results are presented in Table I. No tracer was detectable in any of the samples. The threshold of detection should be approximately $5 \mathrm{ppb}$ for these tracers; however, due to interference, the detection limits in Table I were higher. We are now able to remove these interferences and achieve the expected detection limits. These results suggest that little or no water has infiltrated into the trenches through the caps.

In order to get the maximum information from this in-place experiment, it is recommended that:

a. A series of wells be placed away from the slit trenches to detect subsurface movement of water through the trenches.

b. Water samples from the trenches continue to be analyzed (on a quarterly basis) for tracers from the caps and ground surface until failure is detected or for at least two additional years.

c. Trench caps and drainage systems be maintained as designed. 
Table I Maxey Flats Test Irench-Results of Tracer Monitoring for Samples Obtained December 28, 1979 and March 19, 1980

First Sampling - December 28, 1979

\begin{tabular}{|c|c|c|c|c|}
\hline $\begin{array}{l}\text { Section of } \\
\text { Trench No. }\end{array}$ & "Sampler No. & $\begin{array}{c}\text { Tracer } \\
\text { Used }\end{array}$ & $\begin{array}{l}\text { Amount of Tracer } \\
\text { Detected (ppm) }\end{array}$ & $\begin{array}{l}\text { Detection } \\
\text { Limit (ppm) }\end{array}$ \\
\hline 1 & $s-1$ & $\mathrm{NaB}$ & $t+$ & 0.5 \\
\hline 1 & $s-2$ & $\mathrm{NaB}$ & tt & 0.5 \\
\hline 2 & 1 & OFB & t† & 0.02 \\
\hline 2 & 2 & OFB & $+t$ & 0.02 \\
\hline 2 & 3 & OFB & t† & 0.02 \\
\hline 3 & 1 & $\mathrm{NaB}$ & tt & 0.5 \\
\hline 3 & 2 & $\mathrm{NaB}$ & t† & 0.5 \\
\hline 3 & 3 & $\mathrm{NaB}$ & t† & 0.5 \\
\hline 4 & 1 & PFB & $t+$ & 0.5 \\
\hline 4 & 2 & PFB & $t+$ & 0.5 \\
\hline 5 & 2 & $\mathrm{NaB}$ & tt & 0.5 \\
\hline 5 & 3 & $\mathrm{NaB}$ & $+\dagger$ & 0.5 \\
\hline
\end{tabular}

\section{Second}

Sampling - March 19, 1980

\begin{tabular}{lclll}
\hline 1 & $\mathrm{~S}-1$ & $\mathrm{NaB}$ & $+\dagger$ & 0.5 \\
1 & $\mathrm{~S}-2$ & $\mathrm{NaB}$ & $+\dagger$ & 0.5 \\
2 & 1 & OFB & $+\dagger$ & 0.02 \\
2 & 2 & OFB & $+\dagger$ & 0.02 \\
2 & 3 & OFB & $+\dagger$ & 0.02 \\
3 & 1 & $\mathrm{NaB}$ & $+\dagger$ & 0.5 \\
3 & 2 & $\mathrm{NaB}$ & $+\dagger$ & 0.5 \\
3 & 3 & $\mathrm{NaB}$ & $+\dagger$ & 0.5 \\
4 & 1 & $\mathrm{PFB}$ & $+\dagger$ & 0.5 \\
4 & 2 & $\mathrm{PFB}$ & $\dagger+$ & 0.5 \\
5 & 2 & $\mathrm{NaB}$ & $+\dagger$ & 0.5 \\
5 & 3 & $\mathrm{NaB}$ & $+\dagger$ & 0.5 \\
\hline
\end{tabular}

*Note: Some porous cup samplers could not be used for obtaining samples. In such cases the sumps were used to obtain samples. This is denoted by $\mathrm{S}-\mathrm{n}$.

${ }^{\dagger}$ Abbreviations: PFB $\equiv$ Pentafluorobenzoic Acid; NaB $\equiv$ Sodium Benzoate;

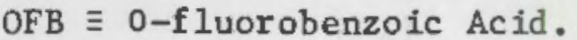
t+No tracer detected. 


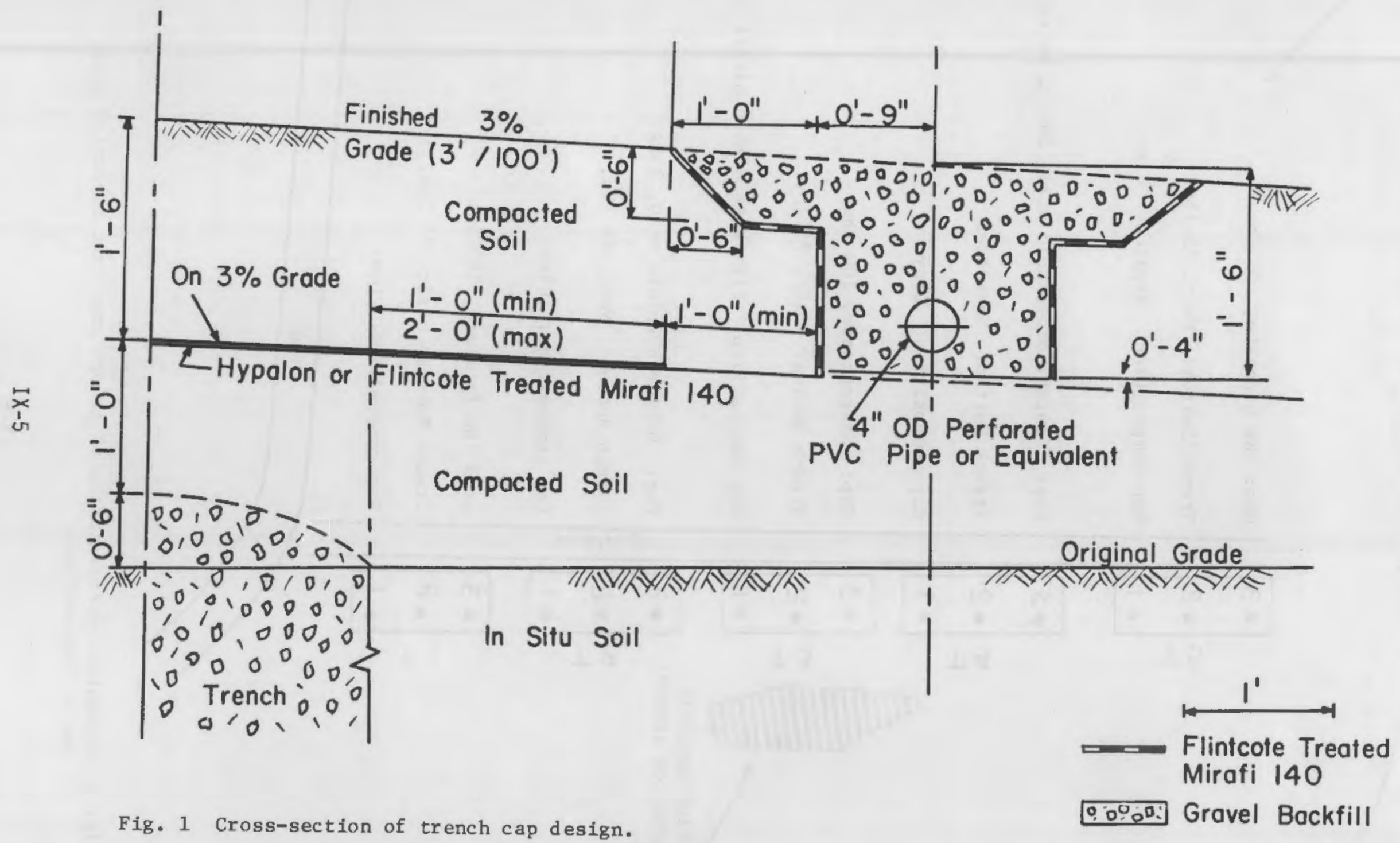




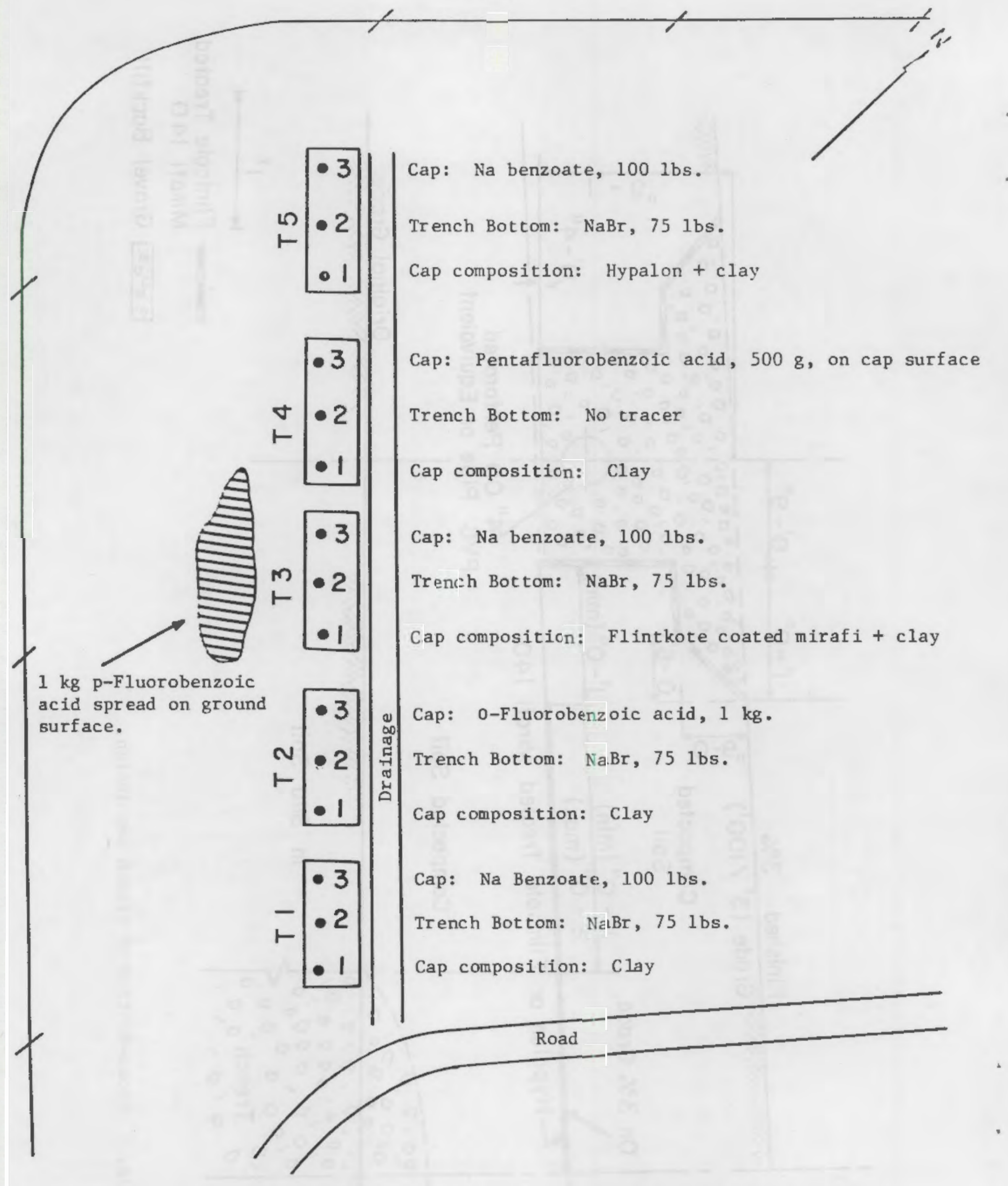

Fig. 2 Schematic representation of trench area (not to scale) with tracer information. 


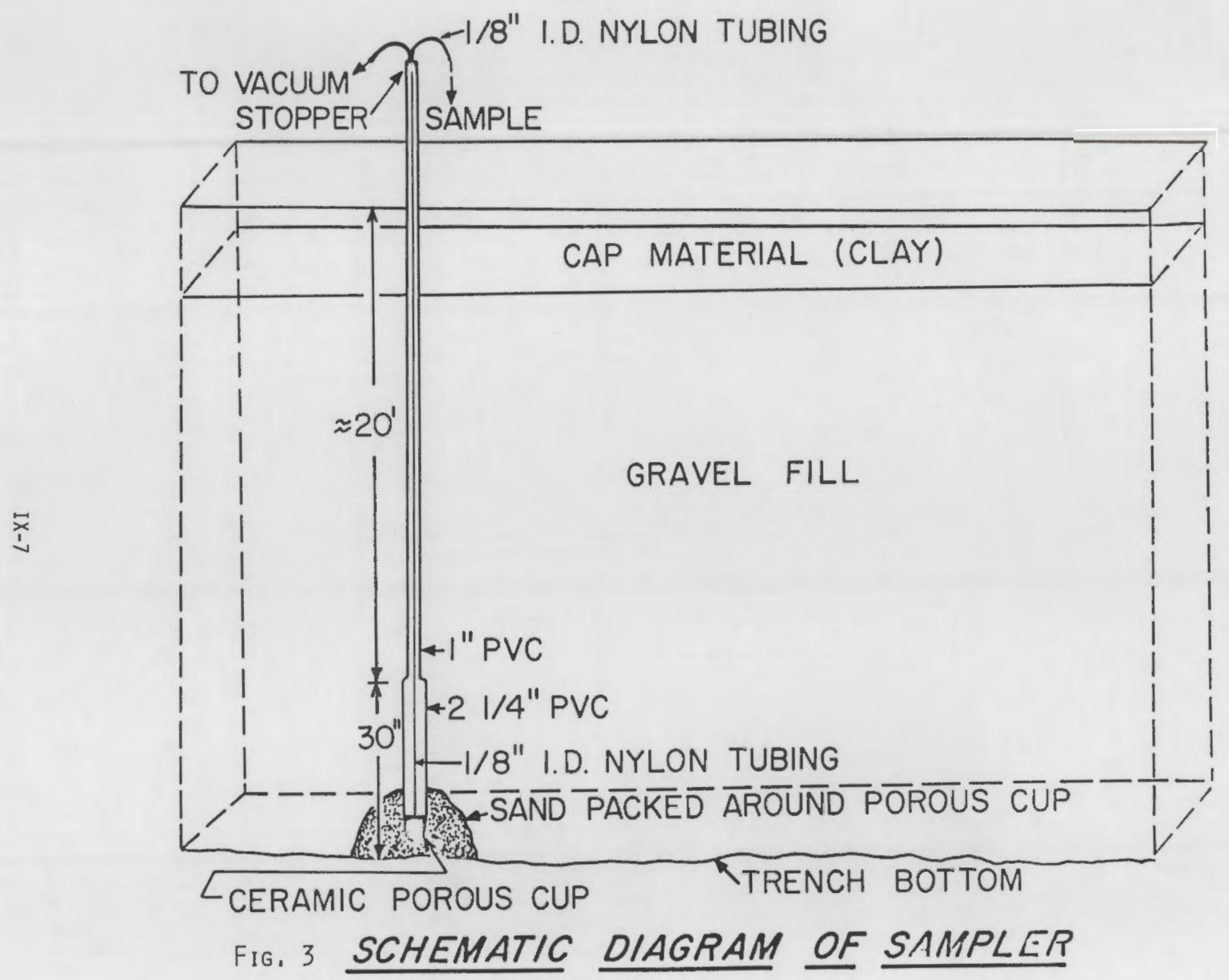



SECTION $X$

\author{
RESEARCH AT THE WEST VALLEY, NEW YORK \\ LOW-LEVEL RADIOACTIVE WASTE BURIAL SITE
}

\author{
New York State Geological Survey \\ State Museum, Science Service \\ New York State Education Department
}




\title{
RESEARCH AT THE WEST VALLEY, NEW YORK \\ LOW-LEVEL RADIOACTIVE WASTE BURIAL SITE
}

\author{
Henry H. Bailey \\ New York State Geological Survey \\ State Museum, Science Service \\ New York State Education Department
}

The Western New York Nuclear Service Center, familiarly known as West valley, is the site of the only New York State licensed low-level radioactive waste burial facility. This site, inactive since 1975, is located in Western New York, some 30 miles southeast of Buffalo. Also located at West Valley is the only commercial nuclear fuel reprocessing plant that ever operated in the United States. This plant has been out of operation since 1972. Associated with the now idle reprocessing plant are two steel tanks containing a total of some 612,000 gallons of high-level liquid radioactive waste and a Nuclear Regulatory Commission (NRC) licensed high-level radioactive waste burial site which is located adjacent to the low-level waste burial area.

West Valley, like Maxey Flats, is located in the Appalachian uplands, although on their northern fringe, and shares with Maxey Flats a rather humid climate. Precipitation at West Valley is generally about 40 inches per year. Some 10 inches of this precipitation falls in the form of snow. Applying the rough conversion factor of one inch of precipitation equalling 10 inches of snow, it can be seen that a typical West Valley winter has some 8 feet of snowfall. Such weather makes for trying winter field conditions.

State agency research on the low-level burial site began in 1975 . Funding for this research came first from the U. S. Environmental Protection Agency (EPA), then from EPA and the NRC jointly, and is now funded by the NRC exclusively. The New York State Geological Survey has worked with the United States Geological Survey (USGS) in cooperative programs at West Valley and the USGS has also carried out investigations there utilizing internal funding sources.

It is a fair question to ask why a State Geological Survey is acting as the lead state agency in research at a low-level waste burial site. In 
order to answer that question, we must consider the specific concerns to which research at West Valley is being addressed. What is the nature of the burial site? The burial trenches at West Valley are dug into material deposited by a glacier and consist of a dense clayey silt till in which lenses of silt, sand, and gravel are sparsely distributed. The glacial deposits of the site are being acted upon by the natural processes of erosion with active stream downcutting and associated mass slumping, or landsliding, occurring near the site. In time these processes can be expected to impinge upon the burial site and affect its containment integrity. Problems involving the entry of water into the trenches with a rise in trench water levels have been encountered which necessitated the pump-out of trench water. Is this water infiltrating into the trenches through groundwater pathways? More disturbing, certainly, is the obverse of that question: is trench water escaping from the trenches by groundwater pathways? What is the trenches' capacity to isolate the waste from groundwater? In short, what is the groundwater regime of the burial area? Another cause of concern was whether or not radionuclides from the burial site are finding pathways offsite either in surface water or entrained with sediments being carried by the surface water.

From the foregoing it can be seen that the concerns to be addressed by research at west Valley generally contain strong geologic elements. The nature of the burial material and its vertical and lateral relationships fall into the realm of glacial geology and stratigraphy. Stream erosion and mass wasting are the province of the geomorphologist. The question of containment integrity falls to the engineering geologist. The groundwater regime of the site is the concern of the geohydrologist. Stream flow and sediment transport are hydrologic and geomorphologic concerns. In such a situation, I feel it logical that a geological survey is a reasonable choice for research responsibility. One area of the research at West valley is certainly not geological in nature. That is the identification of the presence and concentration of radionuclides in water and soil samples, and radiochemically oriented research in general at west valley. This work has been handled by the Radiological Sciences Laboratory of the New York State Health Department.

What have we found out in our five years of research? First and foremost is that the integrity of the trenches as containers is quite reasonable. 
The dense clayey silt till in which they are dug is of very low permeability, on the order of $2 \times 10^{-8} \mathrm{~cm} / \mathrm{sec}$ vertically and $56 \times 10^{-8} \mathrm{~cm} / \mathrm{sec}$ horizontally. Groundwater movement in the till, such as it is, is vertically downward. No indications of substantial lateral movement of groundwater into the trenches or of trench water outwards have been found. The silt, sand, and gravel lenses, characterized by rolled, distorted bedding were determined to have been emplaced mechanically with the till by the glacier and are not laterally extensive sedimentary layers which might act as groundwater pathways. The USGS performed subtrench soil sample borings which showed migration of tritium to a maximum depth of $3.2 \mathrm{~m}$ below trench floor, while ${ }^{14} \mathrm{C}$ was found as deep as $0.6 \mathrm{~m}$ below trench floor. The research related to the geohydrology of the low-level burial site indicated that water entry into the burial trenches is a result of the vertical percolation of precipitation through the capping material. The trench cap material is permeable to gas and our research has documented that mildly radioactive gases, primarily tritiated methane and other radiocarbon and tritiated gases, are present in the waste-generated gases. Baseline geomorphic studies have been completed and are now being followed up by investigations which will yield erosion rates. These landformerosion studies will permit us to make our best prediction of the time remaining before natural erosive processes threaten the burial site's containment integrity. Our hydrologic program is continuing. Surface drainage from the low-level burial site has been monitored for radionuclide transport at four sampling stations which cover virtually all drainage from the low-level burial site. Radionuclide measurements for water and entrained sediments at three of these stations have been within one order of magnitude of background levels. Somewhat higher levels have been measured at the fourth station where, unfortunately, the watercourse sampled has a mix of drainages from other areas in addition to that from the low-level site.

I have attempted to touch upon what we see as the most important results of research at the low-level burial site at West valley to date. I would like to return to one point, that of trench capping and its effectiveness in furnishing isolation for the burial waste from surface water. The trench caps at West valley are constructed from the dense glacial till which was excavated in trench construction and which has been compacted and mounded. 
Experience has shown that although the caps are relatively impermeable for a few years, they eventually dry and with drying undergo a slight loss in volume. This results in the formation of tensional cracks. These cracks are similar to the closed fractures found in the undisturbed till and which have been observed to extend to a depth of $15 \mathrm{ft}$ in a research trench. These cracks, with time, form conduits for surface water to enter the trenches. The gross permeability of the trench caps has been found to be very sensitive to climatic change, in particular to long dry periods. The effectiveness of the cracks as water pathways into the trenches appears to be further increased by what is interpreted as the decay and compaction of buried waste. This volume reduction allows the slumping of cap material and this produces surface depressions which can channel surface water into the cracks. Maintenance of the caps by compaction and filling, where necessary, to el iminate the cracks and depressions apparently is effective in reducing water entry. I should like to emphasize, however, that regular maintenance of the trench caps at West Valley will have to continue as long as the native burial soil is used as the sole capping material.

Research to date has been focused on the low-level radioactive waste burial site. With NRC funding, the scope of research at West Valley has been expanded to include the entire site. The hydrologic and geohydrologic regimes of the area north of the fuel reprocessing plant, in which the highlevel liquid radioactive waste tanks are located, are not well known. Indeed, the geohydrologic regime in that area appears to be substantially different than that of the area of the low-level trenches. The geohydrology of the NRC-licensed high-level burial area is inferred to be similar to that of the low-level burial area; they are after all located adjacent to each other, but to date it has not been investigated. A program to investigate the geohydrology will begin this fall. The amplification of the study area has resulted in a redesign of the hydrologic investigation program. Geomorphic studies in progress have site-wide applicability and will be continued. Current plans call for the completion of field investigations within three years. 


\section{SECTION XI}

PRELIMINARY HYDROGEOLOGIC INVESTIGATION

OF THE MAXEY FLATS RADIOACTIVE WASTE BURIAL SITE

FLEMING COUNTY, KENTUCKY

U. S. Geological Survey 


\section{PRELIMINARY HYDROGEOLOGIC INVESTIGATION \\ OF THE MAXEY FLATS RADIOACTIVE WASTE BURIAL SITE \\ FLEMING COUNTY, KENTUCKY}

Harold H. Zehner

U. S. Geological Survey

Maxey Flats is an isolated plateau in northeastern Kentucky, near the city of Morehead. The radioactive waste burial site is located on the plateau about 300 to 400 feet above the surrounding valleys. Radioactive waste burial at Maxey Flats began in 1963. Completed trenches at the site are about 20 feet deep and occupy an area of about 0.03 square miles. As of January, 1972, approximately 1.2 million curies of by-product material, plus 460 pounds of special nuclear material and 87 thousand pounds of source material, had been buried.

Rocks in the Maxey Flats area are of Mississippian and Late Devonian age including, in descending order, the Nancy and Farmers Members of the Borden Formation, Sunbury, Bedford, and Ohio Shales, and the upper part of the Crab Orchard Formation. The total thickness of these rocks is about 320 feet. A11 radioactive wastes are buried in shale of the Nancy Member.

The shale and sandstone bedrock has poor water-transmitting capability. Wells open to bedrock probably obtain water from very narrow cracks in the rocks. Two zones of water-saturated rocks were found below the top of the plateau, one at depths of 45 to 70 feet, and one at depths of 250 to 350 feet. Other saturated zones may be present.

Most groundwater users obtain water from above bedrock--in weathered shale near ground surface and from gravel deposits near streams. Although some well owners obtain adequate water supplies from their wells, others must obtain additional supplies from cisterns, ponds, and springs. Many springs are at the bases of hills. Water supplying these springs is probably transmitted through near-surface soil and weathered bedrock on the top of hills and rock debris covering the sides of hills.

Mean annual precipitation at nearby Farmers, Kentucky, is about 46 inches. Infiltrating rainfall is temporarily stored in weathered bedrock 
on hilltops and colluvium and soil on hillsides. The water later discharges in springs at the bases of the hills. Base flow in Rock Lick Creek and its tributaries is derived mainly from alluvium in the valleys and the mantle of regolith, colluvium, and soil on adjacent sides and tops of hills. Little is known about the groundwater hydraulics of the area. If movement of dissolved and water-suspended radioactive materials from the burial site were to occur by natural processes, surface and groundwater would be the means of transport.

Well yields are low in all rocks at Maxey Flats, and most groundwater movement is in secondary openings, particularly joints. The groundwater system at Maxey Flats is probably unconfined and recharge occurs by: (a) infiltration of rainfall into the mantle; and (b) vertical unsaturated flow from the regolith at the top of the hill to saturated zones in the Farmers Member and Ohio Shale. Discharge occurs by lateral flow from the mantle and bedrock to the sides of hills or to alluvium in valley bottoms.

A report describing the hydrology of the Maxey Flats area, including the radioactive waste burial site, has been published by the U. S. Geological Survey, Department of the Interior, in cooperation with the U. S. Environmental Protection Agency. Copies of the 100-page report, "Preliminary Hydrologic Investigation of the Maxey Flats Radioactive Waste Burial Site, Fleming County, Kentucky," U. S. Geological Open File Report 79-1329 (Water Resources Investigations) are available for examination at the U. S. Geological Survey, Room 572, Federal Building, Louisville, Kentucky 40202. The report may be purchased from the U. S. Geological Survey Open File Services Section, Branch of Distribution, Box 25425, Federal Center, Denver, Colorado 80225 . 


\section{DISTRIBUTION}

No. of

Copies

OFFSITE

1 A. A. Churm

DOE Patent Division

9800 South Cass Avenue

Argonne, IL 60439

360 NRC Division of Technical Information and Document Control

7920 Norfolk Avenue

Bethesda, MD 20014

2 DOE Technical Information Center

10 Office of Nuclear Regulatory Research

Fuel Cycle and Environmental Research

Division of Safeguards, Fue 1 Cycle and Environmental Research

Mail Stop 1130SS

Washington, D. C. 20555

Harry H. Landon

25 Ed Held

U. S. Nuclear Regulatory Commission

Division of Safeguards and Environmental Research Mail Stop 1130ss

Washington, D. C. 20555

1 A. J. Weiss

Brookhaven Nationa 1 Laboratory Upton, NY 11973

1 K. S. Czyscinski

Brookhaven National Laboratory Upton, NY 11973
No. of

Copies

OFFSITE

1 H. H. Bailey

The University of the State of New York

The State Education Department

New York State Museum and Science Service

Geological Survey

Albany, NY 12234

1 A. Wallace

University of California

Laboratory of Nuclear Medicine and Radiation Biology

900 Veteran Avenue

Los Angeles, CA 90024

1 E. M. Romney

University of California

Laboratory of Nuclear Medicine and Radiation Biology

900 Veteran Avenue

Los Angeles, CA 90024

1 D. J. Herman

University of California

Laboratory of Nuclear Medicine and Radiation Biology

900 Veteran Avenue

Los Angeles, CA 90024

1 R. K. Schulz

University of California

Department of Soils and Plant Nutrition

Berkeley, CA 94720

1 J. Clancy

Dames \& Moore

20 Haarlem Avenue

White Plains, NY 10600 
No. of

Copies

OFFSITE

1

E. Picazo

Dames \& Moore

20 Haarlem Avenue

White Plains, NY 10600

$1 \mathrm{G} . \mathrm{Re}$

Dames \& Moore

20 Haarlem Avenue

White Plains, NY 10600

1 M. Fiskin

Dames \& Moore

20 Haarlem Avenue

White Plains, NY 10600

1 W. L. Polzer

Los Alamos Scientific Laboratory

Environmental Science

P. 0. Box 1663

Los Alamos, NM 87545

1 E. H. Essington

Los Alamos Scientific Laboratory

Environmental Science

P. 0. Box 1663

Los Alamos, NM 87545

1 E. B. Fowler

Los Alamos Scientific Laboratory

Environmental Science

Soils Chemistry and Microbiology

P. 0. Box 1663

Los Alamos, NM 87545

1 J. B. Robertson

U. S. Geological Survey

Office of Radiohydrology

National Center MS 410

Reston, VA 22092

1 H. H. Zehner

U. S. Geological Survey, W.R.D.

Room 572 Federal Building

600 Federal Place

Louisville, KY 40202
No. of

Copies

\section{OFFSITE}

1 E. A. Nowatzki

University of Arizona

Tucson, AZ 85721

1 G. M. Thompson

University of Arizona

Tucson, AZ 85721

1 M. E. Wacks

University of Arizona

Department of Nuclear Engineering

Tucson, AZ 85721

1 R. M. Fry

Division of Hazardous Material and Waste Management

Commonwealth of Kentucky

Department for Natural Resources and Environmental Protection

Pine Hill Plaza

1121 Louisville Road

Frankfort, KY 40601

1 J. E. Razor

Nuclear Engineering $\mathrm{Co}$.

P. 0. Box 146

Morehead, KY 40351

1 D. Clark

Department for Human Resources

Commonwealth of Kentucky

275 East Main Street

Frankfort, KY 40601

\section{ONSITE}

21 L. J. Kirby (5)

J. M. Nielsen

W. R. Wiley

R. W. Perkins (5)

L. C. Schwendiman

N. A. Wogman

Technical Information (5)

Publishing Coordination (2) 



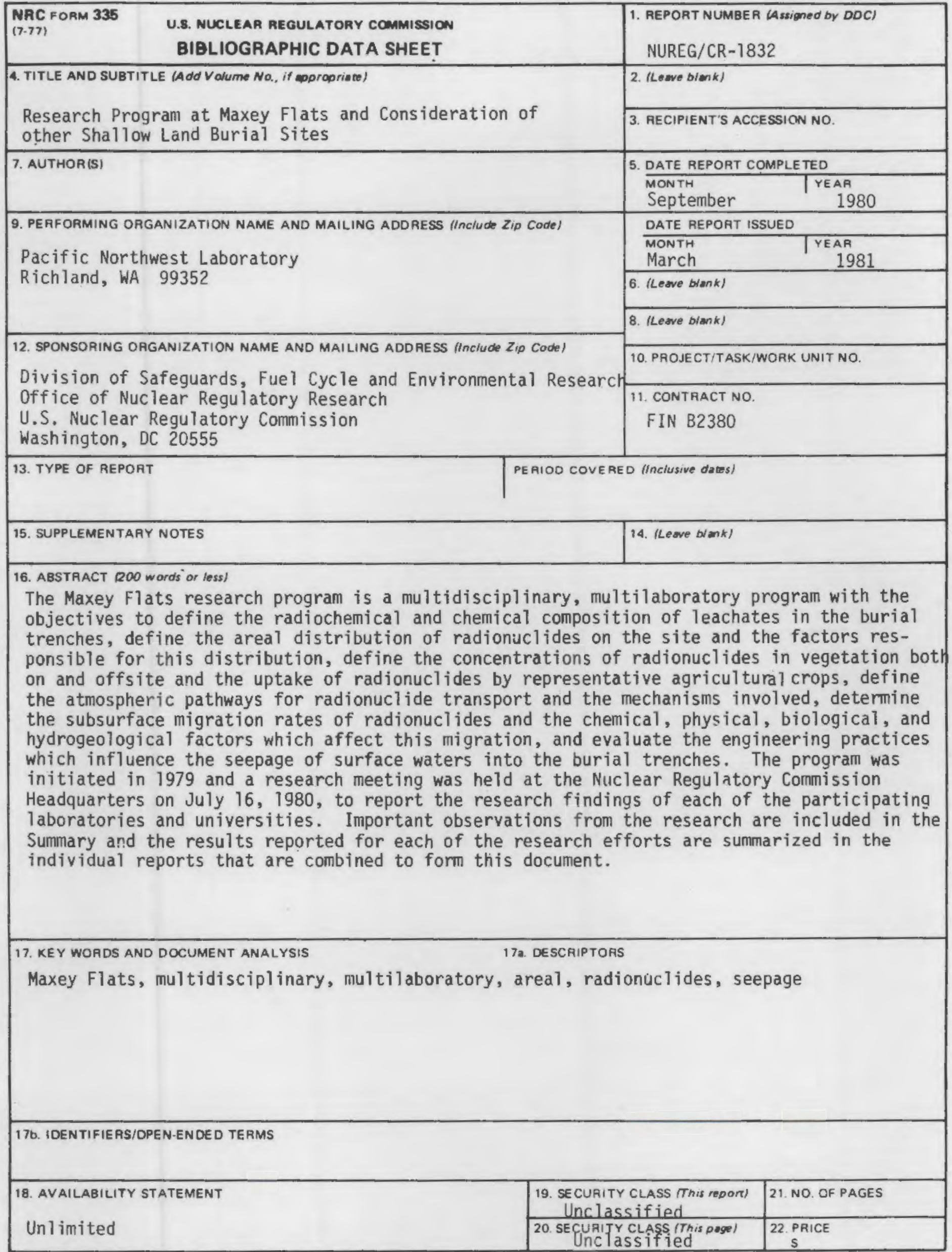




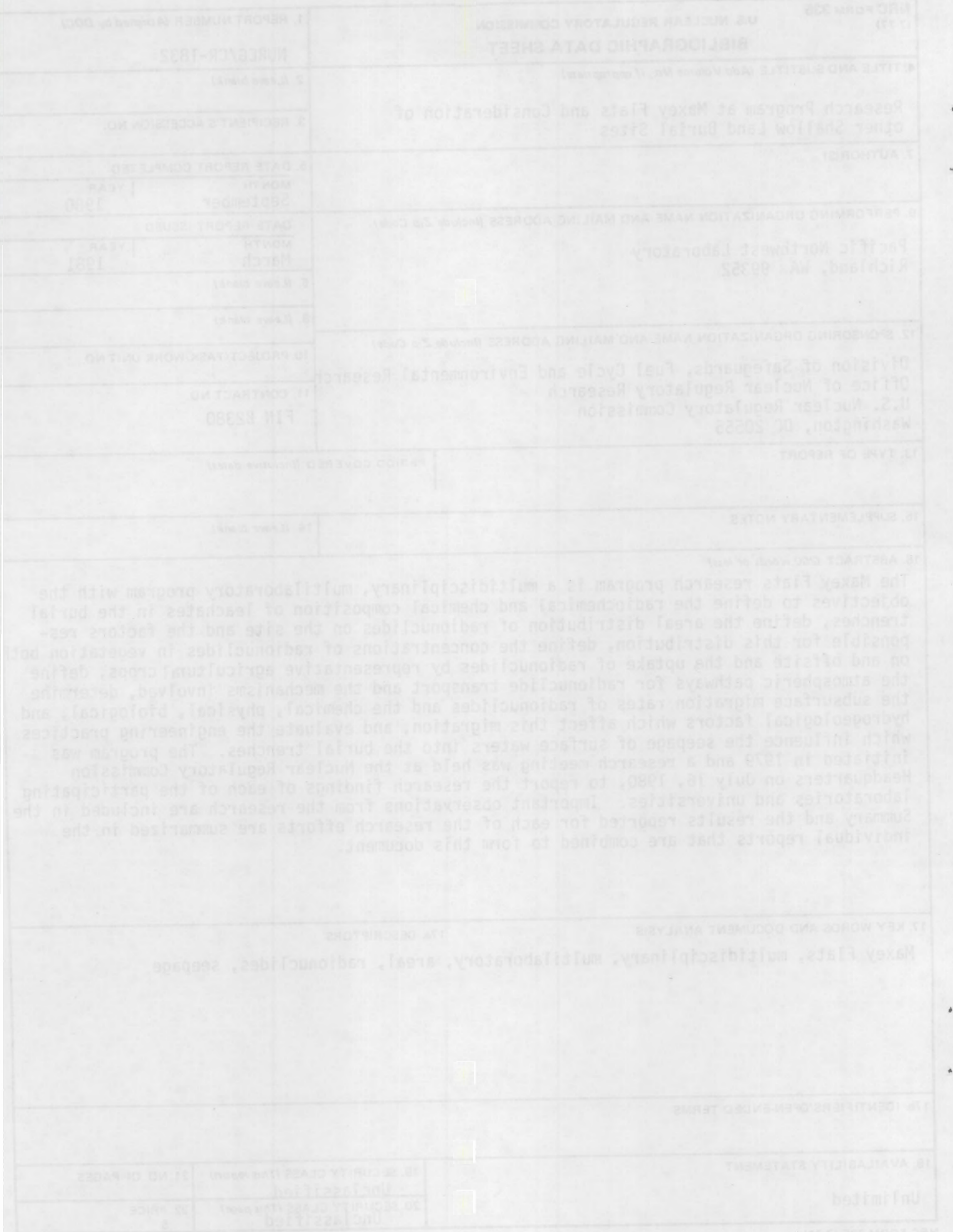

